UNIVERSIDADE DE SÃO PAULO

FACULDADE DE MEDICINA DE RIBEIRÃO PRETO

\title{
PREVALÊNCIA DAS DOENÇAS PERIODONTAIS EM PACIENTES COM DOENÇA ISQUÊMICA CORONARIANA ATEROSCLERÓTICA, EM HOSPITAL UNIVERSITÁRIO.
}

ANA LÚCIA DE AZEVEDO BARILLI

RIBEIRÃO PRETO-SP 


\section{PREVALÊNCIA DAS DOENÇAS PERIODONTAIS EM PACIENTES COM DOENÇA ISQUÊMICA CORONARIANA ATEROSCLERÓTICA, EM HOSPITAL UNIVERSITÁRIO.}

ANA LÚCIA DE AZEVEDO BARILLI

Dissertação apresentada a Faculdade de Medicina de Ribeirão Preto da Universidade de São Paulo, para concorrer ao Título de Mestre, pelo curso de Pós-Graduação do Departamento de Medicina Social - Área de concentração: Saúde na Comunidade.

Orientador: Prof. Dr. Laércio Joel Franco

RIBEIRÃO PRETO-SP 
FICHA CATALOGRÁFICA

Barilli, Ana Lúcia de Azevedo.

Prevalência das Doenças Periodontais em Pacientes com Doença Isquêmica Coronariana Aterosclerótica, em Hospital Universitário. Ribeirão Preto, 2003.

117 p. : il. ; $30 \mathrm{~cm}$

Dissertação de Mestrado, apresentada à Faculdade de Medicina de Ribeirão Preto/USP - Área de concentração: Saúde na comunidade.

Orientador: Franco, Laércio Joel.

1. Doenças Periodontais. 2. Índice Periodontal Comunitário - IPC. 3. Perda de Inserção Periodontal. 


\section{DEDICATÓRIA}

Dedico este trabalho ao meu querido filho, Guilherme, meu precioso "tesouro".

Aos meus pais, pelo carinho e apoio com os quais nos presenteiam.

Aos que comigo compartilham crenças, lutas, confiança, carinho, amizade, parceria e cumplicidade.

À todos que desejam um mundo mais justo, digno e igualitário. 


\section{AGRADECIMENTOS}

Esta pesquisa é fruto do empenho de mentes de muitos pensadores angustiados por melhores condições de saúde do povo brasileiro, incluindo-se aí a esquecida e ausente saúde bucal.

Todos que nela trabalharam, direta e indiretamente, o fizeram amorosamente pela nobre causa de conhecer para poder buscar e implementar ações que dignifiquem e dêem ao nosso cidadão acesso a serviços, conhecimentos e ações, para a conquista de uma melhor qualidade de vida.

Participaram dela muitas pessoas, algumas sugerindo alterações, outras com novas idéias, outras ainda revisando textos e dados, fazendo críticas, dando assistência na área de informática e estatística, algumas ainda com a difícil tarefa de apoio pessoal. Todos foram responsáveis para que esta pesquisa fosse levada a termo, e, para isto, doaram-se com solidariedade, desprendimento e extremada simpatia.

Os seus participantes foram muitos, em diferentes locais, momentos e práticas, porém todos com participação e valor fundamentais e inestimáveis na obtenção dos resultados ora apresentados.

Como locais diretamente envolvidos na coleta das informações tivemos os Ambulatórios de Cardiologia Isquêmica e de Hepatites do Hospital das Clínicas, o Núcleo de Vigilância Epidemiológica do Departamento de Medicina Social; no processamento e análise dos dados estiveram envolvidos o Núcleo de Informática e demais setores do Departamento de Medicina Social. Todos eles estão vinculados à Faculdade de Medicina de Ribeirão Preto da Universidade de São Paulo. Como local indiretamente envolvido tivemos o serviço odontológico da UBDS João Baptista Quartim, da Secretaria Municipal de Saúde de Ribeirão Preto-SP, que permitiu alterações nas escalas dos plantões odontológicos, trocas essas que me permitiram estar nos ambulatórios para proceder ao recrutamento dos pacientes e coleta das informações comportamentais e bucais. Sem a colaboração das pessoas desses diferentes locais, não se obteria os dados aqui demonstrados. Recordá-los e expressar-lhes meus mais profundos agradecimentos, constitui-se prazerosa tarefa e dever de consciência. Ajudaram-me a vencer as dificuldades advindas da escolha pelo tema que permitiria conhecer alguns aspectos da saúde bucal, mesmo em ambiente hospitalar, que normalmente não possui profissional, espaço e tempo dedicado a investigar nível de saúde-doença da cavidade bucal. Aprendi com a convivência com todos, tanto conceitos acadêmicos, como da vivência e do aprimoramento da natureza humana.

Citá-los nominalmente pode resultar, por falha na memória, na omissão de alguém. Assumindo este risco e antecipadamente me desculpando com aqueles que não se sintam lembrados e prestigiados, expresso minha gratidão às seguintes instituições e pessoas: 
Ao Prof. Dr. José Antonio Marin Neto, chefe do Ambulatório de Cardiologia Isquêmica do HCFMRP-USP, pelo interesse, apoio e incentivo ao estudo e por possibilitar o acesso ao ambulatório para coleta dos dados.

Aos Professores Doutores Ana de Lourdes Candolo Martinelli e José Fernando de Castro Figueiredo, responsáveis pelo Ambulatório de Hepatites, do HCFMRP-USP, pelo apoio e por permitir acesso e coleta dos dados no ambulatório sob sua responsabilidade.

Aos Professores Doutores Antônio Ruffino-Neto e José Roberto Tamburús, por aceitarem ser bancas da qualificação e desta dissertação, bem como pelas sugestões feitas.

Aos docentes, médicos e residentes do Ambulatório de Cardiologia Isquêmica, por me proporcionarem espaço e tempo para identificar os pacientes potenciais participantes da pesquisa, em especial ao Dr. Vamberto por sua extremada simpatia nos longos meses de convivência.

Aos docentes, médicos e residentes do Ambulatório de Hepatites, por me proporcionarem espaço e tempo para identificar os pacientes potenciais participantes da pesquisa. Especial agradecimento à Tânia, Assistente Social do HCFMRP-USP, pela gentileza em muito colaborar no recrutamento dos pacientes no Ambulatório de Hepatites.

Aos docentes do Departamento de Medicina Social da FMRP-USP, que produziram conhecimento e provocaram "inquietações" por mais conhecer.

Ao Prof. Dr. Jair Lício Ferreira dos Santos, que, por compartilhar o mesmo ambiente físico do meu orientador, muito contribuiu com suas opiniões e simpatia.

Aos funcionários do Departamento de Medicina Social da FMRP-USP Carolina Cecília Bruno Batista, Regina Helena Greggi, Mônica Elisabet Knack, Gilmar Mazzer, Sidney Porciúncula, Solange Pedersoli, Rosane Aparecida Monteiro, pela ajuda constante e por suportar nossas "urgências" e limitações. Aos demais funcionários deste departamento, a gratidão por contribuírem com sua simpatia para a redução do estresse típico desta etapa.

Às funcionárias do Núcleo de Vigilância Epidemiológica do Departamento de Medicina Social, pelo apoio e por me possibilitarem espaço físico para o exame dos pacientes. Em todos os momentos foram receptivas, simpáticas e solidárias.

Ao CD Márcio Conrado, chefe do setor odontológico da UBDS João Baptista Quartim, por pacientemente me permitir mudanças na escala de plantão que permitiram estar nos ambulatórios do HCFMRP-USP, em horários em que estaria impossibilitada. Aos colegas cirurgiões-dentistas que participaram dessas trocas.

Às Atendentes de Consultório Dentário da UBDS João Baptista Quartim, Lindy, Maria José, Geni, Maria Aparecida, Márcia e Carmem Célia, por tolerarem a 
minha visão de atenção odontológica que lhes gera árduo empenho profissional, e por colaborarem de modo vital para o meu desempenho profissional.

Expresso agradecimento especial a algumas pessoas cuja abnegada e extraordinária dedicação viabilizou a execução e término esta pesquisa:

Ao Prof. Dr. Laércio Joel Franco, orientador e aliado da pesquisa, que pacientemente tolerou minhas limitações, inclusive de disponibilidade de tempo, sempre contribuindo com sua sabedoria, simpatia e receptividade.

À Prof ${ }^{\mathrm{a}}$. Dr ${ }^{\mathrm{a}}$. Amábile Rodrigues Xavier Manço, pelo empenho em conseguir local para exame dos pacientes, e pelo estímulo e apoio constantes.

Ao Prof. Dr. Afonso Dinis Costa Passos, cujo insubstituível apoio e demasiado empenho, propiciou que os dados coletados fossem tabulados e analisados. Além de atuante, demonstrou boa vontade, dedicação e respeito ao trabalho e às pessoas. Ensinou-me a humildade, a alegria e a beleza de sermos sempre aprendizes. Foi amigo presente e fiel nas horas mais duras, permitindo-me reservar-lhe infindo respeito e carinho. É-me modelo de conduta.

Aos colegas do curso de pós-graduação, por me darem apoio e incentivo nos momentos de desânimo e desespero frente às dificuldades. Especial gratidão à Daniela Saez Sartorelli, Milta de Souza e Patrícia do Socorro Magalhães Franco do Espírio Santo, pelo carinhoso e fraternal apoio intelectual, operacional e emocional.

Aos pacientes dos ambulatórios de Cardiologia Isquêmica e de Hepatites, por participarem da pesquisa.

Às muitas pessoas que participaram da minha formação e engrandecimento acadêmico, pessoal, humanitário e cidadão.

Aos meus amigos, ouvintes e confidentes, sempre presentes em todas as "loucuras" que faço.

À minha mãe, Lucy, e meu pai, João Dário, pelo apoio em todos os momentos da vida.

Ao meu filho Guilherme, por talvez compreender que os inúmeros períodos de ausência me possibilitam "crescer" e que isto contribui para que conquistemos juntos grandiosos valores humanos.

A todos que ao longo da vida me facilitaram crescimento, seja através de criação de dificuldades estimulantes ao meu amadurecimento, seja com facilitações nos momentos de dificuldades.

Todos, sem exceção, deixaram marcas indeléveis em meu aprendizado científico e humano. 
Por fim, agradeço a Deus, por me permitir crer que nesta vida devemos respeitosamente produzir e "crescer" pensando em nós mesmos, na coletividade, no meio ambiente. Todos devemos doar nosso "quinhão", mesmo modesto. 


\section{AMIGOS}

Vinícius de Moraes

Tenho amigos que não sabe que são meus amigos. Não percebem o amor que lhes devoto e a absoluta necessidade que tenho deles.

A amizade é um sentimento mais nobre que o amor, eis que permite que o objeto dela se divida em outros afetos, enquanto o amor tem intrínseco o ciúme, que não admite a rivalidade.

E eu poderia suportar, embora não sem dor, que tivessem morrido todos os meus amores, mas enlouqueceria se morressem todos os meus amigos!

Até mesmo aqueles que não percebem o quanto são meus amigos e o quanto minha vida depende de suas existências ...

A alguns deles não procuro, basta-me saber que eles existem. Esta mera condição me encoraja a seguir em frente pela vida.

Mas, porque não os procuro com assiduidade, não posso lhes dizer o quanto gosto deles. Eles não iriam acreditar.

Muitos deles estão lendo esta crônica e não sabem que estão incluídos na sagrada relação de meus amigos.

Mas é delicioso que eu saiba e sinta que os adoro, embora não declare e não os procure.

E às vezes, quando os procuro, noto que ele não tem noção de como me são necessários, de como são indispensáveis ao meu equilíbrio vital, porque eles fazem parte do mundo que eu, tremulamente, construí e se tornaram alicerces do meu encanto pela vida.

Se um deles morrer, eu ficarei torto para um lado.

Se todos eles morrerem, eu desabo!

Por isso é que, sem que eles saibam, eu rezo pela vida deles.

E me envergonho, porque essa minha prece é, em síntese, dirigida ao meu bem estar. Ela é, talvez, fruto do meu egoísmo.

Por vezes, mergulho em pensamentos sobre alguns deles.

Quando viajo e fico diante de lugares maravilhosos, cai-me uma lágrima por não estarem junto de mim, compartilhando daquele prazer ... 
Se alguma coisa me consome e me envelhece é que a roda furiosa da vida não me permite ter sempre ao meu lado, morando comigo, andando comigo, falando comigo, vivendo comigo, todos os meus amigos, e, principalmente os que só desconfiam ou talvez nunca vão saber que são meus amigos!

A gente não faz amigos, reconhece-os. 


\section{SUMÁRIO}

RESUMO

\section{ABSTRACT}

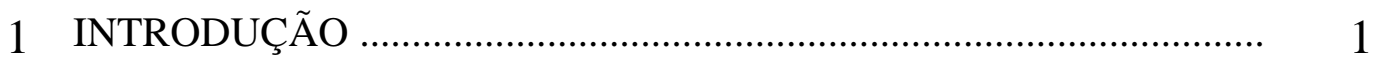

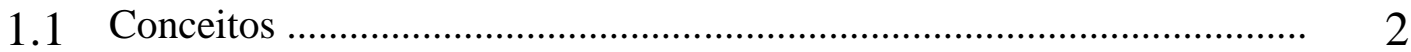

1.2 Evolução das pesquisas científicas em periodontia ............................... 7

1.3 Fatores de risco para as doenças periodontais ........................................ 15

1.4 Prevalência .................................................................................... 18

1.5 Classificação das doenças periodontais .................................................. 20

1.6 Doença periodontal como fator de risco para doenças sistêmicas ........... 23

2 OBJETIVOS ....................................................................... 26

3 CASUÍSTICA E MÉTODOS _........................................................... 27

3.1 População de estudo ........................................................................... 27

3.2 Critérios de inclusão e exclusão ............................................................. 29

3.3 Indicadores das condições de saúde bucal ............................................. 30

3.3.1 Índice Periodontal Comunitário (IPC) ............................................... 31

3.3.2 Perda de Inserção periodontal (PI) ................................................... 36

3.4 Coleta das informações ..................................................................... 38

3.5 Digitação e análise dos dados ........................................................... 42

4 RESULTADOS ........................................................................ 43

4.1 Recrutamento dos pacientes .......................................................... 43

4.2 Investigação periodontal ................................................................ 48

5 DISCUSSÃO _............................................................................ 83

5.1 Relevância ................................................................................. 83

5.2 Instrumento de medida das doenças periodontais ................................ 84

5.3 Dificuldades encontradas ............................................................. 86

5.4 Variáveis gerais ...................................................................... 88

5.5 Variáveis específicas ..................................................................... 93

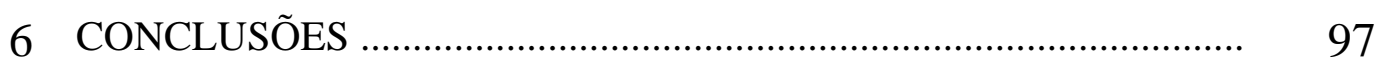

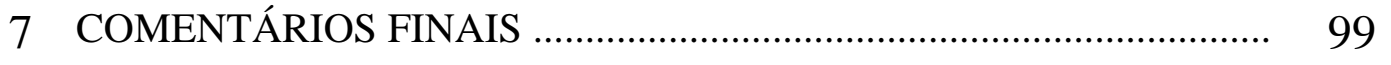

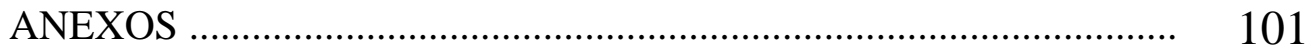

REFERÊNCIAS BIBLIOGRÁFICAS _............................................ 107 


\section{RESUMO}

BARILLI, A. L. A. Prevalência das Doenças Periodontais em Pacientes com Doença Isquêmica Coronariana Aterosclerótica, em Hospital Universitário, 2003. 117 p. Dissertação Mestrado - Faculdade de Medicina de Ribeirão Preto, Universidade de São Paulo, Ribeirão Preto-SP.

As doenças periodontais (DP) são precedidas em importância apenas pela cárie dentária como problema de saúde bucal coletiva no Brasil. Ambas são doenças infecciosas ainda muito prevalentes, entretanto é dada às DP uma importância questionavelmente secundária, pois não são sistematicamente investigadas e prevenidas em saúde pública. Pelo fato de sua prevalência ser atualmente desconhecida no Brasil, a alta freqüência das formas leves e moderadas das doenças periodontais na população como um todo e de suas formas mais graves em grupos ou indivíduos de risco, dentre estes os portadores de cardiopatias isquêmicas, motivou este estudo no Ambulatório de Cardiopatia Isquêmica do Hospital das Clínicas da Faculdade de Medicina de Ribeirão Preto da Universidade de São Paulo, cotejando os resultados com outros obtidos em grupo de pessoas não-cardiopatas atendidas na mesma instituição. Foi investigada a prevalência e gravidade das doenças periodontais, bem como a prevalência de seus fatores de risco, história médica da presença de doenças de interesse à periodontia (diabetes, hipertensão, acidente vascular cerebral) e comportamento relativo à higiene bucal. Dentre as 634 pessoas examinadas na fase de recrutamento dos participantes, 480 foram do grupo de pacientes cardiopatas isquêmicos e 154 de grupo de não-cardiopatas. Foram selecionados respectivamente de cada grupo, 58 e 62 participantes, na faixa etária de 30 a 79 anos, para a investigação periodontal. A média da idade foi de 53 anos em ambos os sexos para os pacientes cardiopatas e de 40 anos nos homens e 37 anos nas mulheres nos pacientes não-cardiopatas. Foram utilizados o Índice Periodontal Comunitário $(I P C)$ e o índice de Perda de Inserção periodontal (PI), ambos recomendados pela OMS (1999). Os resultados mostraram um predomínio de sextantes nos escores indicativos das formas graves da DP entre os pacientes cardiopatas $(74,1 \%$ contra $20,2 \%$; $<<0,00001)$. Dentre os pacientes cardiopatas 
apenas $1,1 \%$ dos sextantes exibiram saúde periodontal, contra 32,0\% nos pacientes não-cardiopatas $(\mathrm{p}<0,00001)$. No tocante a história pregressa da DP, mensuradas através da perda de inserção, 6,0\% dos sextantes não a exibiram entre os pacientes cardiopatas, contra 68,0\% dos não-cardiopatas ( $\mathrm{p}<0,00001)$. Eram portadores de fatores de retenção de biofilme dental 100,0\% dos pacientes cardiopatas e 82,3\% dos pacientes não-cardiopatas $(\mathrm{p}<0,001)$. Exigiam tratamento periodontal mais complexo, normalmente praticados por especialistas em periodontia, 94,8\% dos pacientes cardiopatas contra 33,9\% dos pacientes não-cardiopatas ( $\mathrm{p}<0,0001$ ). Necessitavam de tratamento de bolsas $\geq 6 \mathrm{~mm} 79,3 \%$ dos pacientes cardiopatas contra 9,7\% dos pacientes não-cardiopatas $(\mathrm{p}<0,0001)$. Alguns fatores de risco comprovado e/ou provável às DP, foram investigados nos pacientes cardiopatas e pacientes não-cardiopatas: observou-se tabagismo em 10,4\% e 33,9\% (p < 0,01), respectivamente; alcoolismo em 44,8\% e 24,2\% ( $\mathrm{p}<0,02$ ), respectivamente; diabetes em 29,3\% e 1,6\% ( $p<0,0001$ ), respectivamente; hipertensão arterial em $34,5 \%$ e $8,1 \%$ ( $<<0,001)$, respectivamente. Conclusões: As DP mostraram-se muito prevalentes nos dois grupos estudados, sendo de maior gravidade nos pacientes com cardiopatia isquêmica. A elevada prevalência de fatores de risco às DP aponta para a necessidade de adoção de estratégias de intervenção para minimizá-los.

Palavras-chave: doenças periodontais; cardiopatia isquêmica; Índice Periodontal Comunitário - IPC; perda de inserção periodontal. 


\begin{abstract}
Prevalence of periodontal diseases in patients with ischaemic coronary disease in an University Hospital, 2003.

Periodontal diseases are preceded in importance only by dental caries as oral public health problem in Brazil. Both are infectious diseases and with high prevalences, however, a secondary importance is given to periodontal diseases because they are not routinely investigated and prevented at public health level. Presently its prevalence is not known in the Brazilian population. The high prevalence of mild and moderate forms of periodontal diseases in the general population, and its severe forms in specific groups or in high risk patients, as those with ischaemic coronary diseases, motivated this survey. It was carried out among patients from the Outpatient Clinic of Ischaemic Coronary Disease - Hospital das Clínicas da Faculdade de Medicina de Ribeirão Preto da Universidade de São Paulo - and using for comparisons patients from other clinics of the same hospital. The prevalence and severity of periodontal diseases were investigated, as well as the prevalence of their risk factors, medical history of diseases with periodontic interest (diabetes, hypertension, stroke), and behaviour related to oral hygiene. During the recruitment phase, among 634 patients examined, 480 were from the group with cardiopathy and 154 from the group without cardiopathy. From each group were selected, respectively, 58 and 62 participants, aged 30 to 79 years for the periodontal investigation. Mean age was 53 years for both sexes in the group with cardiopathy and 40 years for men and 37 years for women in the group without cardiopathy. The Community Periodontal Index and the Attachment Periodontal Index, both recommended by the World Health Organization (1999), were used. Results showed a predominance of sextants in the scores indicating severe forms of periodontal diseases among patients with cardiopathy (74.1 vs. 20.2\%; $\mathrm{p}<0.00001$ ). Among patients with cardiopathy, only $1.1 \%$ of the sextants showed periodontal health against $32.0 \%$ in the other group ( $\mathrm{p}<0.00001)$. Previous history of periodontal diseases, measured through lost of insertion, was present in $6.0 \%$ of the sextants in patients with cardiopathy and $68.0 \%$ in those without cardiopathy $(\mathrm{p}<0.0001)$. All
\end{abstract}


patients with cardiopathy and $82.3 \%$ of those without cardiopathy were carriers of retention factors of dental biofilm $(\mathrm{p}<0.001)$. It was found that $94.8 \%$ of the patients with cardiopathy against $33.9 \%$ of the other group $(\mathrm{p}<0.0001)$ required more complex periodontal treatment, usually performed by periodontal specialists. Treatment of sites $=6 \mathrm{mmm}$ was required by $79.3 \%$ of the patients with cardiopathy and by $9.7 \%$ from the other group ( $\mathrm{p}<0.0001)$. The frequency of confirmed or possible risk factors for periodontal diseases in the groups with and without cardiopathy were, respectively: smoking - 10.4 and 33.9\% ( $\mathrm{p}<0.001)$; alcoholism 44.8 and $24.2 \%(\mathrm{p}<0.02)$; diabetes -29.3 and $1.6 \%(\mathrm{p}<0.0001)$; hypertension -34.5 and $8.1 \%$ ( $\mathrm{p}<0.001)$. Conclusions: Periodontal diseases were highly prevalent in the two groups studied, but with higher severity among patients with cardiopathy. The high frequency of risk factors for periodontal diseases in both groups appointed to the need of intervention strategies towards these risk factors.

Key-words: periodontal diseases; ischaemic coronary diseases; Community Periodontal Index - CPI; periodontal attachment loss. 


\section{INTRODUÇÃO}

No Brasil, a investigação periodontal não é sistematicamente praticada em escala nacional, não havendo dados atuais passíveis de extrapolação para diferentes faixas etárias. Inquéritos têm sido realizados no sentido de se conhecer sua prevalência em crianças, adolescentes e alguns grupos de risco. Este interesse em se detectar a prevalência de doenças odontológicas é diferente quando se considera como objeto de estudo a cárie dentária, ampla e sistematicamente pesquisada no país, inclusive com dados para todas as regiões brasileiras. É fato claro aos olhos de todos que, como doença bucal de interesse em saúde coletiva, ainda reina "solitária" a cárie dentária, restando às demais condições bucais (doenças periodontais, oclusopatias, câncer bucal, fenda labiopalatais, fluorose dentária) uma importância secundária. Óbvio que se deve respeitar o critério de freqüência com que ocorrem as doenças bucais, para serem classificados importantes pela saúde pública. Porém, para que se conheça esta freqüência, estudos descritivos ainda são necessários e deveriam, respeitada a metodologia para o máximo controle dos vieses, ser implementados em caráter permanente e periódico, para amostras de todos os segmentos da população brasileira. Com base no exposto, optou-se por conhecer a prevalência das doenças periodontais em amostra de pacientes do Hospital das Clínicas da Faculdade de Medicina de Ribeirão Preto da Universidade de São Paulo (HCFMRP-USP). 


\subsection{CONCEITOS}

Como doença periodontal, termo não específico que se refere a qualquer processo de doença que afeta o periodonto, deve-se entender a doença periodontal inflamatória, que compreende as diversas formas de gengivite e periodontite (Armitage, $1996^{7}$; Ramfjord \& Ash, $1991^{85}$ ).

Essas formas de doença são infecciosas, crônicas e freqüentemente assintomáticas, ocorrendo como resultado da exposição do periodonto à ação das bactérias aderidas à superfície dentária, de natureza não descamativa (Axelsson \& Lindhe, $1981^{9}$ ).

A placa bacteriana se caracteriza como uma massa bacteriana mole e aderente, que se deposita sobre as superfícies dentárias continuamente. Não é removida com bochechos, jatos de ar ou mastigação de alimentos duros ou fibrosos. Mais recentemente estabeleceu-se que as placas formam verdadeiros biofilmes, que são comunidades bacterianas complexas, com numerosos microambientes com $\mathrm{pH}$, tensão de oxigênio e composição diferentes, aderindo em qualquer superfície sólida da cavidade bucal (esmalte, cemento radicular, dentina, restaurações, implantes etc.) e de difícil remoção. Ausência total da placa bacteriana não é possível, no entanto é possível manter gengiva e demais estruturas periodontais sadias se a quantidade da placa é pequena, se a microbiota é pouco virulenta e se os mecanismos de defesa orgânica são eficazes (Page \& Kornman, $1997^{77}$ ).

Costerton et al. $\left(1994{ }^{28}\right.$ e $\left.1999^{29}\right)$ consideram que o biofilme dental é uma “matriz contendo populações microbianas aderidas entre si ou em outras superfícies". A estrutura organizada propiciaria a interação quase simbiótica entre os diversos microorganismos, permitindo que bactérias anaeróbias fiquem "protegidas" no interior de microcolônias com formações em "cogumelo". A matriz extracelular de polissacarídeos que envolve o biofilme permite circulação dos nutrientes e metabólitos. Esta estrutura tem características tão sofisticadas que pode ser comparada a uma verdadeira "sociedade bacteriana".

O reconhecimento da especificidade do biofilme dental subgengival e da existência de diversas formas de doenças periodontais associadas a diferentes 
patógenos, levou a um melhor entendimento do processo da doença. Offenbacher $\left(1996^{73}\right)$ considera que "a doença periodontal é uma mistura específica de bactérias que causam destruição periodontal em um indivíduo susceptível”.

Segundo Moore \& Moore $\left(1994{ }^{69}\right.$ ), de acordo com a teoria da "placa específica", bactérias específicas (periodontopatógenos) com seus peculiares fatores de virulência provocarão um aumento da agressão que dificulta ainda mais o processo de defesa pelo organismo. Quando este não consegue suplantar a agressão, ocorre migração apical do epitélio juncional e perda de inserção conjuntiva. $O$ processo saúde-doença periodontal é dinâmico e dependente da virulência dos bactérias e da capacidade de defesa do organismo. O padrão de progressão está diretamente relacionado ao binômio agressão e defesa.

Essas bactérias formam o biofilme dental, que contem mais de 400 espécies microbianas apresentadas como uma complexa massa bacteriana na margem gengival e no interior do sulco gengival ou da bolsa periodontal, com cerca de $2 \mathrm{x}$ $10^{11}$ bactérias/grama, inclusive com as espécies Gram-negativas anaeróbias típicas das doenças periodontais. As bactérias formadoras deste biofilme são habitantes normais da cavidade bucal, que se acumulam sobre uma película que recobre a superfície dos dentes mesmo que os procedimentos de limpeza sejam convenientemente realizados. A colonização bacteriana se dá normalmente e em poucas horas. Não havendo interferência no processo, o biofilme dental se modificará quantitativa e qualitativamente, quando fica mais propício ao aparecimento da doença periodontal inflamatória (Christersson et al., $1989^{26}$; Listgarten, $1987^{53}$; Socransky, $1977^{95}$; Theilade, $1996^{99}$ ).

As doenças periodontais são o resultado da destruição dos tecidos periodontais pela ação dos produtos tóxicos liberados na área subgengival pelos periodontopatógenos específicos, como também pela resposta inflamatória desencadeada pela presença de microorganismos e seus sub-produtos tóxicos. A inflamação leva à produção local de citocinas e mediadores biológicos (interleucinas e prostaglandinas). Estão, portanto, associadas com a colonização da área subgengival por bactérias patogênicas específicas, algumas destas com capacidade de invadir os tecidos periodontais provocando danos. As bolsas profundas, observadas 
nas formas graves de doença periodontal, oferecerão um microambiente mais propício ao crescimento microbiano anaeróbio (Allenspach-Perzilka \& Guggenheim, $1983^{6}$; Asikainen, $1986^{8}$; Christersson et al., $1989^{26}$ ).

O início e a progressão da infecção periodontal são modificados por condições ou fatores locais e sistêmicos, denominados fatores de risco. Portanto, as diferentes formas de doença periodontal são associadas à presença e ação dos microorganismos do biofilme dental, muito embora as bactérias envolvidas sejam diferentes, e a resposta seja modificada por fatores de risco. Esses conceitos são fundamentais para aplicação de medidas preventivas e terapêuticas, para se reconhecer, identificar e eliminar ou controlar o fator etiológico primário (biofilme dental) como também os fatores de risco associados ao processo de doença (Bretz, $1996^{20}$; Genco, $1996^{40}$; Gjermo, $1991^{41}$; Ramfjord \& Ash, $1991^{86}$; Ramfjord et al., $1982^{87}$; Sakki et al., $1998{ }^{91}$; Van Dyke, $1993^{101}$, Westfelt et al., $1998{ }^{102}$ ).

Bretz (1996) ${ }^{20}$, Loesche et al. (1997) ${ }^{60}$ e Robinson et al. (1998) ${ }^{89}$ afirmam que para se compreender as doenças periodontais é fundamental reconhecê-las como doenças infecciosas causadas por bactérias anaeróbias e com fortes evidências de transmissibilidade. Importante entender também a relação entre agente agressor e defesas do hospedeiro, levando à saúde ou à doença. Portanto, é o desequilíbrio entre o agente agressor e as defesas do hospedeiro que favorece a instalação da doença. Entre os microorganismos da microbiota bucal temos os ligados à saúde, outros ligados à cárie dentária e outros ainda relacionados às doenças periodontais. A teoria da placa específica domina o conceito de potencial desenvolvimento da doença periodontal. Nesta teoria apenas um número finito de bactérias tem potencial de levar à doença, ou seja, das centenas de espécies microbianas, poucas espécies levam às doenças periodontais. O grupo dessas doenças tem como características o caráter multifatorial, as populações e sítios de risco. Portanto, além dos agentes bacterianos, o ambiente social aumenta a suscetibilidade à doença periodontal destrutiva. Compondo este ambiente social temos a família, políticas de saúde, atitudes, educação, emprego e nível sócio-econômico-cultural. O fator de risco apresenta-se como um aspecto característico do comportamento ou exposição ao meio ambiente que está associado com uma doença destrutiva dos tecidos periodontais. Alguns 
desses fatores podem ser modificados ou não (microbiota periodontal, diabetes, tabagismo, alterações de neutrófilos, HIV, estresse etc.).

A causa primária da doença periodontal é a infecção por periodontopatógenos presentes em um hospedeiro susceptível. Segundo Slots $(1986)^{94}$, das centenas de espécies de microorganismos isolados da microbiota subgengival, apenas cerca de vinte a trinta são consideradas periodontopatogênicas.

Os principais microorganismos associados à doença periodontal são Porphyromonas gingivalis, Actinobacillus actinomycetemcomitans, Bacteroides forsythus, espiroquetas, Prevotella intermedia, Campylobacter rectus, Eubacterium nodatum, Treponema denticola, Streptococcus intermedia, Prevotella nigrescens, Peptostreptococcus micros, Fusobacterium nucleatum e Eikenella corrodens (Christersson et al., $1989^{26}$; Grossi et al., $1994{ }^{42}$; Slots, $1986{ }^{94}$ ). Essas espécies bacterianas envolvidas nas formas mais graves das doenças periodontais, são anaeróbios não detectados através de exames exeqüíveis em abrangentes estudos epidemiológicos de campo, até o momento.

Os estudos de associações entre patógenos periodontais e doença periodontal progressiva indicam que a associação é muito $\underline{\text { forte }}$ para Actinobacillus actinomycetemcomitans, espiroquetas, Porphyromonas gingivalis, é forte para Bacteroides forsythus, Prevotella intermedia, Treponema denticola, Eubacterium nodatum, é moderada para Streptococcus intermedia, Prevotella nigrescens, Peptostreptococcus micros, Fusobacterium nucleatum, Campylobacter rectus, Eikenella corrodens, em estágios iniciais para Selenomonas species, Gram-negative enterici rods, Pseudomonas species, Straphylococcus species (Asikainem, $1986^{8}$; Christersson et al., $1989^{26}$; Grossi et al., $1994^{42}$; Slots, $1986^{94}$ ).

Além do caráter infeccioso da doença periodontal, alguns fatores podem modificar o risco e a sua dinâmica. Esses são denominados fatores ambientais e incluem o tabagismo e o estresse emocional. O cigarro afeta o sistema vascular e as respostas humoral, celular e inflamatória. O estresse parece reduzir a função imune e aumentar corticosteróides e citocinas circulantes, além de alterar hábitos de higiene 
oral, o que afeta mais ainda a condição periodontal (Genco, $1996{ }^{40}$; Grossi et al., $1994^{42}$; Sakki et al., $1998^{91}$ ). 


\subsection{EVOLUÇÃO DAS PESQUISAS CIENTÍfICAS EM PERIODONTIA}

Nas últimas décadas, em todo o mundo, a odontologia e a periodontia, assim como as ciências da saúde em geral, passaram por modificações conceituais, decorrentes de mudanças nos paradigmas norteadores dessas ciências, bem como decorrentes dos imensos avanços nas técnicas, nos métodos e nos equipamentos, ocorridos no século XX.

Um marco da literatura científica em periodontia, divisor de conceitos e técnicas, foi o clássico artigo de Löe et al. (1965) ${ }^{58}$, que comprovou a relação entre o biofilme dental e o estabelecimento da fase inicial da doença periodontal (gengivite). Desde este estudo denominado Gengivite Experimental em Humanos ficou comprovado que, após um período de tempo de acúmulo do biofilme dental, todos os indivíduos desenvolverão inflamação da gengiva marginal - gengivite. A variação no quadro inflamatório é decorrente de diferentes respostas do organismo, que leva a maior ou menor tempo para que os sinais clínicos surjam. As características do processo inflamatório gengival pode dar boas condições para o aparecimento do biofilme subgengival.
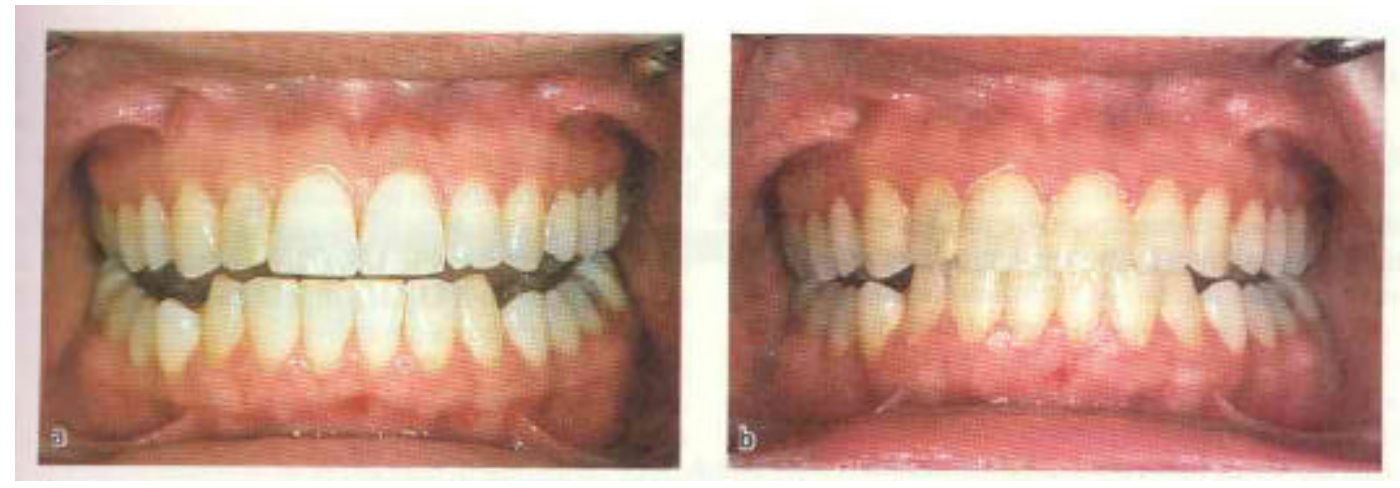

Figura 1 - Modelo de Gengivite Experimental em Humanos (Löe et al., $1965{ }^{58}$ ): no início do experimento de acúmulo de biofilme dental, o voluntário está com os dentes limpos e gengiva clinicamente saudável. Após 21 dias de suspensão das medidas de higiene bucal, o voluntário exibe depósitos bacterianos na superfície dentária (biofilme) e, conseqüente desenvolvimento de inflamação 
da gengiva marginal. Após a instauração dos procedimentos de higiene, a saúde gengival é recuperada em poucos dias.

(Foto extraída do livro Tratado de Periodontia Clínica e Implantologia Oral, de Jan Lindhe, cap. 3, p. 67, Placa e Cálculo Dentais, de N. P. Lang, A Mombelli, R. Attström. Rio de Janeiro: Guanabara Koogan, 1997)

No entanto, as mais profundas mudanças de paradigmas em periodontia podem ser atribuídas aos estudos epidemiológicos de Löe et al. (1986) ${ }^{56}$, que avaliaram a história natural das doenças periodontais em indivíduos sem qualquer acesso a tratamento e, portanto, sem interferência externa de profissionais. Após 20 anos de observação verificaram que $81 \%$ dos pacientes apresentavam periodontite de evolução lenta, $8 \%$ de progressão rápida e $11 \%$ não apresentaram perda de inserção apesar de terem gengivite. Os resultados obtidos por eles, adicionados a resultados de outros autores, romperam com o raciocínio linear da etiologia e progressão das doenças periodontais, além de iniciar um período de emprego de métodos complexos e sofisticados na pesquisa científica em periodontia. Nesta, a compreensão dos fenômenos imunológicos, genéticos, microbiológicos, bioquímicos e patológicos permitiram grande avanço na percepção integral do indivíduo, sugerindo que as doenças que afetam o periodonto podem ter influência sobre a saúde geral ao afetar ou contribuir para o desenvolvimento de patologias em outros órgãos e sistemas do corpo humano.

É amplamente reconhecido na literatura científica que como fator modificador do processo saúde-doença tem-se o desequilíbrio entre a virulência do biofilme dental e a resposta do organismo. Portanto, a microbiota associada à condição sistêmica têm sido as maiores responsáveis pelo tipo e padrão de progressão das doenças periodontais. Entretanto, outros fatores podem colaborar neste processo por estarem influenciando a resposta ou defesa do organismo (Beck, $1996^{17}$; Bretz, $1996^{20}$; Clark et al., $1995^{27}$; Gjermo, $1991^{41}$; Harber, $1993^{43}$; Mealey, $1996{ }^{66}$; Robinson et al, $1998{ }^{89}$; Sakki et al, $1998{ }^{91}$; Van Dyke, $1993{ }^{101}$ ). Dentre esses, têm-se algumas condições sistêmicas que influenciam na progressão e gravidade das doenças periodontais, dentre elas temos a diabetes (que interfere na 
capacidade de reparação), a condição de portador do HIV (por diminuir os elementos de defesa), neutropenia cíclica, leucemias, síndrome de Down, síndrome de PapillonLefrève, síndrome de Chediak-Higashi, alterações hormonais encontradas na gravidez, climatério e nas usuárias de contraceptivos (alteram a microbiota subgengival), uso de medicamentos que exacerbam a resposta ao biofilme levando à produção de colágeno e formação de hiperplasia gengival (fenitoína, nifedipina, ciclosporina), o estresse emocional (por diminuir a capacidade de defesa do organismo), tabagismo (por reduzir a microcirculação gengival além de causar danos à células de defesa, em especial os neutrófilos).

Williams \& Offenbacher (2000) ${ }^{103}$ consideram que um ramo emergente da periodontia, definida como Periodontia Médica, tem inúmeros trabalhos científicos apontando para a forte associação entre saúde periodontal e saúde ou doença sistêmica, portanto, na relação bidirecional segundo a qual as doenças periodontais podem influenciar negativamente a saúde geral das pessoas, tanto quanto diversas patologias gerais podem afetar o início e a progressão das doenças periodontais, ou mesmo fazer parte do quadro de manifestações de uma doença sistêmica.

Sob os conceitos deste novo paradigma científico, disponíveis na literatura, verifica-se a influência das doenças periodontais nas alterações cardiovasculares, na gravidez e parto, e nas doenças pulmonares (Mealey, $1996{ }^{66}$; Mendez, $1998{ }^{68}$; Offenbacher, $1996^{73}$; Page, $1998^{76}$ ).

Estudos epidemiológicos experimentais, assim como evidências clínicas, têm sugerido que o desenvolvimento da doença cardiovascular (DCV), aterosclerose e infarto cerebral podem ser influenciados por infecção (Matilla et al., $1995{ }^{64}$ ). Neste contexto, tem-se demonstrado que pessoas com manifestações clínicas de DCV ou infarto cerebral apresentam infecções periodontais mais graves (Matilla et al., 1989 63; Matilla et al., $1995^{64}$ ) e que a gravidade da doença periodontal apresentou correlação positiva com a aterosclerose (Matilla et al., $1993{ }^{65}$ ).

Portadores de doença periodontal grave apresentam, segundo DeStefano et al. $(1993)^{34}$, um risco de apresentarem morbi-mortalidade $25 \%$ maior para doenças cardiovasculares se comparados com portadores de doença leve, mesmo em presença 
de outros fatores. Observaram que pessoas com idade inferior a 50 anos e doença periodontal grave possuem $70 \%$ de risco em desenvolver doença cardiovascular no futuro.

Segundo Coutinho et al. (2000) ${ }^{30}$, apesar dos fatores de risco mais comuns associados às doenças cardiovasculares terem sido identificados pela medicina, cerca de um terço dos portadores de aterosclerose não têm nenhum deles, o que estimula a identificação de outros fatores de risco. Utilizando técnicas de biologia molecular, encontraram Chlamydia pneumoniae em $12 \%$ dos pacientes portadores de aterosclerose submetidos a procedimentos cirúrgicos. No entanto ressaltam que este achado é controverso por não existirem ainda evidências de causalidade, podendo a bactéria ser um colonizador inócuo.

As doenças cardiovasculares, incluindo a aterosclerose, a isquemia e o infarto do miocárdio, ocorrem como resultado de uma complexa interação de diversos fatores genéticos e ambientais, agudos e crônicos. Os fatores de risco incluem, por exemplo, idade, metabolismo lipídico, obesidade, hipertensão arterial, diabetes, níveis de leucócitos e fibrinogênio, agregação plaquetária, nível socioeconômico, atividade física, estresse, dieta, tabagismo e infecções crônicas.

Ross (1999) ${ }^{90}$ considerou que a aterosclerose, doença crônica que leva à obliteração progressiva dos vasos sangüíneos, tem como fator desencadeante uma injúria inicial capaz de provocar uma resposta inflamatória com participação de macrófagos, linfócitos, células endoteliais e da musculatura lisa dos vasos. Esta injúria inicial pode ser resultante de agentes como: aumento da quantidade de colesterol circulante, atrito do sangue na parede dos vasos, monóxido de carbono dos cigarros e, mais recentemente considerado, os agentes infecciosos.

Como exemplos de microorganismos capazes de se disseminar pelo sangue e produzir aterosclerose, temos Chlamydia pneumoniae, Helicobacter pylori, cytomegalovirus, vírus tipo 2 do Herpes simples e patógenos periodontais Gramnegativos anaeróbios (Allenspach-Perzilka et al., $1983^{6}$; Listgarten, $1987^{53}$; Moore \& Moore, $1994^{69}$; Ross, $1999^{90}$; Socransky, $1977^{95}$ ). 
Nas periodontites, alguns microorganismos do biofilme dental (Actinobacillus actinomycetemcomitans, Streptococcus sanguis e Porphyromonas gingivalis) que possuem capacidade de agregar plaquetas e se disseminar através da corrente sangüínea, podem contribuir para a formação de trombos, para a ocorrência da aterosclerose, para o aumento do risco de isquemia, para eventos tromboembólicos agudos e infarto do miocárdio (Herzberg \& Meyer, $1998^{46}$ ).

Estudos recentes consideram que a natureza infecciosa das doenças periodontais poderia produzir a injúria inicial desencadeadora da aterosclerose, ou mesmo provocar o agravamento de processo aterosclerótico pré-existente. Essas evidências foram sugeridas em estudos de coorte retrospectivo, transversais e casocontrole realizados por Mattila et al. $\left(1989^{63}, 1993^{65}, 1995^{64}\right)$, DeStefano et al. $(1993)^{34}$, Paunio et al. (1993) ${ }^{81}$, Beck et al. (1996) ${ }^{16}$, Joshipura et al. (1996) ${ }^{48}$, Genco et al. (1997) ${ }^{39}$, Mendez et al. (1998) ${ }^{68}$, Morrison et al. (1999) ${ }^{70}$ e Wu et al. (2000) ${ }^{104}$. Nesses estudos verificaram que a associação entre as condições bucais e aterosclerose é consistente em diferentes amostras de populações, e também demonstraram que as condições bucais precedem os eventos coronarianos.

A habilidade de certos periodontopatógenos de livrar-se dos mecanismos de defesa local do hospedeiro e de se apresentar como um desafio sistêmico, tem sido reconhecida. Ocorre um aumento considerável nos níveis de anticorpos humorais sistêmicos como resposta à infecção por esses patógenos, assim como pelas suas endotoxinas. O Actinobacillus actinomycetemcomitans (Aa) produz uma leucotoxina com capacidade de lise de neutrófilos e monócitos, o que impede sua função fagocitária (Asikainen, $1986^{8}$ ). Sua capacidade de invadir tecidos também pode provocar formação de antígeno específico anti-Aa em níveis séricos elevados (similares aos presentes em infecções sistêmicas disseminadas, como na sífilis terciária). Já o Porphyromonas gingivalis possui enzimas que degradam imunoglobulinas, componentes do complemento e da matriz extracelular.

Além da capacidade de invasão tecidual de certos periodontopatógenos, a perda da integridade dos epitélios sulcular e juncional favorece o deslocamento bacteriano para o tecido conjuntivo adjacente, com o conseqüente aumento da concentração de anticorpos específicos para esses microorganismos (IgM, IgG e IgA) 
representando um desafio sistêmico constante, ou a ocorrência de bacteriemias transitórias. Quanto mais grave a infecção periodontal, maior quantidade de microorganismos são encontrados na corrente sangüínea, mesmo em procedimentos aparentemente inócuos, como a higiene bucal.

Beck et al. (1996) ${ }^{16}$ observaram durante período de 18 anos que os níveis de perda óssea estão associados à alta incidência de doenças cardiovasculares fatais ou não, assim como a história de derrame.

Apesar das duas mais comuns doenças bucais (cárie dentária e doenças periodontais) serem de natureza infecciosa, nesta última a possibilidade de bacteriemias é maior pela proximidade dos agentes infecciosos com o tecido conjuntivo e seus componentes vasculares. Page (1998) ${ }^{76}$ afirmou que uma amostra de biofilme dental, removida com um movimento de raspagem subgengival utilizando cureta, possui $10^{7}$ a $10^{8}$ das espécies microbianas presentes na cavidade bucal, incluindo anaeróbios Gram-negativos, que estão em íntimo contato com uma área aproximada de $72 \mathrm{~cm}^{2}$ em pacientes portadores de doença periodontal moderada a grave, com presença de bolsas de 5 e $6 \mathrm{~mm}$. Como os patógenos periodontais são anaeróbios, mesmo que a oxi-redução entre os ambientes da bolsa periodontal (anaeróbio) e da corrente sangüínea (aeróbio) os torne inviáveis, a endotoxina (LPS lipopolissacárides) da parede microbiana pode estimular a agregação plaquetária, contribuindo para a formação de trombos e placas ateromatosas. O posterior acúmulo de lipídios é uma característica deste processo e, numa fase mais avançada, a placa de ateroma pode ser recoberta por uma cápsula fibrosa que pode desprender-se formando trombos e produzindo a oclusão da artéria que precede o infarto.

As bacteriemias transitórias podem ocorrer em procedimentos odontológicos invasivos e não-invasivos e também ocorrem em ações do cotidiano como mastigação e escovação dentária (Herzberg \& Meyer, $1998{ }^{46}$ ). Não representam ameaça quando são de baixa intensidade e duração, porém na presença de infecções periodontais graves, um grande número de microorganismos poderia invadir a corrente sangüínea e produzir os fenômenos de risco à aterosclerose e eventos cardiovasculares. Assim, as bactérias periodontopatogênicas poderiam contribuir 
direta ou indiretamente para o desenvolvimento de trombos e possivelmente de alterações cardiovasculares.

As doenças cardiovasculares e periodontais, ambas crônicas e multifatorais, têm em comum uma base genética de susceptibilidade, e também componentes comportamentais importantes, como os hábitos relacionados à dieta, à higiene e à prática de tabagismo, dentre outras. Alguns são relevantes na etiopatogenia da cárie e da doença periodontal tanto quanto das doenças cardiovasculares, além de indicar pessoas com hábitos não compatíveis com saúde e com outros fatores de risco para as doenças cardiovasculares. Portanto, apresentam uma série de características em comum: ambas ocorrem com maior freqüência em pessoas mais velhas, do sexo masculino, com baixo nível sócio-econômico-cultural, fumantes, diabéticos, com quadros de estresse e com importante predisposição genética (Frare et al., $199{ }^{38}$; Listgarten, $1987^{53}$; Marcaccini et al., $1997^{61}$; Markkanen et al., $1980{ }^{62}$; Sakki et al., $\left.1998^{91}\right)$.

O tabagismo é atualmente considerado como um potente fator modificador na progressão e gravidade das doenças periodontais. Produz uma vasoconstrição vascular periférica produzida pela ação farmacológica dos constituintes do cigarro, além de provocar redução da defesa gengival devido a alterações funcionais dos leucócitos polimorfonucleares presentes no sulco gengival, que passam a apresentar pouca atividade fagocitária, baixa viabilidade e redução na quimiotaxia. Em fumantes as camadas mais profundas dos tecidos periodontais apresentam quadros de doença periodontal ativa, sem exibir sinais clínicos de sangramento e rubor gengival. A ação deletéria do fumo se estende também ao processo de cura após terapia periodontal básica, assim como na manutenção da saúde periodontal (RiveraHidalgo, $1986^{88}$; Stoltenberg, $1993^{97}$; Zambom, $1996{ }^{105}$ ).

A associação entre as doenças periodontal e cardiovascular envolve uma série de mecanismos como o efeito direto do agente infeccioso na formação do ateroma, o efeito indireto ou mediado pelo hospedeiro desencadeado pela infecção, predisposição genética tanto para uma doença como para outra, além de uma série de características em comum, como ocorrer com maior frequiência em pessoas mais velhas, do sexo masculino, com menor nível sócio-econômico-cultural, tabagistas, 
diabéticos e estressados (Ballieux, $1991^{15}$; Beck, $1996{ }^{17}$; Clark \& Hirsch, $1995^{27}$; Rivera-Hidalgo, $1986^{88}$; Stoltenberg, $1993{ }^{97}$; Zambom, $1996{ }^{105}$ ). 


\subsection{FATORES DE RISCO PARA AS DOENÇAS PERIODONTAIS}

Os fatores de risco estão relacionados à conduta, agentes ou condições que podem estar associados com o aumento da prevalência, extensão e gravidade das doenças periodontais. Incluem pobre higiene bucal, doenças sistêmicas, irritantes locais, patógenos bucais e valores culturais. Alguns fatores associados às doenças periodontais, porém não etiologicamente envolvidos, como idade, raça, gênero e nível socioeconômico, são denominados indicadores de risco. Alguns desses fatores são considerados neste subtítulo.

O fumo ou tabagismo tem ação na prevalência e na gravidade da doença periodontal, na resposta à terapia e na progressão da doença, além da ação própria dos sub-produtos do tabaco. Em um estudo com 1.426 indivíduos, Grossi et al. (1994) ${ }^{42}$ concluíram que o hábito de fumar apresentou uma alta correlação com perda de inserção, sendo dose-dependente com a quantidade fumada e tempo de duração do vício. Fumantes ocasionais apresentavam perda óssea maior que não fumantes; $56 \%$ de não-fumantes apresentavam-se com saúde e 7,5\% com doença periodontal grave; apenas 9,2\% dos fumantes pesados apresentavam-se com saúde. Consideraram que nicotina e cotinina podem ser encontradas na saliva, no plasma, na urina, no fluido gengival e nas superfícies radiculares de dentes com doença periodontal em fumantes; o fumo reduz a velocidade de mobilidade dos neutrófilos; a área anterior é mais comprometida que a posterior; reduz resposta inflamatória etc. $\mathrm{Na}$ gengivite necrosante aguda (GNA) o fumo potencializa os efeitos do estresse mental, reduzindo o volume sangüíneo na gengiva e produzindo necrose tecidual. Parece exercer um importante papel no desenvolvimento da periodontite refratária (Haber, $1993{ }^{43}$; Haber \& Kent, $1992{ }^{44}$; Kinane \& Radvar, $1997^{49}$; Rivera-Hidalgo, $1986^{88}$; Stoltenberg, $1993{ }^{97}$; Zambom, $1996{ }^{105}$ ).

O estresse está também entre os fatores de risco por provocar alteração no equilíbrio existente entre destruição e reparo teciduais, resultando em dano. O estresse crônico leva à diminuição da resposta imune e o estresse ocupacional está relacionado às mudanças na saúde periodontal, alterando a profundidade de 
bolsa no período de um ano. A GNA igualmente associa-se ao estresse (Axtelius et al., $1998^{11}$; Ballieux et al., $1991^{15}$ ).

A idade por si só não é um fator bem definido de risco à doença periodontal, mas sabe-se que os quadros graves normalmente são mais observados em pessoas com mais idade, talvez pelo efeito cumulativo da destruição periodontal (Beck, 1996 ${ }^{17}$; Frare et al., $1997^{38}$; Marcaccini et al., $1997^{61}$ ).

Quanto ao gênero, há controvérsias entre os autores (Sakki et al., $1998^{91}$ ). No entanto, pacientes do sexo masculino exibem quadros mais graves, isto sendo explicado talvez por um provável protetor hormonal no gênero feminino e pelo fato dessas pessoas normalmente terem o hábito de cuidar de sua saúde com mais regularidade que as do sexo masculino.

O nível socioeconômico é um fator de confusão. No entanto, quadros graves são freqüentemente observados em pessoas com baixo nível socioeconômico (Markkanen et al., $1980{ }^{62}$ ), o que talvez se explique também pela menor procura por serviços de saúde. Quando se elimina as variáveis relacionadas ao tabagismo e higiene bucal, a associação entre baixo nível socioeconômico e doença periodontal grave desaparece (Grossi et al., $1994^{42}$ ).

Em relação aos fatores genéticos, ocorrem questionamentos se há suscetibilidade genética aos patógenos periodontais ou se é resultado de respostas imunes alteradas às bactérias normalmente presentes. Sabe-se que a infecção por microorganismos é sempre importante para desencadear a doença periodontal. $\mathrm{Na}$ Periodontite de Estabelecimento Precoce (PEP) ou progressiva rápida, há um gene de susceptibilidade à esta doença, fazendo com que ocorra uma predisposição genética, com $8 \%$ da população podendo apresentar esta forma de doença ${ }^{56}$. Na Periodontite Juvenil (PJ) há fatores ambientais modificados (fumo e outras associações bacterianas) associados a fatores genéticos também modificados (resposta $\operatorname{IgG}$ etc.), que levam às formas localizada ou generalizada da doença periodontal (Chapple, $1997^{24}$; Ramfjord \& Ash, $1991^{86}$ ). 
Para verificar-se o estabelecimento da doença periodontal temos os indicadores ou os marcadores de risco, que são fatores preditivos, isto é, associados com um aumento da probabilidade de desenvolver doença periodontal no futuro. Esses indicadores clínicos são importantes e soberanos na definição e manejo das doenças periodontais. Os principais são sangramento à sondagem, sangramento à sondagem associado com supuração (detecta a destruição dos tecidos periodontais naquele momento), perda de inserção progressiva (recessão gengival associada à profundidade de sondagem), mobilidade progressiva, presença de cálculo subgengival (pesquisa de áreas de rugosidade radicular), envolvimento de furca e envolvimento muco-gengival (considera a largura da mucosa ceratinizada ou gengiva inserida). Estabelecido o diagnóstico inicial ou presuntivo de uma das formas de doença periodontal, as radiografias são muito importantes para se poder estabelecer a confirmação diagnóstica e os passos de tratamento (Armitage, $1996{ }^{7}$; Chapple, 1997 ${ }^{24}$; Pinto, $2000{ }^{84}$; Ramfjord, $1991{ }^{85}$ ). 


\subsection{PREVALÊNCIA}

Inúmeros estudos epidemiológicos demonstram a alta prevalência das diversas formas de doenças periodontais em pessoas adultas e idosas, como também a alta prevalência de uma forma reversível de doença periodontal em pessoas mais jovens. Esta alta prevalência das doenças periodontais ocorre em diferentes populações e em todas as idades, variando na gravidade segundo a faixa etária, tipo de infecção, problemas sistêmicos e fatores de risco. As necessidades de tratamento e prevenção das doenças periodontais também têm sido amplamente pesquisadas no mundo. Parece não haver diferença de gravidade das doenças periodontais em países desenvolvidos com relação aos países em desenvolvimento. (Ainamo, $1988{ }^{1}$; Buckley \& Crowley, $1984^{22}$; Chiapinotto, $2000^{25}$; Cunha \& Chambrone, $1998^{31,32}$; Delaney, $1995^{33}$; Dibart, $1997{ }^{35}$; Hugoson et al., $1998^{47}$; Listgarten et al., $1985^{54}$; Löe \& Silness, $1963{ }^{57}$; Medeiros \& Carvalho, $1990{ }^{67}$; Norderyd \& Hugoson, 1998 72. Papapanou, $1996^{78}$; Papapanou \& Baelum, $1996{ }^{79}$; Papapanou \& Lindhe, 1999 ${ }^{80}$; Pinto, $1995^{83}$ ).

Estudos amplos citados por Chiapinotto (2000) ${ }^{25}$ demonstraram que nos Estados Unidos, em 1974, a proporção de pessoas sem qualquer sinal de doença periodontal foi $61 \%$ na faixa de 6-11 anos, $32 \%$ entre $12-17$ anos e $26 \%$ entre 18-79 anos.

Estudo epidemiológico realizado na zona urbana no Brasil em $1986^{19}$, demonstrou que o contingente de pessoas com periodonto saudável foi de $28 \%$ para a faixa de 15-19 anos, 15\% entre 35-39 anos e 4\% entre 60-64 anos. No grupo de 35 a 44 anos, $72 \%$ das pessoas eram sadias ou apresentavam sinais iniciais ou reversíveis da doença periodontal, 21,5\% tinham bolsas moderadas e 6,5\% tinham bolsas profundas. Este estudo constatou que $19 \%$ dos adultos entre 35 e 44 anos eram edêntulos, sendo $25 \%$ entre os mais pobres e 13,5\% entre os mais ricos. Em todas as faixas etárias as condições de saúde periodontal na população de baixa renda foram piores que as dos grupos economicamente mais favorecidos. 
Pinto (2000) ${ }^{83}$ considera que a doença periodontal é universal, e um dos principais problemas de saúde pública odontológica nos países pobres e também nos desenvolvidos.

Outros relatos também indicam sua alta prevalência em jovens: entre 16-20 anos, Medeiros \& Carvalho (1990) ${ }^{67}$ observaram uma prevalência inicial de $100 \%$ e de 42,9\% após 20 semanas de um programa de atenção periodontal. Entre adolescentes (11-13 anos) 80\% apresentavam gengivite, segundo Dibart (1997) ${ }^{35}$. Dados de Delaney (1995) ${ }^{33}$ mostraram prevalências de gengivite de 2 a $34 \%$ aos 2 anos, e de 18 a $38 \%$ aos 3 anos. Nesses grupos raramente a gengivite progride para periodontite, embora crianças e jovens também estejam sujeitos a doenças periodontais destrutivas. Fatores imunológicos e microbiológicos explicam a tendência de algumas crianças terem gengivite progredindo para periodontite, sendo que a transmissão dos microorganismos periodontopatogênicos ocorre da mãe para a criança no início da infância; quando ocorre periodontite em criança normalmente há história familiar de periodontite. Havendo o diagnóstico de periodontite pré-puberal sugere-se investigação quanto a doenças sistêmicas (Delaney, $1995^{33}$; Dibart, 1997 $\left.{ }^{35}\right)$.

Devido ao caráter comum desta modalidade de doença, isto já seria uma razão para uma parte significativa da população estar exposta às infecções associadas às doenças cardíacas. Atualmente a doença coronariana aterosclerótica é a principal causa de óbito na maioria dos países desenvolvidos, a despeito dos avanços preventivos e terapêuticos, o mesmo ocorrendo nos países em desenvolvimento. É, portanto, inquestionável a importância dos estudos epidemiológicos das patologias periodontais, visando compreender sua etiopatogenia e seus fatores de risco ou predisponentes, em particular os passíveis de modificação e tratamento. Associado a isto, têm-se os enormes ganhos sociais e financeiros que estes estudos podem proporcionar (Loesche, $1995^{59}$; Murray \& Lopez, $1997^{71}$; Page, $1998^{76}$; Williams \& Offenbacher, $\left.2000{ }^{103}\right)$. 


\subsection{CLASSIFICAÇÃO DAS DOENÇAS PERIODONTAIS}

As diversas formas de alterações periodontais são classificadas em doenças gengivais, (1) induzidas ou (2) não-induzidas pelo biofilme dental, e doenças periodontais (1) crônica, (2) agressiva, (3) como manifestação de doenças sistêmicas, (4) necrosantes, (5) na forma de abscessos, (6) associadas a lesões endodônticas, (7) como deformidade adquirida ou de desenvolvimento - os fatores dentários que podem predispor ou modificar as doenças periodontais são anatomia dentária, trauma oclusal, restaurações com discrepâncias marginais, fraturas dentárias, infecções endodônticas, reabsorção radicular externa e deformidades mucogengivais (A. A. P., $\left.1999^{98}\right)$.

Genericamente são classificadas em:

- gengivite: compromete os tecidos gengivais porém sem perda de inserção periodontal. Clinicamente pode ser caracterizada pela presença de sinais como vermelhidão, edema, sangramento provocado, alteração do contorno e consistência, presença de biofilme e/ou cálculo dental, e nenhuma comprovação radiográfica de perda da crista óssea alveolar. Pode ser modificada por alterações do sistema endócrino, medicamentos e subnutrição.

- periodontite: compromete também os tecidos de suporte ou sustentação do elemento dental, com a formação de bolsas periodontais e perda de inserção.

No grupo das periodontites, as formas crônica e agressiva (periodontite de estabelecimento precoce ou PEP) têm especificidades.

A periodontite crônica é mais prevalente em adultos; a destruição tecidual é condizente com os fatores locais presentes; freqüentemente há cálculo subgengival; o padrão microbiano é variável; a progressão é lenta ou moderada; pode estar associada a fatores predisponentes locais (iatrogenias ou fatores relacionados ao dente); pode estar associada ou ser modificada por doenças sistêmicas (diabetes , HIV); pode ser modificada por fatores como tabagismo e estresse. Sua prevalência e 
gravidade aumentam com a idade; pode afetar um número variável de dentes; seu início e manutenção dependem do biofilme dental; é plausível admitir que progredirá mais se um tratamento adequado não for instituído; segundo o número de sítios envolvidos pode ser descrita como localizada ou generalizada (quando mais de $30 \%$ dos sítios estão comprometidos pela doença); segundo sua gravidade pode ser classificada em leve (profundidade de sondagem de 1-2mm), moderada (3-4mm) e grave $(\geq 5 \mathrm{~mm})$. Por interferência de fatores identificáveis e não-identificáveis, nem todos os casos tem resultados favoráveis após a terapia; estes casos são denominados de periodontite refratária ou não-responsiva. As características clínicas primárias das periodontites incluem perda clínica de inserção, perda de osso alveolar, formação de bolsa periodontal e inflamação gengival, associados ou não a aumento ou recessão gengival, sangramento gengival, aumento da mobilidade dentária e esfoliação dos dentes envolvidos. Histologicamente é caracterizada pela proliferação apical do epitélio juncional, perda de fibras colágenas, presença de neutrófilos no epitélio da bolsa e no epitélio juncional, e um denso infiltrado de células inflamatórias (células plasmáticas, linfócitos e macrófagos).

A forma agressiva ou periodontite de estabelecimento precoce (PEP) apresenta características sindrômicas (representam manifestação oral de doenças sistêmicas; a idade de estabelecimento normalmente coincide com a puberdade; a gravidade da destruição é indicativa da virulência dos agentes etiológicos e da susceptibilidade do hospedeiro), etiológicas (em 90\% das lesões de pacientes com periodontite juvenil localizada foi detectado o Actinobacillus actinomicetemcomitans, constituindo o fator etiológico principal desta patologia) e genéticas (na maioria das vezes a quantia de biofilme não justifica a destruição periodontal existente, o que sugere a hipótese de que há uma maior susceptibilidade desses pacientes às doenças periodontais; há também a associação de fatores externos ou ambientais (tabagismo) e fatores internos ou endógenos como modificadores da resposta do hospedeiro; com a redução da migração e função antimicrobiana dos leucócitos - que podem ser herdados através de defeitos em um ou mais genes -, há redução da capacidade de produção de anticorpos específicos e protetores, o que faz com que as PEP se agreguem em algumas famílias). 
Estudos epidemiológicos indicam que as periodontites agressivas ou PEP são detectáveis em todas as idades e grupos étnicos. Löe e cols. (1986) ${ }^{56}$, após 20 anos de observação, relataram prevalência de $8 \%$ em população sem autocuidados e sem serviços de saúde bucal.

A terapia periodontal deve ser direcionada à supressão ou eliminação dos agentes etiológicos das doenças periodontais (Becker et al., $1979{ }^{18}$; Lindhe \& Nyman, $1988^{52}$; Löe, $1994^{55}$; Ong et al., $1998^{74}$; Westfelt et al., $1998^{102}$ ). Classificar a condição periodontal é útil para determinar o diagnóstico e para o desenvolvimento de terapias efetivas neste complexo grupo de infecções. 


\subsection{DOENÇA PERIODONTAL COMO FATOR DE RISCO PARA DOENÇAS SISTÊMICAS}

Recentes estudos têm demonstrado que as doenças periodontais, principalmente por seu caráter infeccioso, são fatores de risco para doenças sistêmicas (DeEstefano, $1993^{34}$; Genco, $1997^{39}$; Herzberg \& Meyer, $1998^{46}$; Joshipura et al., $1996^{48}$; Loesche, $1995^{59}$; Mattila et al., $1995^{64}$; Mealey, $1996^{66}$ ).

A presença ou ausência dos dentes e das bactérias que neles residem são fatores de risco potenciais para morte em idade precoce, acidente vascular cerebral (AVC), infarto agudo do miocárdio e morte prematura de bebês gerados por mães com doença periodontal avançada. A doença cardíaca é a condição mais comumente encontrada em pacientes com periodontite. Os fatores positivos da relação doença periodontal e doença cardiovascular são idade, raça, sexo, educação, nível socioeconômico, estado civil, peso corporal, pressão arterial, diabetes, fumo (Genco, $1996^{40}$; Morrison et al., $1999^{70}$; Paunio et al., $1993^{81}$; Wu et al., $2000^{104}$ ).

Loesche (1995) ${ }^{59}$ e Loesche et al. (1997) ${ }^{60}$ associaram doença cardiovascular e doença periodontal, com várias hipóteses explicativas; uma delas diz que o simples fato de escovar dentes em pacientes infectados pode produzir uma bacteriemia assintomática, que leva a um aumento de leucócitos e desencadeia uma séria de eventos de agregação plaquetária. Outra diz que algumas espécies bucais entram na corrente sangüínea durante o tratamento dentário. Consideram que os bons procedimentos de higiene bucal estimulam o sistema imune, com anticorpos para a microbiota normal; que a placa subgengival leva à invasão tecidual por lipopolissacárides (LPS) e citocinas, com aumento de monócitos hipersensíveis, levando à aterosclerose e eventos tromboembólicos. Consideram que a doença periodontal é um fator de risco independente para as doenças cardiovasculares, pois os doentes periodontais estão expostos às endotoxinas de muitas espécies de microorganismos anaeróbios associados com as doenças periodontais. Estas endotoxinas afetam a integridade do endotélio, as lipoproteínas do plasma, a coagulação sangüínea e a função plaquetária, sendo estes os fatores que podem levar a desenvolvimento de doença cardiovascular aterosclerótica. Essas observações 
enfatizam a necessidade de início precoce de programas preventivos, programas estes dirigidos às massas populacionais e aos diversos profissionais da saúde. Consideram que o manejo dos fatores de risco é hoje um importante componente da prevenção e tratamento das periodontites.

Papapanou (1996) ${ }^{78}$ e Papapanou \& Lindhe (1999) ${ }^{80}$ relataram que pacientes portadores de diabetes têm uma probabilidade três vezes maior de sofrer perda de tecido periodontal de suporte. Nos pacientes com diabetes de longa duração, início precoce e controle metabólico inadequado, há um risco elevado para a periodontite destrutiva. Reciprocamente, há evidências de que doenças periodontais inflamatórias são fatores de risco para doenças sistêmicas como diabetes e doenças cardiovasculares, e crianças com baixo peso ao nascer se geradas por mães com doença periodontal grave. Relataram a possibilidade de que as doenças periodontais e isquêmicas compartilhem algum caminho etiológico comum. Também que a gravidade das infecções odontológicas tem correlação com a extensão da ateromatose coronariana; que indivíduos que apresentam infecções odontológicas graves possuem altos níveis do fator antígeno de von Willebrand, leucócitos e fibrinogênio. Afirmam que descrever a prevalência e a incidência da doença periodontal traz informações valiosas para planejamentos de saúde bucal, mas que a tarefa principal é identificar fatores de risco para o desenvolvimento da doença, pois apesar de vários fatores já terem sido estabelecidos e ampla variedade de indicadores reconhecidos, o impacto das intervenções ainda está para ser documentado em estudos prospectivos.

Segundo Beck (1996) ${ }^{17}$ e Mealey (1996) ${ }^{66}$, esse grupo de doenças bucais também pode dificultar o controle metabólico dos níveis glicêmicos, em pacientes diabéticos. Isto é explicado pelo descontrole metabólico que ocorre nesses indivíduos frente a qualquer infecção orgânica.

Kinane \& Radvar (1997) ${ }^{49}$ e Ross (1999) ${ }^{90}$ relataram que as periodontites e a aterosclerose têm etiologia complexa, predisposição genética e de gênero, exibindo muitos fatores de risco, sendo o mais importante o tabagismo. Estas doenças também apresentam muitos mecanismos patogênicos comuns. Infecções e condições inflamatórias crônicas, como as periodontites, podem influenciar o processo 
aterosclerótico. Em comum com a doença periodontal, a patogênese da aterosclerose não está completamente estabelecida. $\mathrm{O}$ caráter crônico da doença periodontal provê uma origem farta de microorganismos subgengivais que, associados com os produtos da resposta do hospedeiro, produz efeitos por longo tempo. Os dois principais processos nas duas doenças são as citocinas produzidas pelos monócitos e os efeitos das lipopolissacárides (LPS) produzidas pelas bactérias; esses, tem efeito direto sobre o endotélio, com aumento dos níveis de fibrinogênio no plasma.

Morrison et al. (1999) ${ }^{70}$, Ross (1999) ${ }^{90}$ e Wu (2000) ${ }^{104}$ relataram que a doença periodontal pode ser considerado como fator de risco à problemas cardiovasculares e acidentes vasculares cerebrais (AVC). Afirmam que a "plausibilidade biológica" desta associação está no fato de que os mecanismos inflamatórios desencadeados pela infecção periodontal estimulam a formação de ateromas, responsáveis pelos eventos vasculares desencadeadores de isquemias coronarianas e cerebrais.

Offenbacher (1996) ${ }^{73}$ relata que a gravidez é uma condição que pode ser influenciada pela doença periodontal, havendo maior risco de nascimento de bebês prematuros e com baixo peso. Publicaram estudo epidemiológico demonstrando que mulheres com esta doença tinham maior risco de terem bebês prematuros e, conseqüentemente, com baixo peso, do que mulheres com periodonto saudável. $\mathrm{O}$ risco da doença periodontal nesta condição é comparável ao risco atribuível pelo tabagismo, reconhecido complicador dos eventos relacionados à gravidez. Isto pode ser explicado pelo fatos das citocinas inflamatórias presentes no processo periodontal, incluindo as prostaglandinas, terem a capacidade de induzir partos prematuros.

Em nosso meio são pouco frequientes estudos abordando as condições de saúde bucal, em geral, e da doença periodontal, em particular. Existe, assim, uma grande carência de dados relativos à essa doença, tanto em termos de distribuição e fatores de risco, bem como referentes à associação com doenças cardíacas isquêmicas. 


\section{OBJETIVOS}

Pretende-se com este estudo:

- $\quad$ estudar a prevalência da doença periodontal em pacientes com doença isquêmica coronariana aterosclerótica, atendidos na rotina do Hospital das Clínicas de Ribeirão Preto da Universidade de São Paulo (HCFMRP-USP);

- $\quad$ estudar a prevalência da doença periodontal em pacientes sem doença isquêmica coronariana aterosclerótica, atendidos na rotina do Hospital das Clínicas de Ribeirão Preto da Universidade de São Paulo (HCFMRP-USP);

- identificar o nível de informações sobre as doenças periodontais e cuidados em saúde bucal, em ambos os grupos. 


\section{CASUÍSTICA E MÉTODOS}

\subsection{POPULAÇÃO DE ESTUDO}

Foram compostos dois grupos de estudo:

- pacientes cardiopatas: composto de portadores de doença isquêmica coronariana aterosclerótica, com idade entre 30 e 79 anos, de ambos os sexos; e

- pacientes não-cardiopatas: composto de não-portadores de doença isquêmica coronariana aterosclerótica, com idade entre 30 e 79 anos, de ambos os sexos.

Para compor o grupo de pacientes cardiopatas foram selecionados os portadores de diagnóstico cardiológico dos grupos 124 e 125 da CID 10, no Ambulatório de Cardiologia do Hospital das Clínicas da Faculdade de Medicina de Ribeirão Preto - Universidade de São Paulo (HCFMRP-USP):

- 124 Outras doenças isquêmicas agudas do coração

- $\quad$ 124.0 Trombose coronária que não resulta em infarto do miocárdio

- 124.1 Síndrome de Dressler

- $\quad$ 124.8 Outras formas de doença isquêmica aguda do coração

- $\quad$ 124.9 Doença isquêmica aguda do coração não especificada

- 125 Doença isquêmica crônica do coração 
- $\quad$ 125.0 Doença cardiovascular aterosclerótica, assim descrita:

- $\quad$ 125.1 Doença aterosclerótica do coração

- $\quad$ 125.2 Infarto antigo do miocárdio

- 125.3 Aneurisma cardíaco

- $\quad$ 125.4 Aneurisma de artéria coronária

- $\quad$ 125.5 Miocardiopatia isquêmica

- $\quad$ 125.6 Isquemia miocárdica silenciosa

- $\quad$ 125.8 Outras formas de doença isquêmica crônica do coração

- $\quad$ 125.9 Doença isquêmica crônica do coração não especificada

Para compor o grupo de pacientes não-cardiopatas foram selecionados os pacientes do Ambulatório de Hepatites do HCFMRP-USP. O critério de exclusão de possíveis portadores de doença isquêmica coronariana aterosclerótica neste grupo de não-cardiopatas, foi a resposta positiva à pergunta "Algum médico já lhe disse que você tem ou teve ataque cardíaco, angina de peito ou doença coronariana?", formulada anteriormente à aplicação do questionário e exame bucal.

O recrutamento de pacientes para ambos os grupos foi realizado no período 15/04 à 19/09/2002. 


\subsection{CRITÉRIOS DE INCLUSÃO E EXCLUSÃO}

Foram utilizados como critérios de inclusão no estudo a presença de um mínimo de 20 dentes funcionais (excluídos os elementos dentais com estrutura comprometida pela cárie dentária e com extração indicada) e idade entre 30 e 79 anos.

Considerou-se que com um número mínimo de 20 dentes, seria possível avaliar-se a condição periodontal em pelo menos 5 sextantes. Este fato propiciaria a análise periodontal em indivíduos com dentição funcional mais preservada e menos comprometida por reabilitações restauradora e protética fixa, com potencial iatrogênico e desencadeador dos fenômenos típicos da doença periodontal. Quanto a idade entre 30 e 79 anos, considerou-se que dificilmente se encontraria pacientes com doença isquêmica coronariana aterosclerótica com idade menor que 30 anos, e que os pacientes com mais de 79 anos também dificilmente apresentariam dentes remanescentes no número mínimo estabelecido dada as características gerais da clientela do Ambulatório de Cardiologia do HCFMRP-USP.

Foram excluídos da avaliação periodontal os pacientes que, mesmo contemplando os critérios de idade e número de dentes, relataram histórico de endocardite bacteriana ou cardiopatia congênita ou reumática; condição de portador de HIV; pacientes que não quiseram participar permitindo o exame bucal; pacientes que apresentavam dentes inadequados ao exame (raízes residuais); pacientes que não poderiam responder adequadamente as perguntas formuladas (com histórico de acidente vascular cerebral (AVC), por exemplo, se desacompanhados ou sem condições de participar); pacientes com dificuldade de locomoção até a sala destinada ao exame; presidiários, por questões de segurança no deslocamento e exame; pacientes procedentes de outros municípios que não poderiam destinar tempo ao exame e que não poderiam retornar para exame em outro dia e local. 


\subsection{INDICADORES DAS CONDIÇÕES DE SAÚDE BUCAL}

Para se conhecer a distribuição e a gravidade das doenças periodontais nas populações em estudo, utilizou-se o sistema recomendado atualmente pela OMS ${ }^{75}$, descrito no manual Levantamentos Básicos em Saúde Bucal, $4^{\text {a }}$ edição, de $1999{ }^{75}$. Este sistema é constituído pelo Índice Periodontal Comunitário (IPC) e pela avaliação da Perda de Inserção periodontal (PI). 


\subsection{1 ÍNDICE PERIODONTAL COMUNITÁRIO (IPC)}

Através do Índice Periodontal Comunitário (IPC) avalia-se três indicadores das condições atuais do periodonto: (1) sangramento gengival, (2) cálculo dentário e (3) bolsas periodontais.

Utiliza-se sonda idealizada para o exame periodontal, que é um instrumento leve, apresentando na extremidade uma esfera de $0,5 \mathrm{~mm}$, com uma faixa ou tarja preta entre 3,5 e 5,5mm e anéis ou marcas aos 8,5 e 11,5mm.

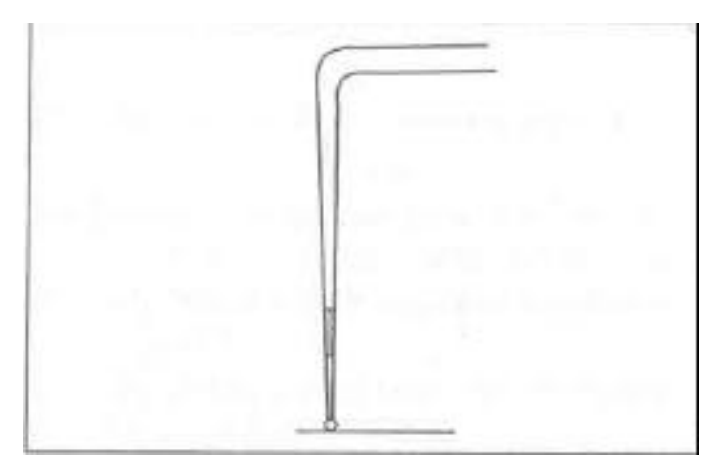

Figura 2 - Sonda preconizada pela OMS para exame periodontal (IPC e Perda de Inserção), com extremidade esférica de $0,5 \mathrm{~mm}$, uma faixa ou tarja preta entre 3,5 e 5,5mm e anéis ou marcas aos 8,5 e 11,5mm.

(Ilustração extraída do livro Levantamentos Básicas em Saúde Bucal, Organização Mundial da Saúde, cap. 5, p. 35, Formulário de Avaliação. São Paulo: Santos, $19999^{75}$ )

A técnica de sondagem envolve pressão não superior a 20 gramas, e com o instrumento paralelo à superfície dentária, tangenciando-a. O posicionamento inadequado leva à incorreta mensuração, além de provocar desconforto ao paciente. 


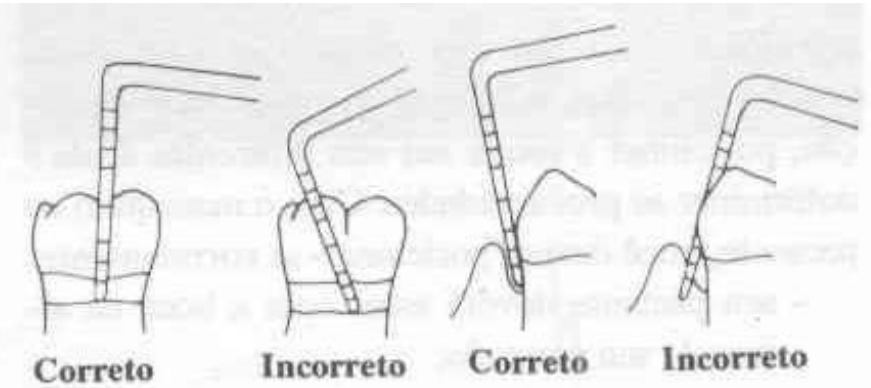

Figura 3 - Método de sondagem periodontal, com exemplos de posicionamento correto e incorreto da sonda.

(Ilustração extraída do livro Instrumentação em Periodontia - Orientações Clínicas, de PattisonPattison, cap. 2, p. 17, Introdução à Instrumentação: Utilização da Sonda Periodontal. São Paulo: Panamericana, 1988)

Quando se pratica a sondagem do sulco gengival ou da bolsa periodontal, o instrumento sensor penetra até onde o tecido gengival não oferece resistência à pouca pressão praticada no sentido apical. Em presença do infiltrado inflamatório no tecido gengival, a sonda penetra até a porção apical da bolsa histológica. Após tratamento periodontal e controle do fator etiológico primário da doença periodontal - biofilme dental -, o edema gengival diminui podendo produzir a recessão gengival, e a inflamação é substituída por colágeno; neste caso a sonda não alcança a adesão epitelial e se tem um falso ganho de inserção ou "inserção clínica". 


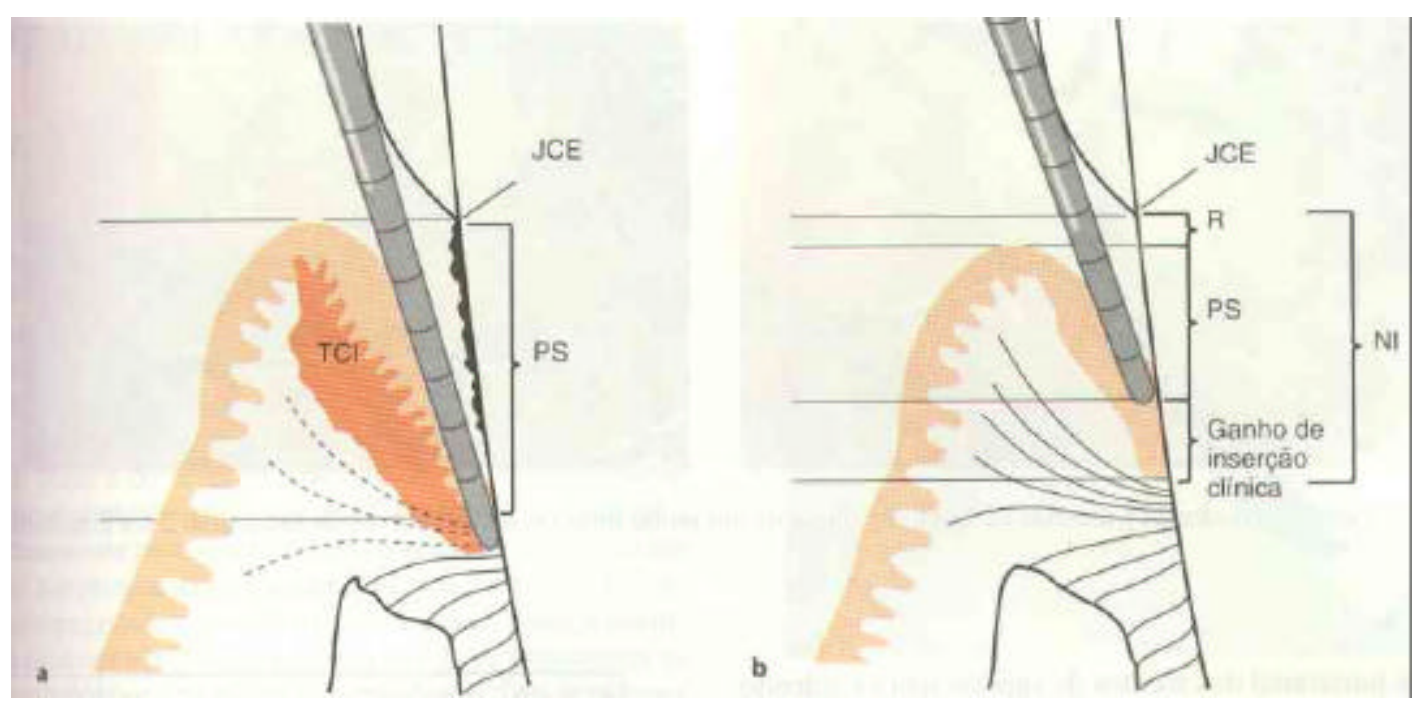

Figura 4 - Na presença de um infiltrado inflamatório ( $\mathrm{TCI}=$ tecido conjuntivo inflamado) na gengiva, a sonda penetra até a porção apical da bolsa histológica (a). Após tratamento, o edema diminui ( $\mathrm{R}$ = recessão) e a inflamação é substituída por colágeno (b); a sonda falha em alcançar a adesão epitelial. JCE ou JAC = junção amelocementária; PS = profundidade de sondagem; NI = nível de inserção; R = recessão gengival; Ganho NI = falso ganho de inserção ou "inserção clínica".

(Figura extraída do livro Tratado de Periodontia Clínica e Implantologia Oral, de Jan Lindhe, cap. 12, p. 275, Exame em pacientes com doença periodontal, de S. Nyman, J. Lindhe. Rio de Janeiro: Guanabara Koogan, 1997)

Na sistemática de exame periodontal, a dentição é dividida em seis partes ou sextantes, definidos pelos dentes 18-14, 13-23, 24-28, 38-34, 33-43 e 44-48. Um sextante deve ser examinado somente se houver dois ou mais dentes presentes, sem indicação de extração. Os dentes indicadores a serem examinados, para adultos com idade de 20 anos ou mais, são:

\begin{tabular}{ll|l|ll}
17 & 16 & 11 & 26 & 27 \\
\hline 47 & 46 & 31 & 36 & 37
\end{tabular}


Nesta pesquisa, os sextantes foram denominados de superior direito (SD), superior anterior (SA), superior esquerdo (SE), inferior direito (ID), inferior anterior (IA) e inferior esquerdo (IE).

Os dois molares em cada sextante foram emparelhados para o registro e, caso um estivesse ausente, não houve substituição. Caso não houvessem dentes indicadores presentes em um sextante qualificado para o exame, todos os dentes remanescentes naquele sextante foram examinados e o índice mais alto registrado como o índice do sextante, com exceção das superfícies distais dos terceiros molares.

No exame, os dentes indicadores são sondados utilizando-se a sonda periodontal como instrumento sensor na determinação da profundidade da bolsa periodontal, na detecção de cálculos dentários subgengivais e na verificação da presença de sangramento à sondagem. A força de sondagem não deve ser superior a 20 gramas, movimentando-se a sonda ao longo da superfície cervical dos dentes, com a ponta esférica inserida no sulco gengival e sondando toda a extensão deste sulco. Inicia-se pela superfície disto-vestibular do segundo molar, mantendo-se a sonda paralela ao longo eixo do dente, com movimentos curtos e suaves, para cima e para baixo, ao longo do sulco vestibular até a superfície mesial deste dente, prosseguindo pela superfície distal, vestibular e mesial do primeiro molar. Procedimento semelhante é executado nas superfícies linguais e palatinas.

Os dentes indicadores, ou todos os dentes remanescentes no sextante quando não houver dente indicador, devem ser sondados e o índice mais alto registrado.

Os códigos previstos no Índice Periodontal Comunitário ou IPC são:

- 0 - hígido [saúde periodontal]

- 1 - sangramento observado, diretamente ou pela utilização de um espelho clínico, após a sondagem

- 2 - cálculos detectados durante a sondagem, mas toda a tarja preta da sonda está visível 
- 3 - bolsa periodontal de 4-5mm, e margem gengival sobre a tarja preta da sonda

- 4 - bolsa periodontal de $6 \mathrm{~mm}$ ou mais, e tarja preta da sonda não visível

- $\mathrm{X}$ - sextante excluído por ter menos de dois dentes presentes

- - não registrado

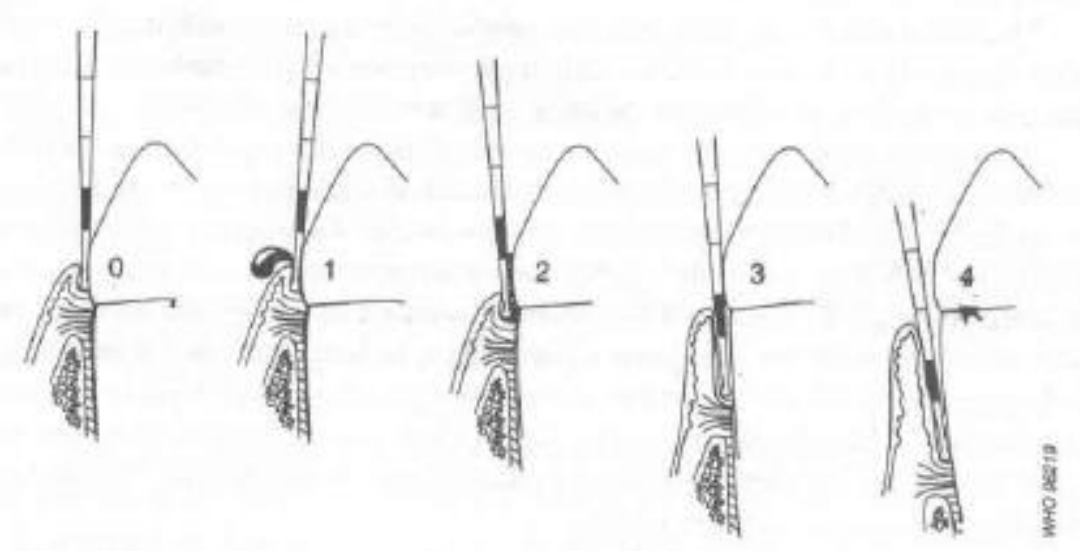

Figura 5 - Exemplos da codificação do IPC, e da posição da sonda periodontal.

(Figura extraída do livro Levantamentos Básicas em Saúde Bucal, Organização Mundial da Saúde, cap. 5, p. 38, Formulário de Avaliação. São Paulo: Santos, $1999^{75}$ )

No momento do exame periodontal, uma vez obtido o escore do IPC que traduz a condição mais grave observada para cada sextante, este é registrado. No entanto, isso não exclui que os demais escores do índice (representativos de condições de menor gravidade) não tenham sido observados. Portanto, na análise dos resultados deve-se considerar cada escore como indicativo isolado, sem desconsiderar que outras condições podem ser também encontradas. 


\subsubsection{PERDA DE INSERÇÃO PERIODONTAL}

A Perda de Inserção periodontal é coletada nos mesmos dentes indicadores, e objetiva estimar a destruição acumulada durante a vida útil da inserção periodontal. Tem como referência a junção amelocementária (JAC), que fica exposta ou visível quando ocorre recessão gengival. Permite comparações entre grupos populacionais, sem pretender descrever a extensão total da perda de inserção de um indivíduo. É registrada imediatamente após o registro do IPC, em cada sextante. Os valores mais altos para o IPC e a perda de inserção podem não ser encontrados na mesma superfície dentária em um sextante. A perda de inserção não deve ser registrada em indivíduos abaixo de 15 anos.

A extensão da perda de inserção é registrada utilizando-se os códigos:

- 0 - perda de inserção de 0-3 mm (JAC não visível e valor do IPC de 0-3)

Caso a JAC não seja visível e o valor do IPC seja 4, ou se a JAC for visível:

- 1 - perda de inserção de 4-5 mm (JAC dentro da tarja preta)

- 2 - perda de inserção de 6-8 mm (JAC entre o limite superior da tarja preta e o anel de $8,5 \mathrm{~mm}$ )

- 3 - perda de inserção de 9-11 mm (JAC entre os anéis de 8,5 e 11,5 mm)

- 4 - perda de inserção de $12 \mathrm{~mm}$ ou mais (JAC além do anel de 11,5 mm)

- $\mathrm{X}$ - sextante excluído (menos de dois dentes presentes)

- 9 - não registrado (JAC não visível ou detectável) 


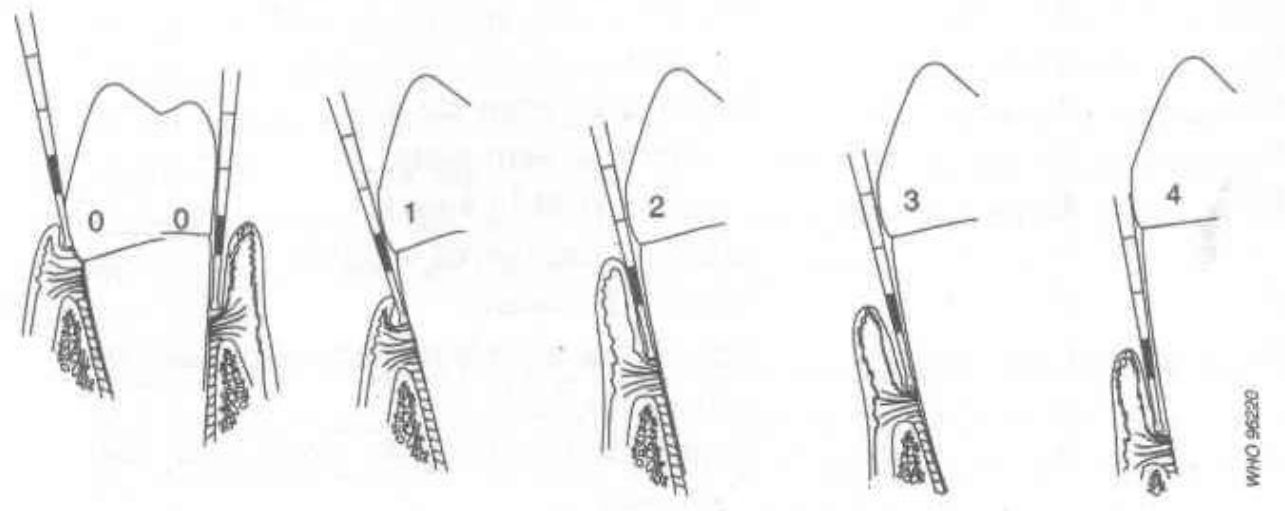

Figura 6 - Exemplos da codificação para a perda de inserção periodontal, com a sonda IPC.

(Figura extraída do livro Levantamentos Básicas em Saúde Bucal, Organização Mundial da Saúde, cap. 5, p. 39, Formulário de Avaliação. São Paulo: Santos, $1999^{75}$ ) 


\subsection{COLETA DAS INFORMAÇÕES}

Os pacientes foram previamente entrevistados no ambiente do consultório médico, no momento de sua consulta regularmente agendada.

Neste primeiro contato com os pacientes, foram coletados dados preliminares como "nome, idade, sexo, cor da pele, procedência, número de dentes na maxila, número de dentes na mandíbula, e necessidades bucais observadas".

Este contato inicial com os pacientes de ambos os grupos foi necessário para se identificar os potenciais participantes na pesquisa, ou seja, os que atendiam os critérios de inclusão (idade entre 30 e 79 anos e número mínimo de 20 dentes em condições de exame). Neste contato inicial com os pacientes de ambos os grupos, todos foram orientados segundo as necessidades bucais observadas.

Se os pacientes pré-selecionados preenchessem os critérios de inclusão, eram informados sobre as razões da pesquisa e convidados a dela participar. Em concordando, o exame bucal foi realizado em outro ambiente, que contemplou os requisitos de iluminação e privacidade. $\mathrm{O}$ termo de consentimento livre esclarecido, assinado pelos pacientes que concordaram em participar do estudo, está apresentado no Anexo B.

Se não preenchessem os critérios de inclusão, eram orientados quanto as suas necessidades bucais e sobre a importância de manter as estruturas bucais em condições de saúde.

Os pacientes incluídos inicialmente no grupo teste (18 de um total de 58 pacientes) foram examinados em consultório particular devido à dificuldade de se conseguir espaço para exame bucal no HCFMRP-USP. Este espaço somente foi conseguido após 2 meses de exaustivas tentativas de persuadir os pacientes potenciais participantes a se deslocarem até o consultório onde se faria o exame bucal. Os pacientes que se dispuseram a se deslocar até o local de exame, após este receberam procedimentos de remoção de cálculo dentário com a utilização de aparelho de ultra-som, orientações quanto a dinâmica da doença periodontal, e 
instruções quanto aos procedimentos, métodos e dispositivos de higiene bucal. Todos foram examinados por um cirurgião-dentista. Foram orientados quanto a necessidade de dar seqüência ao tratamento periodontal em local de seu acesso e conveniência.

O exame bucal no HCFMRP-USP, dos pacientes rotineiramente atendidos e considerados elegíveis para este estudo foi realizado também por um único cirurgiãodentista examinador, com instrumental padronizado para o exame bucal, em local adequado em relação à iluminação, assepsia, privacidade etc., em área próxima aos ambulatórios de rotina dos pacientes selecionados.

Planejou-se examinar 100 pacientes de cada grupo, perfazendo um total de 200 exames. Porém, dificuldades de recrutamento dos pacientes cardiopatas com número mínimo de 20 dentes e ausência de tempo hábil para emparelhamento por idade entre os pacientes não-cardiopatas, alteraram o planejamento inicial quanto ao tamanho e a composição da amostra.

No Ambulatório de Cardiopatia Isquêmica, o tamanho da amostra de pacientes cardiopatas foi reduzido, pois apenas $16,7 \%$ dos pacientes apresentaram o número de dentes considerado mínimo; foram avaliados preliminarmente 480 pacientes, sendo que 80 foram considerados elegíveis por contemplar os critérios de inclusão. No entanto, somente $58(12,1 \%)$ foram incluídos no estudo por não apresentarem um ou mais dos critérios de exclusão. Foram necessárias 21 semanas, distribuídas no período de 15/04/02 a 16/09/02, para se atingir a amostra final deste grupo.

No Ambulatório de Hepatites, a composição da amostra de pacientes nãocardiopatas foi prejudicada quanto ao emparelhamento, pois a idade dos pacientes foi significativamente menor. Foram avaliados preliminarmente 154 pacientes, sendo 71 considerados elegíveis (46,10\%), e 62 pacientes (40,25\%) incluídos no estudo. Respeitou-se os mesmos critérios de inclusão e exclusão do grupo de pacientes cardiopatas. Foram necessárias 8 semanas, distribuídas no período de 01/08/02 a 19/09/02, para se atingir a amostra final deste grupo. 
Anteriormente ao exame bucal propriamente dito, procedeu-se à coleta de informações gerais.

As variáveis gerais investigadas em ambos os grupos foram: idade (em anos completos no dia do exame bucal); sexo (masculino ou feminino); procedência (município e Estado); ocupação; cor da pele (branco, negro, pardo, amarelo); escolaridade (não estudou, $1^{\circ}$ grau incompleto, $1^{\circ}$ grau completo, $2^{\circ}$ grau incompleto, $2^{\mathrm{o}}$ grau completo, superior incompleto, e superior completo); tabagismo (nunca fumou, fumante de menos de 10 cigarros ao dia, fumante de 10 a 20 cigarros ao dia, fumante de 20 a 30 cigarros ao dia, fumante de mais de 30 cigarros ao dia, exfumante); tempo de tabagismo (em anos; para fumantes e ex-fumantes); se recebeu orientação sobre métodos e dispositivos de higiene bucal (sim ou não); se orientado, por quem (dentista, família, escola ou outra instituição, leu a respeito, outra fonte); prática diária de escovação (sim ou não); número de escovações ao dia (1 vez, 2 vezes, 3 vezes, 4 ou mais vezes); tipo de escova (dura, média, macia/extra macia, não sabe); tempo aproximado gasto com a escovação (em minutos; escovação que o paciente considera a mais importante do dia e executa com mais capricho); troca da escova (em dias para as pessoas que recordam o tempo de troca, ou segundo outros critérios para as pessoas que não recordam o tempo de troca - perda, quebra, aspecto das cerdas, não sabe); uso individual ou familiar/coletivo da escova dental; uso de fio/fita dental (não usa, usa às vezes, usa diariamente); uso de creme dental (antitártaro, com triclosan, comum, variados, outro, não usa); uso de enxagüatório bucal (não usa, usa às vezes, usa diariamente); tipo de enxagüatório bucal (para quem usa às vezes e diariamente, segundo o tipo - clorexedina, listerine, triclosan, cetilperidínio, própolis, água oxigenada, flúor, solução caseira, outro); uso de acessório de higiene bucal (sim ou não); tipo de acessório (para quem usa, segundo o tipo - escova interproximal, escova bitufo, waterpick, massageadores gengivais, limpador de língua, palito dental, outro); consumo de álcool (todos os dias, 5 a 6 dias por semana,, 3 a 4 dias por semana, 1 a 2 dias por semana, 3 a 4 dias ao mês, 1 a 2 dias ao mês, menos de 1 dia ao mês, nunca consumiu, consumiu no passado); doenças de interesse à periodontia (diabetes, acidente vascular cerebral (AVC), hipertensão arterial, outra); uso contínuo de medicação (sim ou não; para quem usa, segundo o tipo - anticoagulante, antiagregante plaquetário, fenitoína, outra, não 
sabe); conhecimento prévio sobre a existência de doença periodontal (não sabe que existem doenças periodontais, sabe porque alguém da família ou de suas relações tem, sabe porque recebeu orientações específicas ou de profissionais da área, sabe porque leu a respeito, acha que tem este tipo de problema, acha que é invenção, outro); acesso e indicação da Terapia Periodontal Básica (não fez, faz eventualmente, faz rotineiramente, outro); acesso e indicação da Terapia Periodontal Complexa (nunca fez/nunca indicada, indicada e não realizada, realizada conforme indicação); acesso e indicação da Terapia Periodontal de Manutenção (não faz, indicada e não realizada, realizada conforme indicação); queixas bucais referidas ( $\operatorname{sim}$ ou não; se sim, segundo o tipo de queixa - dor, cárie dentária, doença periodontal, lesões de tecidos moles da boca, estética, decorrentes do uso de prótese, decorrentes da falta de dentes/edentulismo, fonética, hábito parafuncional [considerar bruxismo, apertamento dental, roer unha ou outros objetos], sensibilidade na ingestão de alimentos/líquidos frios, quentes e doces, decorrentes da maloclusão ou posicionamento atípico de dentes, outras queixas).

O exame bucal foi realizado utilizando-se espelho bucal plano e sonda periodontal recomendada pela OMS; permitiu coletar informações importantes na dinâmica da doença periodontal bem como do grau de saúde-doença periodontal.

As variáveis bucais investigadas em ambos os grupos foram: número total de dentes e por sextante; presença e tipo de fatores de retenção de biofilme dental (cárie dentária, cálculo, restauração/prótese insatisfatória, outro fator - apinhamento dental); codificações, segundo o sextante, do Índice Periodontal Comunitário (IPC) e da Perda de Inserção (PI) periodontal; e necessidades bucais observadas segundo a área ou especialidade odontológica (sim ou não; se sim, segundo a área - prótese, periodontia, endodontia, cirurgia para exodontia de dentes ou raízes, orientações para exames rotineiros preventivos de câncer bucal, dentística, outra - ortodontia etc.); local do exame bucal (HCFMRP-USP ou consultório particular).

Foram utilizados formulários próprios, desenvolvidos para a coleta dos dados (Anexo A) e para o consentimento livre do paciente para exame bucal e participação na pesquisa (Anexo B). 


\subsection{DIGITAÇÃO E ANÁLISE DOS DADOS}

As informações foram codificadas e digitadas pela própria autora da investigação, criando-se um banco de dados no Programa EpiInfo 6.0. Posteriormente, foram transportadas para o Programa Stata 6.0 para análise. Esta foi realizada mediante a utilização do teste do qui-quadrado para verificar associação entre variáveis qualitativas ou entre variáveis quantitativas agrupadas. Nas situações em que o reduzido tamanho amostral impediu a utilização do teste qui-quadrado, usou-se o teste exato de Fisher. Em todas as situações, o limite de significância estatística adotado foi igual a 0,05 . 


\section{RESULTADOS}

A fase de recrutamento dos pacientes gerou informações elucidativas das condições gerais de saúde bucal nos dois grupos estudados e os exames clínicos realizados permitiram obter resultados da investigação periodontal propriamente dita.

\subsection{RECRUTAMENTO DOS PACIENTES}

Foram examinados nesta fase, para verificar se atendiam o primeiro critério de inclusão na pesquisa periodontal (mínimo de 20 dentes funcionais), um total de 634 pacientes, sendo 480 do grupo de cardiopatas e 154 do grupo de não-cardiopatas.

Do total de 480 pacientes cardiopatas, 62,5\% são do sexo masculino e 37,5\% do feminino. As idades variaram de 33 a 86 anos nos homens, e de 32 a 86 anos nas mulheres. A média e a mediana de idade foram respectivamente 61,8 e 62,5 anos, sendo que $405(84,4 \%)$ pessoas tinham mais de 50 anos.

Do total de 154 pacientes não-cardiopatas, 66,2\% são do sexo masculino e $33,8 \%$ do feminino. As idades variaram de 21 a 61 anos nos homens, e de 17 a 64 anos nas mulheres. A média e a mediana de idade foram respectivamente 41,0 e 40,0 anos, sendo que $117(76,0 \%)$ pessoas tinham menos de 50 anos.

A tabela 1 ilustra a distribuição dos pacientes segundo faixa etária e sexo, em ambos os grupos. 
Tabela 1 - Distribuição de pacientes cardiopatas e não-cardiopatas, segundo idade e sexo. HCFMRP-USP, 2002.

\begin{tabular}{|c|c|c|c|c|c|c|c|c|c|c|}
\hline \multirow{4}{*}{$\begin{array}{l}\text { Grupo } \\
\text { etário }\end{array}$} & \multicolumn{8}{|c|}{ Grupo } & & \\
\hline & & ARDIC & PAT & & \multirow{2}{*}{\multicolumn{4}{|c|}{$\begin{array}{l}\text { NAO-CARDIOPATAS } \\
\text { Masculino } \quad \text { Feminino }\end{array}$}} & \multirow{2}{*}{\multicolumn{2}{|c|}{ Total }} \\
\hline & \multicolumn{2}{|c|}{ Masculino } & \multicolumn{2}{|c|}{ Feminino } & & & & & & \\
\hline & $\mathrm{n}$ & $\%$ & $\mathrm{n}$ & $\%$ & $\mathrm{n}$ & $\%$ & $\mathrm{n}$ & $\%$ & $\mathrm{n}$ & $\%$ \\
\hline$<30$ & - & - & - & - & 12 & 11,8 & 12 & 23,1 & 24 & 3,8 \\
\hline $30-34$ & 3 & 1,0 & 1 & 0,6 & 17 & 16,7 & 9 & 17,3 & 30 & 4,7 \\
\hline $35-39$ & 6 & 2,0 & 4 & 2,2 & 16 & 15,7 & 5 & 9,6 & 31 & 4,9 \\
\hline $40-44$ & 19 & 6,3 & 6 & 3,3 & 19 & 18,6 & 6 & 11,5 & 50 & 7,9 \\
\hline $45-49$ & 26 & 8,7 & 10 & 5,6 & 17 & 16,7 & 4 & 7,7 & 57 & 9,0 \\
\hline $50-54$ & 36 & 12,0 & 23 & 12,8 & 10 & 9,8 & 6 & 11,5 & 75 & 11,8 \\
\hline $55-59$ & 45 & 15,0 & 15 & 8,3 & 8 & 7,8 & 3 & 5,7 & 71 & 11,2 \\
\hline $60-64$ & 44 & 14,7 & 22 & 12,2 & 2 & 2,0 & 6 & 11,5 & 74 & 11,7 \\
\hline $65-69$ & 42 & 14,0 & 43 & 23,9 & 1 & 1,0 & 1 & 1,9 & 87 & 13,7 \\
\hline $70-74$ & 42 & 14,0 & 31 & 17,2 & - & - & - & - & 73 & 11,5 \\
\hline $75-79$ & 22 & 7,3 & 16 & 8,9 & - & - & - & - & 38 & 6,0 \\
\hline $80 \mathrm{e}+$ & 15 & 5,0 & 9 & 5,0 & - & - & - & - & 24 & 3,8 \\
\hline Total & 300 & 100,0 & 180 & 100,0 & 102 & 100,0 & 52 & 100,0 & 634 & 100,0 \\
\hline
\end{tabular}

Os achados relativos ao número agrupado de dentes em ambas as arcadas dentários revelam que, entre os pacientes cardiopatas, 237 pessoas $(49,4 \%)$ se apresentaram edêntulas, $160(33,3 \%)$ com 1 a 19 dentes, $34(7,1 \%)$ com 20 a 24 dentes, $35(7,3 \%)$ com 25 a 28 dentes e $14(2,9 \%)$ com 29 a 32 dentes. Das 480 pessoas examinadas, $397(82,7 \%)$ não apresentavam e $83(17,3 \%)$ apresentavam suficiente número de dentes naturais hígidos e/ou restaurados, para aparentemente estar exercendo suas funções bucais sem necessidades, ou grandes necessidades, de intervenções para reabilitação bucal.

A distribuição de pessoas segundo o número agrupado de dentes em ambas as arcadas dentárias, entre os pacientes não-cardiopatas, revelam achados substancialmente diferentes do observado no grupo de pacientes cardiopatas. 
Observou-se que 10 pessoas (6,5\%) eram edêntulas, 48 (31,2\%) com 1 a 19 dentes, $19(12,3 \%)$ com 20 a 24 dentes, $45(29,2 \%)$ com 25 a 28 dentes, 32 (20,8\%) com 29 a 32 dentes. Dos 154 pacientes examinados, 56 (37,7\%) não apresentavam e 96 $(62,3 \%)$ apresentavam suficiente número de dentes naturais hígidos e/ou restaurados, para aparentemente exercer suas funções mastigatória, fonética e estética sem necessidades ou grandes necessidades para reabilitação bucal.

A tabela 2 demonstra os achados do número agrupado de dentes em ambas as arcadas dentárias, nos dois grupos estudados.

Tabela 2 - Distribuição do número agrupado de dentes em pacientes cardiopatas e não-cardiopatas. HCFMRP-USP, 2002.

\begin{tabular}{c|rrrr}
\hline \multirow{2}{*}{ Número de dentes } & \multicolumn{2}{|c}{ CARDIOPATAS } & \multicolumn{2}{c}{ NÃO-CARDIOPATAS } \\
& $\mathrm{n}$ & \multicolumn{1}{c}{$\%$} & $\mathrm{n}$ & $\%$ \\
\hline 0 & 237 & 49,4 & 10 & 6,5 \\
$1-5$ & 24 & 5,0 & 3 & 2,0 \\
$6-10$ & 73 & 15,2 & 19 & 12,3 \\
$11-19$ & 63 & 13,1 & 26 & 16,9 \\
$20-24$ & 34 & 7,1 & 19 & 12,3 \\
$25-28$ & 35 & 7,3 & 45 & 29,2 \\
$29-32$ & 14 & 2,9 & 32 & 20,8 \\
\hline Total & 480 & 100,0 & 154 & 100,0 \\
\hline
\end{tabular}

Conforme mostra a tabela 3, observou-se necessidades nas áreas ou especialidades odontológicas. Dos 480 pacientes cardiopatas estudados, somente 1 $(0,2 \%)$ apresentou-se com a boca em condições funcionais e conhecedor da necessidade de exames bucais preventivos rotineiros, 58,8\% com necessidade de prótese, $41,7 \%$ de periodontia, $10,6 \%$ de cirurgia/exodontia, 14,4\% de dentística e 93,3\% de informações quanto ao exame preventivo de câncer bucal. Dos 154 pacientes não-cardiopatas, 37,7\% necessitam de prótese, $59,7 \%$ de periodontia, 13,6\% de cirurgia/exodontia (na grande maioria, para remoção de terceiros molares), 14,9\% de dentisteria, 43,5\% de orientações quanto à necessidade de exames 
preventivos rotineiros, $3,2 \%$ de procedimentos em outras áreas (ortodontia etc.) e $18,8 \%$ não apresentam necessidades bucais.

Tabela 3 - Distribuição das necessidades bucais de pacientes cardiopatas e nãocardiopatas, segundo área ou especialidade odontológica. HCFMRP-USP, 2002.

\begin{tabular}{l|rrrr}
\hline & \multicolumn{3}{|c}{ CARDIOPATAS } & \multicolumn{2}{c}{ NÃO-CARDIOPATAS } \\
Área ou especialidade & $\mathrm{n}$ & \multicolumn{1}{c}{$\%$} & $\mathrm{n}$ & \multicolumn{1}{c}{$\%$} \\
\hline Prótese & 282 & 58,8 & 58 & 37,7 \\
Periodontia & 200 & 41,7 & 92 & 59,7 \\
Endodontia & 2 & 0,4 & - & - \\
Cirurgia & 51 & 10,6 & 21 & 13,6 \\
Orientações para prevenção & 448 & 93,3 & 67 & 43,5 \\
$\quad$ de câncer bucal & & & & \\
Dentística & 69 & 14,4 & 23 & 14,9 \\
Outras áreas & 1 & 0,2 & 5 & 3,2 \\
Sem necessidades & 1 & 0,2 & 29 & 18,8 \\
\hline$\quad$ Total de pacientes & 480 & 100,0 & 154 & 100,0 \\
\hline
\end{tabular}

Embora não apresentados em tabelas, os resultados permitiram classificar as pessoas segundo:

- $\quad$ procedência: observou-se que 172 pacientes cardiopatas (35,8\%) são procedentes de Ribeirão Preto-SP, 154 (32,1\%) dos demais municípios da DIR XVIII, 89 (18,6\%) de outros municípios do Estado de São Paulo, 64 (13,3\%) do Estado de Minas Gerais, e 1 (0,2\%) do Estado de Alagoas. Entre os pacientes nãocardiopatas, observou-se que 64 (41,6\%) são procedentes de Ribeirão Preto-SP, 37 (24,0\%) dos demais municípios da DIR XVIII, 40 (26,0\%) de outros municípios do Estado de São Paulo, e 13 (8,4\%) do Estado de Minas Gerais.

- necessidade de cirurgia/exodontia segundo o número de dentes presentes: observou-se que dos 51 pacientes cardiopatas que necessitam de exodontia, 35 são portadores de menos de 20 dentes $(68,6 \%)$. Entre os pacientes não-cardiopatas, a esmagadora maioria dos que necessitam de exodontia tem 20 ou mais dentes $(76,2 \%)$, sendo que esta indicação visou primordialmente a remoção de terceiros molares. 
- $\quad$ necessidade de prótese segundo o número de dentes presentes: observouse que, dos 282 pacientes cardiopatas que necessitam de reabilitação, $245(86,9 \%)$ possuem de zero a 19 dentes, e não utilizavam próteses ou estas se encontravam em condições inadequadas para uso no momento do exame. Dos 58 pacientes nãocardiopatas que necessitam de algum tipo de prótese, $39(67,2 \%)$ tem de zero a 19 dentes presentes, fato que retrata a não utilização, ou a inadequada condição da prótese para quem a necessita. Foi comum no relato de portadores de prótese total de ambos os grupos estudados, o desconhecimento da necessidade de troca periódica das peças, motivada pelo desgaste dos dentes e pela reabsorção do rebordo alveolar, que facilita o deslocamento da peça e o traumatismo constante dos tecidos moles.

Dos 480 pacientes cardiopatas, 83 tinham 20 ou mais dentes, porém somente $80(16,7 \%)$ foram classificados como elegíveis para compor o grupo no qual as condições periodontais seriam investigadas. Os 3 pacientes excluídos o foram por apresentar menos de 20 dentes em condições de serem mantidos na cavidade bucal; observou-se nestes pacientes grande número de raízes residuais, inadequadas para avaliação periodontal e com exodontia indicada.

Dos 154 pacientes não-cardiopatas, $71(46,1 \%)$ foram classificados como elegíveis para compor o grupo no qual as condições periodontais seriam investigadas. Desses, 9 pacientes foram excluídos por apresentar algum dos fatores de exclusão (HIV, não querer participar do estudo etc.), resultando 62 participantes. 


\subsection{INVESTIGAÇÃO PERIODONTAL}

Dos 80 pacientes cardiopatas elegíveis, 58 (72,5\%) puderam ser incluídos e ter as condições periodontais investigadas. Esta amostra corresponde a $12,1 \%$ do grupo de 480 pacientes inicialmente examinado. Foram excluídos 22 pacientes da investigação periodontal, pelos seguintes motivos: 14 justificaram não ter possibilidade de se deslocar até o consultório na fase inicial da coleta de dados (quando não se dispunha de área física no HCFMRP-USP); 3 por não quererem participar; 3 por não disporem de tempo; 1 por apresentar sequelas motoras e fonéticas após acidente vascular cerebral (AVC) e não se julgar em condições de participar; 1 por ser portador de HIV.

Dos 71 pacientes não-cardiopatas elegíveis, 62 (87,3\%) puderam ser incluídos na pesquisa e ter as condições periodontais investigadas. Esta amostra corresponde a 40,2\% do grupo total de pacientes examinados inicialmente (154). Os 9 pacientes excluídos da investigação periodontal o foram por apresentar um dos fatores de exclusão: 2 por não quererem participar; 4 por não disporem de tempo; 1 por ser presidiário e não haver adequadas condições de segurança para seu deslocamento e exame bucal; 2 por serem portadores de HIV.

Entre os pacientes cardiopatas observa-se que 48 (82,8\%) são homens e 10 $(17,2 \%)$ são mulheres. Neste grupo as idades variaram de 33 a 75 anos nos homens, e de 38 a 70 anos nas mulheres. A mediana de idade foi 53 anos nos homens e 55 nas mulheres. A média de idade foi 53 anos em ambos os sexos. Observou-se 52 pacientes (89,6\%) entre 40 e 69 anos, sendo 18 (31,0\%) de 40 a 49 anos, $18(31,0 \%)$ de 50 a 59 anos, e $16(27,6 \%)$ de 60 a 69 anos.

Entre os pacientes não-cardiopatas observa-se que 46 (74,2\%) são homens e $16(25,8 \%)$ são mulheres. Neste grupo as idades variaram de 30 a 61 anos nos homens, e de 30 a 60 anos nas mulheres. A mediana de idade foi de 39 anos em homens e 35 em mulheres. A média de idade foi de 40 anos em homens e 37 em mulheres. Observa-se que 35 pacientes $(56,4 \%)$ têm de 30 a 39 anos, $20(32,3 \%)$ têm de 40 a 49 anos, e $7(11,3 \%)$ têm de 50 a 64 anos; 55 pacientes $(88,7 \%)$ têm menos de 50 anos; 49 pacientes $(79,0 \%)$ abaixo de 45 anos; $56,5 \%$ abaixo de 40 anos. 
A tabela 4 ilustra a composição do grupo segundo grupo etário e sexo, em ambos os grupos estudados.

Tabela 4 - Distribuição de pacientes cardiopatas e não-cardiopatas submetidos à investigação periodontal, segundo sexo e idade. HCFMRP-USP, 2002

\begin{tabular}{c|cccccccc|cc}
\hline & \multicolumn{7}{|c}{ CARDIOPATAS } & \multicolumn{2}{c}{ NÃO-CARDIOPATAS } & \multirow{2}{*}{ Total } \\
$\begin{array}{c}\text { Grupo } \\
\text { etário }\end{array}$ & $\mathrm{n}$ & $\%$ & $\mathrm{n}$ & $\%$ & $\mathrm{n}$ & $\%$ & $\mathrm{n}$ & $\%$ & $\mathrm{n}$ & $\%$ \\
\hline $30-34$ & 1 & 2,1 & - & - & 12 & 26,1 & 8 & 50,0 & 21 & 17,5 \\
$35-39$ & 2 & 4,2 & 1 & 10,0 & 12 & 26,1 & 3 & 18,8 & 18 & 15,0 \\
$40-44$ & 9 & 18,7 & 2 & 20,2 & 12 & 26,1 & 2 & 12,5 & 25 & 20,8 \\
$45-49$ & 6 & 12,5 & 1 & 10,0 & 4 & 8,7 & 2 & 12,5 & 13 & 10,8 \\
$50-54$ & 9 & 18,7 & 1 & 10,0 & 3 & 6,5 & - & - & 13 & 10,8 \\
$55-59$ & 6 & 12,5 & 2 & 20,0 & 1 & 2,2 & - & - & 9 & 7,5 \\
$60-64$ & 9 & 18,7 & 1 & 10,0 & 2 & 4,3 & 1 & 6,2 & 13 & 10,8 \\
$65-69$ & 5 & 10,4 & 1 & 10,0 & - & - & - & - & 6 & 5,0 \\
$70-74$ & - & - & 1 & 10,0 & - & - & - & - & 1 & 0,8 \\
75 e + & 1 & 2,1 & - & - & - & - & - & - & 1 & 0,8 \\
\hline Total & 48 & 100,0 & 10 & 100,0 & 46 & 100,0 & 16 & 100,0 & 120 & 100,0 \\
\hline
\end{tabular}

Embora não apresentados em tabelas, os resultados permitiram classificar as pessoas segundo:

- $\quad$ procedência: observou-se que 29 pacientes cardiopatas (50,0\%) são procedentes de Ribeirão Preto-SP, 13 (22,4\%) dos demais municípios da DIR XVIII, $9(15,5 \%)$ de outros municípios do Estado de São Paulo, 6 (10,4\%) do Estado de 
Minas Gerais, e $1(1,7 \%)$ do Estado de Alagoas. Entre os pacientes não-cardiopatas, 31 (50,0\%) são procedentes de Ribeirão Preto-SP, 12 (19,4\%) dos demais municípios da DIR XVIII, 11 (17,7\%) de outros municípios do Estado de São Paulo, e 8 (12,9\%) do Estado de Minas Gerais.

escolaridade: observou-se que 4 pacientes cardiopatas $(6,9 \%)$ não estudaram, $25(43,1 \%)$ têm $1^{\circ}$ grau incompleto, $6(10,3 \%)$ têm $1^{\circ}$ grau completo, 3 $(5,2 \%)$ têm $2^{\circ}$ grau incompleto, $9(15,5 \%)$ têm $2^{\circ}$ grau completo, $2(3,5 \%)$ têm o superior incompleto, e $9(15,5 \%)$ têm curso superior completo. Entre os pacientes não-cardiopatas, $1(1,6 \%)$ não estudou, $13(21,0 \%)$ têm $1^{\circ}$ grau incompleto, 9 $(14,5 \%)$ têm $1^{\circ}$ grau completo, $3(4,8 \%)$ têm $2^{\circ}$ grau incompleto, $17(27,4 \%)$ têm $2^{\circ}$ grau completo, $6(9,7 \%)$ têm superior incompleto, e $13(21,0 \%)$ têm superior completo.

hábito de fumar: observou-se que $6(10,4 \%)$ dos pacientes cardiopatas são fumantes, $34(58,6 \%)$ são ex-fumantes, e $18(31,0 \%)$ referiram nunca ter praticado o tabagismo. Entre os pacientes não-cardiopatas, 21 (33,9\%) são fumantes, $14(22,6 \%)$ são ex-fumantes, e $27(43,5 \%)$ referiram nunca ter praticado o tabagismo.

Segundo o consumo de álcool, a amostra foi classificada em "consome todos os dias" a "nunca consumiu", passando por categorias que quantificam os dias de consumo de álcool e a condição de ex-consumidor. Observou-se que 26 pacientes cardiopatas $(44,8 \%)$ podem ser incluídos na condição de consumidor e $32(55,2 \%)$ como não-consumidor. Entre os pacientes não-cardiopatas, 15 pacientes $(24,2 \%)$ podem ser incluídos na condição de consumidor e $47(75,8 \%)$ como nãoconsumidor.Os resultados encontram-se na tabela 5. 
Tabela 5 - Distribuição de pacientes cardiopatas e não-cardiopatas submetidos à investigação periodontal, segundo o consumo de álcool. HCFMRP-USP, 2002.

\begin{tabular}{l|cccc}
\hline \multicolumn{1}{c|}{ Consumo de álcool } & \multicolumn{3}{c}{ CARDIOPATAS } & \multicolumn{2}{c}{ NÃO-CARDIOPATAS } \\
& $\mathrm{n}$ & $\%$ & $\mathrm{n}$ & $\%$ \\
\hline Nunca consumiu & 13 & 22,4 & 14 & 22,6 \\
Ex-consumidor & 19 & 32,8 & 33 & 53,2 \\
Consome todos os dias & 3 & 5,2 & 1 & 1,6 \\
Consome de 5 - 6 dias por semana & - & - & 1 & 1,6 \\
Consome de 3 - 4 dias por semana & 3 & 5,2 & 4 & 6,5 \\
Consome de 1 - 2 dias por semana & 8 & 13,8 & 3 & 4,8 \\
Consome de 3 - 4 dias ao mês & 2 & 3,4 & 3 & 4,8 \\
Consome de 1 - 2 dias ao mês & 6 & 10,3 & 3 & 4,8 \\
Consome menos de 1 dia ao mês & 4 & 6,9 & - & - \\
\hline \multicolumn{1}{c}{ Total } & 58 & 100,0 & 62 & 100,0 \\
\hline \multicolumn{5}{c}{}
\end{tabular}

Mesmo não apresentados em tabelas, os resultados permitiram classificar as pessoas segundo:

- $\quad$ presença de doenças de interesse à periodontia: observou-se que 33 pacientes cardiopatas $(56,9 \%)$ relataram portar doença de interesse à periodontia, e $25(43,1 \%)$ não. Ainda segundo esta variável, a amostra foi também estratificada quanto ao tipo de doença. Um mesmo paciente pode apresentar uma ou mais das doenças classificadas. Observou-se que dos 33 pacientes que relatam doenças de interesse à periodontia, $17(29,3 \%)$ têm diabetes, 2 (3,4\%) tiveram AVC, e 20 $(34,5 \%)$ têm hipertensão arterial. Entre os pacientes não-cardiopatas, um percentual significativamente menor do que no grupo de pacientes cardiopatas $(9,7 \%$ ou 6 pacientes) relata alguma doença de interesse à periodontia. Dos 6 pacientes que relatam doenças de interesse à periodontia, $1(1,6 \%)$ tem diabetes e $5(8,1 \%)$ têm hipertensão arterial.

- $\quad$ uso contínuo de medicação: observou-se que 58 (100\%) dos pacientes cardiopatas fazem uso contínuo de medicação. Ainda segundo esta variável, amostra foi também estratificada quanto ao tipo de medicamento de uso contínuo que pode influenciar a saúde periodontal. Um mesmo paciente pode participar em uma ou mais das categorias de medicamentos. Observou-se que $5(8,6 \%)$ fazem uso de anticoagulante, $56(96,6 \%)$ de antiagregante plaquetário, e $58(100,0 \%)$ de outros 
medicamentos. Percentual significativamente menor de pacientes não-cardiopatas (9,7\% ou 6 pessoas) faz uso de medicamentos de uso contínuo, excluídos os medicamentos utilizados no tratamento das hepatites. Observou-se que $2(3,2 \%)$ usam antiagregante plaquetário, e $6(9,7 \%)$ outro medicamento.

Segundo a variável conhecimento prévio sobre a existência de doenças periodontais, observou-se que $13,8 \%$ dos pacientes cardiopatas desconhecem, $60,3 \%$ conhecem porque o próprio paciente ou alguém conhecido tem, e 25,9\% receberam orientações de profissionais, ou através de leitura. Entre os pacientes nãocardiopatas, observou-se que 12,9\% desconhece, 53,2\% conhece porque o próprio paciente ou alguém conhecido tem, e 32,3\% recebeu orientações profissionais ou através de leitura; 1 paciente $(1,6 \%)$ tem formação na área de periodontia. Os resultados encontram-se na tabela 6 .

Tabela 6 - Distribuição de pacientes cardiopatas e não-cardiopatas submetidos à investigação periodontal, segundo o conhecimento prévio sobre a existência de doenças periodontais. HCFMRP-USP, 2002.

\begin{tabular}{l|rrrrr}
\hline & \multicolumn{3}{|c}{ CARDIOPATAS } & \multicolumn{2}{c}{ NÃO-CARDIOPATAS } \\
Conhecimento sobre Doença Periodontal & $\mathrm{n}$ & \multicolumn{1}{c}{$\%$} & $\mathrm{n}$ & \multicolumn{1}{c}{$\%$} \\
\hline Não sabe que existem & 8 & 13,8 & 8 & 12,9 \\
Alguém da família ou amigo tem & 27 & 46,5 & 27 & 43,5 \\
Recebeu orientações de profissionais & 12 & 20,7 & 15 & 24,2 \\
Leu a respeito & 3 & 5,2 & 5 & 8,1 \\
Acha que tem este tipo de doença & 8 & 13,8 & 6 & 9,7 \\
Outra fonte & - & - & 1 & 1,6 \\
\hline \multicolumn{1}{c|}{ Total } & 58 & 100,0 & 62 & 100,0 \\
\hline
\end{tabular}

Embora não apresentados em tabelas, os resultados permitiram classificar segundo as seguintes variáveis:

- $\quad$ orientações sobre métodos e dispositivos de higiene bucal: observou-se que 38 pacientes cardiopatas $(65,5 \%)$ admitem ter recebido orientações, contra 20 $(34,5 \%)$ que não receberam. Para tentar-se identificar a origem da orientação recebida, a amostra foi também classificada nos estratos "dentista", "família", 
"escola ou outra instituição" e "leitura". Um mesmo paciente pode ter citado mais de uma fonte de informações. Observou-se que 27 (71,1\%) relataram como fonte de informações o cirurgião-dentista, $3(7,9 \%)$ a família, 7 (18,4\%) a escola ou outra instituição, e $6(15,8 \%)$ a leitura. Entre os pacientes não-cardiopatas, $42(67,7 \%)$ admitem ter recebido orientações, contra 20 (32,3\%) que não. Observou-se que 37 $(88,1 \%)$ relataram como fonte de informações o cirurgião-dentista, $1(2,4 \%)$ a família, $6(14,3 \%)$ a escola ou outra instituição, e $3(7,1 \%)$ a leitura.

- hábito diário de escovação: observou-se que 56 pacientes cardiopatas (96,5\%) têm o hábito de escovar diariamente os dentes, e 2 (3,5\%) não. Ainda segundo esta variável, a amostra foi estratificada segundo o número de escovações. Observou-se que 7 pessoas (12,1\%) escovam 1 vez ao dia, 20 (34,5\%) 2 vezes ao dia, $23(39,6 \%) 3$ vezes ao dia, e $8(13,8 \%) 4$ ou mais vezes ao dia. Entre os pacientes não-cardiopatas, $60(96,8 \%)$ têm o hábito de escovar diariamente os dentes, e 2 $(3,2 \%)$ não. Observou-se que 5 pacientes $(8,1 \%)$ escovam 1 vez ao dia, $13(21,0 \%) 2$ vezes ao dia, $24(38,7 \%) 3$ vezes ao dia, e $20(32,2 \%) 4$ vezes ou mais vezes ao dia.

- tempo de escovação: observou-se que 50 pessoas $(86,2 \%)$ declaram escovar em 1 a 3 minutos, $7(12,1 \%)$ em 4 a 9 minutos, e 1 (1,7\%) em 4 minutos ou mais, segundo o tempo aproximado destinado à escovação que o paciente considera a mais importante ou aquela em que mais capricha na higiene dos dentes. Entre os pacientes não-cardiopatas, 48 (77,4\%) declaram escovar em 1 a 3 minutos, 13 (21,0\%) em 4 a 9 minutos, e $1(1,6 \%)$ em 10 minutos ou mais, também segundo o tempo aproximado destinado à escovação que o paciente considera a mais importante ou aquela em que mais capricha na higiene dos dentes.

- $\quad$ tipo de escova: observou-se que 9 pacientes cardiopatas $(15,5 \%)$ utilizam escova dura, $25(43,1 \%)$ escova média, e $24(41,4 \%)$ escova macia. Entre os pacientes não-cardiopatas, 8 (12,9\%) utilizam escova dura, 25 (40,3\%) escova média, e $29(46,8 \%)$ escova macia.

- tempo aproximado entre as trocas da escova dental: a amostra foi estratificada segundo o tempo em meses e anos, para os participantes que recordassem o tempo aproximado para troca. Dos 28 pacientes cardiopatas que 
recordaram o tempo entre a troca da escova, $1(3,6 \%)$ troca com intervalo de 1 mês, $13(46,4 \%)$ de 2 meses, $5(17,9 \%)$ de 3 meses, 1 (3,6\%) de 4 meses, 4 (14,3\%) de 6 meses, $3(10,7 \%)$ de 1 ano, e $1(3,6 \%)$ de 2 anos. Ainda segundo esta variável, a amostra foi classificada segundo os critérios "aspecto", "perda" e "quebra", quando os participantes não recordassem o tempo de troca. Dos 30 pacientes cardiopatas que não recordaram o tempo, $28(93,3 \%)$ trocam pelo aspecto, e $2(6,7 \%)$ quando quebram a escova. Entre os pacientes não-cardiopatas, dos 27 que recordaram o tempo, 5 (18,5\%) trocam com intervalo de 1 mês, 9 (33,3\%) de 2 meses, 4 (14,8\%) de 3 meses, 6 (22,2\%) de 4 meses, $1(3,7 \%)$ de 6 meses, e $2(7,4 \%)$ de 1 ano. Dos 35 pacientes que não recordaram o tempo, o "aspecto" representou 100,0\% do critério de troca.

- $\quad$ uso individual ou coletivo/familiar da escova dental: observou-se que os $58(100,0 \%)$ pacientes cardiopatas fazem uso individual da escova dental. Entre os pacientes não-cardiopatas, $62(100,0 \%)$ fazem uso individual da escova dental.

- $\quad$ uso de fio/fita dental: observou-se que 23 pacientes cardiopatas $(39,7 \%)$ não usam, $16(27,6 \%)$ usam às vezes e 19 (32,7\%) usam diariamente. Entre os pacientes não-cardiopatas, $13(21,0 \%)$ não usam, 26 (41,9\%) usam às vezes e 23 $(37,1 \%)$ usam diariamente.

- $\quad$ tipo de creme dental: observou-se que os 58 pacientes cardiopatas (100\%) usam creme dental. Destes, 55 (94,8\%) usam creme dental comum, $1(1,7 \%)$ usa variados tipos, e $2(3,5 \%)$ usam creme dental com componente medicamentoso. Entre os pacientes não-cardiopatas, $62(100,0 \%)$ usam creme dental. Destes, 50 $(80,7 \%)$ usam creme dental comum, $11(17,7 \%)$ usam variados tipos, e $1(1,6 \%)$ usa creme dental com componente medicamentoso.

- uso de enxagüatório bucal: observou-se que 5 pacientes cardiopatas $(8,6 \%)$ usam diariamente, $5(8,6 \%)$ usam às vezes, e $48(82,8 \%)$ não usam enxaguiatório. Ainda segundo esta variável, a amostra foi estratificada em “clorexedina", "listerine”, "triclosan”, “cetilperidínio", "própolis”, “água oxigenada", "solução fluoretada", "solução caseira" e "outro". Dos 10 pacientes cardiopatas que relataram fazer uso de enxagüatório bucal 4 (40,0\%) usam cetilperidínio, e 6 (60,0\%) 
usam listerine. Entre os pacientes nã0-cardiopatas, 6 (9,7\%) usam diariamente, 5 $(8,1 \%)$ usam às vezes e $51(82,2 \%)$ não usam enxagüatório. Dos 11 pacientes nãocardiopatas que relataram fazer uso de enxagüatório bucal, $4(30,8 \%)$ usam cetilperidínio, $8(61,5 \%)$ usam listerine e $1(7,7 \%)$ usa triclosan.

- $\quad$ uso e tipo de acessório de higiene bucal: a amostra foi classificada em "sim" e "não", e também em "palito" e "outros acessórios" (escova interproximal, escova bitufo, waterpik, massageadores gengivais, limpador de língua). Observou-se que 32 pacientes $(55,2 \%)$ usam algum acessório. Desses, $100 \%$ refere uso exclusivo de palito dental. Entre os pacientes não-cardiopatas, $30(48,4 \%)$ usam algum acessório. Desses, 100,0\% refere uso exclusivo de palito dental.

- $\quad$ segundo a variável Terapia Periodontal Básica, observou-se que 15 $(25,9 \%)$ dos pacientes cardiopatas relatam não ter feito raspagem dentária, 37 $(63,8 \%)$ fazem eventualmente, e apenas $6(10,3 \%)$ fazem rotineiramente. Entre os pacientes não-cardiopatas, 15 (24,2\%) relatam não ter feito raspagem dentária, 29 $(46,8 \%)$ fazem eventualmente e $18(29,0 \%)$ fazem rotineiramente.

- $\quad$ segundo a variável Terapia Periodontal Complexa/Cirúrgica, a amostra foi classificada em "nunca fez/nunca indicada", "indicada e não realizada" e "realizada conforme indicação". Observa-se que $54(93,1 \%)$ dos pacientes cardiopatas relatam nunca ter feito ou nunca ter sido indicada terapia complementar cirúrgica e $4(6,9 \%)$ tê-la feito conforme indicação. Entre os pacientes nãocardiopatas, $58(93,6 \%)$ relatam nunca ter feito ou nunca ter sido indicada terapia complementar cirúrgica, 2 (3,2\%) relatam que foi indicada e não realizada e 2 (3,2\%) tê-la feito conforme indicação.

- $\quad$ segundo a variável Terapia Periodontal de Manutenção, a amostra foi classificada em "não faz", "indicada e não realizada" e "realizada conforme indicação". Observa-se que 15 pacientes cardiopatas (25,9\%) não fazem, 37 (63,8\%) relatam que foi indicada e não realizada e apenas $6(10,3 \%)$ a realiza. Entre os pacientes não-cardiopatas, $15(24,2 \%)$ não fazem, 29 (46,8\%) relatam que foi indicada e não realizada e $18(29,0 \%)$ a realizam. 
- $\quad$ segundo a variável queixas referidas, observou-se sua presença e o tipo de queixa. Um mesmo participante pode ter mencionado uma ou mais queixas. Observou-se que 49 pacientes cardiopatas $(84,5 \%)$ referiram queixas bucais, com as seguintes frequiências: $26(53,1 \%)$ se relatam cárie dentária, $20(40,8 \%)$ doença periodontal, $19(38,8 \%)$ sensibilidade, $16(32,6 \%)$ ausência de dentes naturais, 13 (26,5\%) hábito parafuncional, 13 (26,5\%) estética, 10 (20,4\%) maloclusão, 8 $(16,3 \%)$ dor, $7(14,3 \%)$ lesões de tecidos moles, $4(8,2 \%)$ do uso de prótese, $1(2,0 \%)$ fonética e $1(2,0 \%)$ outra queixa. Entre os pacientes não-cardiopatas observou-se 39 $(62,9 \%)$ com queixas bucais e $23(37,1 \%)$ não, com as seguintes frequiências: 17 (43,6\%) com doença periodontal, 13 (33,3\%) maloclusão, 12 (30,8\%) ausência de dentes naturais, $10(25,6 \%)$ cárie, $9(23,1 \%)$ sensibilidade, $8(20,5 \%)$ hábito parafuncional, $7(18,0 \%)$ estética, $4(10,3 \%)$ do uso de prótese, $3(7,7 \%)$ fonética, 2 $(5,1 \%)$ dor e $1(2,6 \%)$ lesões de tecidos moles.

Segundo a variável necessidades observadas, observou-se que 58 (100\%) pacientes cardiopatas apresentaram alguma necessidade após o exame bucal. Ainda segundo esta variável, a amostra foi classificada segundo a área de necessidade. Um mesmo paciente pode ter necessidades em mais de uma das áreas. Observou-se que $100,0 \%$ dos pacientes cardiopatas necessitam de tratamento periodontal, 70,7\% de tratamento restaurador, $62,1 \%$ de orientações quanto a exames rotineiros para prevenção de câncer bucal, 41,4\% de reabilitação protética, 20,7\% de cirurgia para remoção de elementos dentais condenados, 3,4\% de endodontia, 3,4\% tem outra necessidade (ortodontia etc.). Entre os pacientes não-cardiopatas, observou-se que 51 $(82,3 \%)$ apresentam alguma necessidade após o exame bucal, e 11 (17,7\%) não, sendo que $82,3 \%$ dos pacientes necessitam de tratamento periodontal, 21,0\% de tratamento restaurador, $17,7 \%$ de reabilitação protética, $14,5 \%$ de cirurgia para remoção de elementos dentais condenados (neste grupo este componente foi representado maciçamente por terceiros molares), 9,7\% orientações quanto a exames rotineiros para prevenção de câncer bucal e 6,5\% têm outras necessidades (ortodontia etc.). Os resultados são apresentados na tabela 7. 
Tabela 7 - Distribuição de pacientes cardiopatas e não-cardiopatas submetidos à investigação periodontal, segundo a área de necessidade. HCFMRP-USP, 2002.

\begin{tabular}{|c|c|c|c|c|}
\hline \multirow[b]{2}{*}{ Área } & \multicolumn{2}{|c|}{ CARDIOPATAS } & \multicolumn{2}{|c|}{ NÃO-CARDIOPATAS } \\
\hline & $\mathrm{n}$ & $\%$ & $\mathrm{n}$ & $\%$ \\
\hline Prótese & 24 & 41,4 & 11 & 17,7 \\
\hline Periodontia & 58 & 100,0 & 51 & 82,3 \\
\hline Endodontia & 2 & 3,4 & - & - \\
\hline Cirurgia/exodontia & 12 & 20,7 & 9 & 14,5 \\
\hline $\begin{array}{l}\text { Orientações para prevenção de } \\
\text { câncer bucal }\end{array}$ & 36 & 62,1 & 6 & 9,7 \\
\hline Dentística & 41 & 70,7 & 13 & 21,0 \\
\hline Outra(s) necessidade(s) & 2 & 3,4 & 4 & 6,5 \\
\hline Sem necessidades & - & - & 11 & 17,7 \\
\hline Número de pacientes & 58 & 100,0 & 62 & 100,0 \\
\hline
\end{tabular}

A tabela 8 ilustra a variável necessidades observadas, categorizada segundo a escolaridade. Observa-se que 50\% dos pacientes cardiopatas com necessidades bucais, não estudou ou têm o $1^{\circ}$ grau incompleto. Entre os pacientes não-cardiopatas observa-se que $27,5 \%$ dos pacientes com necessidades, não estudou ou têm o $1^{\circ}$ grau incompleto. Observa-se que quanto maior a escolaridade, mais isentos de necessidades estão os pacientes não-cardiopatas.

Tabela 8 - Distribuição de pacientes cardiopatas e não-cardiopatas submetidos à investigação periodontal, segundo a presença de necessidades bucais e a escolaridade. HCFMRP-USP, 2002.

\begin{tabular}{l|rrrrrrrr}
\multicolumn{1}{r}{ Grupo } & \multicolumn{4}{c}{ CARDIOPATAS } & \multicolumn{3}{c}{ NÃO-CARDIOPATAS } \\
\cline { 2 - 10 } Escolaridade & \multicolumn{2}{|c}{ Sim } & \multicolumn{2}{c}{ Não } & \multicolumn{2}{c}{ Sim } & \multicolumn{2}{c}{ Não } \\
\hline Nunca estudou & 4 & 6,9 & - & - & 1 & 1,9 & - & - \\
$1^{\circ}$ grau incompleto & 25 & 43,1 & - & - & 13 & 25,5 & - & - \\
$1^{\circ}$ grau completo & 6 & 10,3 & - & - & 7 & 13,7 & 2 & 18,1 \\
$2^{\text {o }}$ grau incompleto & 3 & 5,2 & - & - & 3 & 5,9 & - & - \\
$2^{\text {o }}$ grau completo & 9 & 15,5 & - & - & 13 & 25,5 & 4 & 36,4 \\
Superior incompleto & 2 & 3,5 & - & - & 5 & 9,8 & 1 & 9,1 \\
Superior completo & 9 & 15,5 & - & - & 9 & 17,6 & 4 & 36,4 \\
\hline \multicolumn{1}{c}{ Total } & 58 & 100,0 & - & - & 51 & 100,0 & 11 & 100,0 \\
\hline
\end{tabular}


A tabela 9 ilustra a variável necessidade observada de tratamento periodontal, segundo as categorias "nenhuma", "raspagem de cálculo", "tratamento em bolsa periodontal de $4-5 \mathrm{~mm}$ " e "tratamento em bolsa periodontal $\geq 6 \mathrm{~mm}$ ". Observou-se que 79,3\% dos pacientes cardiopatas têm necessidade de tratamento de bolsas periodontais $\geq 6 \mathrm{~mm}, 15,5 \%$ de tratamento de bolsas periodontais de 4 a $5 \mathrm{~mm}$, e apenas $5,2 \%$ necessitam de raspagem de cálculo em sítios com profundidade de sondagem até $3 \mathrm{~mm}$; que $3(5,2 \%)$ dos participantes deste grupo necessitam de tratamento periodontal de complexidade reduzida, onde a profundidade de sondagem é $\leq 3 \mathrm{~mm}$; que $55(94,8 \%)$ necessitam de tratamento periodontal de maior complexidade, com profundidade de sondagem de $4 \mathrm{~mm}$ e mais. Entre os pacientes não-cardiopatas $9,7 \%$ têm necessidade de tratamento periodontal em bolsa $\geq 6 \mathrm{~mm}$, 24,2\% necessitam de tratamento periodontal em bolsa de 4 a $5 \mathrm{~mm}, 48,4 \%$ dos pacientes tem necessidade de raspagem de cálculo em sítios com profundidade de sondagem até $3 \mathrm{~mm}$, e 17,7\% nada necessitam; que $30(48,4 \%)$ dos participantes deste grupo necessitam de tratamento periodontal de complexidade reduzida, onde a profundidade de sondagem é $\leq 3 \mathrm{~mm}$; que $21 \quad(33,9 \%)$ necessitam de tratamento periodontal de maior complexidade, com profundidade de sondagem de $4 \mathrm{~mm}$ e mais.

Tabela 9 - Distribuição de pacientes cardiopatas e não-cardiopatas submetidos à investigação periodontal, segundo a necessidade observada de tratamento periodontal. HCFMRP-USP, 2002.

\begin{tabular}{c|rrrr}
\hline Necessidade de & \multicolumn{3}{|c}{ CARDIOPATAS } & \multicolumn{2}{c}{ NÃO-CARDIOPATAS } \\
tratamento periodontal & $\mathrm{n}$ & \multicolumn{1}{c}{$\%$} & $\mathrm{n}$ & \multicolumn{1}{c}{$\%$} \\
\hline Nenhuma necessidade & - & - & 11 & 17,7 \\
Raspagem de cálculo dental & 3 & 5,2 & 30 & 48,4 \\
Tratamento bolsa 4 a 5mm & 9 & 15,5 & 15 & 24,2 \\
Tratamento bolsa $\geq 6 \mathrm{~mm}$ & 46 & 79,3 & 6 & 9,7 \\
\hline Número de pacientes & 58 & 100,0 & 62 & 100,0 \\
\hline
\end{tabular}


Conforme demonstrado na tabela 10, quanto à necessidade observada de tratamento periodontal segundo o tempo de higiene, observou-se que das 58 pacientes cardiopatas que têm alguma necessidade periodontal, 55 (94,8\%) têm grau máximo de necessidade (bolsas $4-5 \mathrm{~mm}$ e $\geq 6 \mathrm{~mm}$ ) e $48(87,3 \%)$ escovam de 1 a 3 minutos. Considerou-se como tendo grau máximo de necessidade periodontal os pacientes portadores de bolsas periodontais de $4-5 \mathrm{~mm}$ e $\geq 6 \mathrm{~mm}$, frequentemente não diagnosticadas e tratadas pelos profissionais clínicos gerais e outras especialidades odontológicas exceto a periodontia.

Tabela 10 - Distribuição de pacientes cardiopatas submetidos à investigação periodontal, segundo o tempo de escovação agrupado e grau máximo de necessidade periodontal. HCFMRP-USP, 2002.

\begin{tabular}{|c|c|c|}
\hline \multirow[b]{2}{*}{ Tempo de escovação agrupado } & \multicolumn{2}{|c|}{ Grau máximo de necessidade } \\
\hline & $\mathrm{n}$ & $\%$ \\
\hline 1 a 3 minutos & 48 & 87,3 \\
\hline 4 a 9 minutos & 6 & 10,9 \\
\hline 10 e mais & 1 & 1,8 \\
\hline Total & 55 & 100,0 \\
\hline
\end{tabular}

Observou-se que de 58 pacientes cardiopatas, 50 usam tempo de escovação de 1 a 3 minutos, dos quais $48(96,0 \%)$ têm grau máximo de necessidade periodontal; 7 pacientes usam tempo de 4 minutos e mais, das quais $6(85,7 \%)$ também têm grau máximo de necessidade periodontal; 1 paciente $(100,0 \%)$ que escova 10 minutos ou mais também se apresenta no grau máximo de necessidade. Observou-se que 87,3\% dos pacientes com grau máximo de necessidade periodontal praticam a escovação dentária com tempo médio de 1 a 3 minutos.

Ainda quanto à necessidade observada de tratamento periodontal segundo o tempo de higiene, observou-se que de 51 pacientes não-cardiopatas que têm alguma necessidade, 42 usam tempo de 1 a 3 minutos; destes, 24 (57,1\%) têm grau mínimo de necessidade e $18(42,8 \%)$ têm grau máximo de necessidade na área de periodontia. Dos 9 que usam tempo de 4 minutos e mais, $6(66,7 \%)$ têm grau mínimo de necessidade e $3(33,3 \%)$ têm grau máximo de necessidade periodontal. 
Na tabela 11 observa-se que $30(58,8 \%)$ pacientes não-cardiopatas necessitam de tratamento periodontal de complexidade reduzida, onde a profundidade de sondagem é $\leq 3 \mathrm{~mm}$; em contrapartida 21 (41,2\%) necessitam de tratamento periodontal de maior complexidade, com profundidade de sondagem de $4 \mathrm{~mm}$ e mais.

Tabela 11 - Distribuição de pacientes não-cardiopatas submetidos à investigação periodontal, segundo o tempo de escovação agrupado e grau mínimo de necessidade periodontal. HCFMRP-USP, 2002.

\begin{tabular}{c|cc}
\hline & \multicolumn{2}{|c}{ Grau mínimo de necessidade } \\
Tempo de escovação agrupado & $\mathrm{n}$ & $\%$ \\
\hline 1 a 3 minutos & 24 & 57,1 \\
4 a 9 minutos & 5 & 62,5 \\
10 e mais & 1 & 100,0 \\
\hline Total & 30 & 100,0 \\
\hline
\end{tabular}

A tabela 12 mostra a necessidade observada de tratamento periodontal, classificando-a nas categorias "nenhuma ou grau mínimo" e "grau máximo de necessidade", segundo a presença de tabagismo. Entre os pacientes cardiopatas observa-se que $40(100 \%)$ dos fumantes e ex-fumantes têm grau máximo de necessidade em periodontia; em contrapartida, dos que nunca fumaram, $3(16,7 \%)$ necessitam de tratamento menos complexo e $17(83,3 \%)$ têm grau máximo de necessidade em periodontia. Entre os pacientes não-cardiopatas observa-se que $33,3 \%$ dos fumantes e 42,9\% dos ex-fumantes têm grau máximo de necessidade de tratamento periodontal; em contrapartida dos que nunca fumaram, $19(70,4 \%)$ necessitam de tratamento menos complexo e 8 (29,6\%) têm grau máximo de necessidade. 
Tabela 12 - Distribuição de pacientes cardiopatas e não-cardiopatas submetidos à investigação periodontal, segundo a necessidade observada de tratamento periodontal por pessoa e o hábito de tabagismo. HCFMRP-USP, 2002.

\begin{tabular}{|c|c|c|c|c|c|c|c|c|}
\hline \multirow{3}{*}{$\begin{array}{l}\text { Necessidade de } \\
\text { tratamento } \\
\text { periodontal }\end{array}$} & \multicolumn{4}{|c|}{ CARDIOPATAS } & \multicolumn{4}{|c|}{ NÃO-CARDIOPATAS } \\
\hline & \multicolumn{2}{|c|}{$\begin{array}{l}\text { Nenhuma ou } \\
\text { grau mínimo }\end{array}$} & \multicolumn{2}{|c|}{$\begin{array}{c}\text { Grau } \\
\text { máximo }\end{array}$} & \multicolumn{2}{|c|}{$\begin{array}{l}\text { Nenhuma ou } \\
\text { grau mínimo }\end{array}$} & \multicolumn{2}{|c|}{$\begin{array}{c}\text { Grau } \\
\text { máximo }\end{array}$} \\
\hline & $\mathrm{n}$ & $\%$ & $\mathrm{n}$ & $\%$ & $\mathrm{n}$ & $\%$ & $\mathrm{n}$ & $\%$ \\
\hline Nunca fumou & 3 & 16,7 & 15 & 83,3 & 19 & 70,4 & 8 & 29,6 \\
\hline Ex-fumante & - & - & 34 & 100,0 & 8 & 57,1 & 6 & 42,9 \\
\hline Fumante & - & - & 6 & 100,0 & 14 & 66,7 & 7 & 33,3 \\
\hline Número de pacientes & 3 & 5,2 & 55 & 94,8 & 41 & 66,1 & 21 & 33,9 \\
\hline
\end{tabular}

Classificou-se a amostra segundo a necessidade de tratamento periodontal por indivíduo, para os diversos grupos etários. No grupo de 58 pacientes cardiopatas dos distintos grupos etários, cujos resultados são apresentados na tabela 13, observa-se que apresentam grau máximo de necessidade de tratamento periodontal (quando portadores de bolsas periodontais $\geq 6 \mathrm{~mm}$ ) o único representante do grupo etário $30 \mathrm{a}$ 34 anos (100,0\%), 100,0\% dos 3 pacientes do grupo etário 35 a 39 anos, 90,9\% dos 11 pacientes do grupo etário 40 a 44 anos, 71,4\% dos 7 pacientes do grupo etário 45 a 49 anos, 70,0\% dos 10 pacientes do grupo etário 50 a 54 anos, 100,0\% dos 8 pacientes do grupo etário 55 a 59 anos, 70,0\% dos 10 pacientes do grupo etário 60 a 64 anos, 50,0\% dos 6 pacientes do grupo etário 65 a 69 anos, 100,0\% dos 2 pacientes dos grupos etários 70 a 74 anos e 75 a 79 anos. Ausência de necessidade de tratamento periodontal não foi observada em nenhum paciente deste grupo. 
Tabela 13 - Distribuição dos achados da necessidade de tratamento periodontal em pacientes cardiopatas submetidos à investigação periodontal, segundo grupo etário. HCFMRP-USP, 2002.

\begin{tabular}{|c|c|c|c|c|c|c|c|c|}
\hline \multirow{3}{*}{$\begin{array}{l}\text { Grupo } \\
\text { Etário }\end{array}$} & \multicolumn{6}{|c|}{ Necessidade de tratamento periodontal } & & \\
\hline & \multicolumn{2}{|c|}{2} & \multicolumn{2}{|c|}{3} & \multicolumn{2}{|c|}{4} & \multicolumn{2}{|c|}{ Total } \\
\hline & $\mathrm{n}$ & $\%$ & $\mathrm{n}$ & $\%$ & $\mathrm{n}$ & $\%$ & $\mathrm{n}$ & $\%$ \\
\hline $30-34$ & - & - & - & - & 1 & 100,0 & 1 & 100,0 \\
\hline $35-39$ & - & - & - & - & 3 & 100,0 & 3 & 100,0 \\
\hline $40-44$ & - & - & 1 & 9,1 & 10 & 90,9 & 11 & 100,0 \\
\hline $45-49$ & 1 & 14,3 & 1 & 14,3 & 5 & 71,4 & 7 & 100,0 \\
\hline $50-54$ & - & - & 3 & 30,0 & 7 & 70,0 & 10 & 100,0 \\
\hline $55-59$ & - & - & - & - & 8 & 100,0 & 8 & 100,0 \\
\hline $60-64$ & - & - & 3 & 30,0 & 7 & 70,0 & 10 & 100,0 \\
\hline $65-69$ & 2 & 33,3 & 1 & 16,7 & 3 & 50,0 & 6 & 100,0 \\
\hline $70-74$ & - & - & - & - & 1 & 100,0 & 1 & 100,0 \\
\hline $75-79$ & - & - & - & - & 1 & 100,0 & 1 & 100,0 \\
\hline Total & 3 & 5,2 & 9 & 15,5 & 46 & 79,3 & 58 & 100,0 \\
\hline
\end{tabular}

0=sem necessidade; $1=$ tratamento para remoção do biofilme dentário + instruções de higiene bucal $(\mathrm{IHB}) ; 2=$ remoção de cálculo $+\mathrm{IHB} ; 3=$ tratamento em bolsa periodontal entre 4 e $5 \mathrm{~mm}+\mathrm{IHB} ; 4=$ tratamento de bolsa periodontal $\geq 6 \mathrm{~mm}+\mathrm{IHB}$.

No grupo de 62 pacientes não-cardiopatas distribuídos nos distintos grupos etários, cujos resultados encontram-se na tabela 14, observa-se que apresentam grau máximo de necessidade de tratamento periodontal (quando portadores de bolsas periodontais $\geq 6 \mathrm{~mm}) 13,3 \%$ dos 15 pacientes do grupo etário 35 a 39 anos e 21,4\% dos 14 pacientes do grupo etário 40 a 44 anos. Nos demais grupos etários, não se observaram necessidades de tratamento periodontal em bolsas $\geq 6 \mathrm{~mm}$. Necessitaram de tratamento em bolsas periodontais moderadas ( 4 a $5 \mathrm{~mm}$ ) $25,0 \%$ dos 20 pacientes do grupo etário 30 a 34 anos, 20,0\% dos 15 pacientes do grupo etário 35 a 39 anos, 14,3\% dos 14 pacientes do grupo etário 40 a 44 anos, 33,3\% dos 3 pacientes do grupo etário 45 a 49 anos, 33,3\% dos 3 pacientes do grupo etário 50 a 54 anos, o único paciente $(100,0 \%)$ do grupo etário 55 a 59 anos, 33,3\% dos 3 pacientes do 
grupo etário 60 a 64 anos. Ausência de necessidade de tratamento periodontal foi observada em 17,7\% dos 62 pacientes deste grupo, sendo 10,0\% no grupo etário 30 a 34 anos, 20,0\% no grupo etário 35 a 39 anos, 28,6\% no grupo etário 40 a 44 anos, 16,7\% no grupo etário 45 a 49 anos e 33,3\% no grupo etário 60 a 64 anos. Resumindo-se esses achados, do total de 62 pacientes deste grupo, 17,7\% não apresentam necessidade de tratamento periodontal, 48,4\% necessitam de remoção de cálculo dentário, 24,2\% necessitam de tratamento em bolsas de 4 a $5 \mathrm{~mm}$ e 9,7\% necessitam de tratamento de bolsas $\geq 6 \mathrm{~mm}$.

Tabela 14 - Distribuição dos achados da necessidade de tratamento periodontal em pacientes não-cardiopatas submetidos à investigação periodontal, segundo grupo etário. HCFMRP-USP, 2002.

\begin{tabular}{|c|c|c|c|c|c|c|c|c|c|c|}
\hline \multirow{3}{*}{$\begin{array}{l}\text { Grupo } \\
\text { Etário }\end{array}$} & \multicolumn{8}{|c|}{ Necessidade de tratamento periodontal } & & \\
\hline & \multicolumn{2}{|c|}{0} & \multicolumn{2}{|c|}{2} & \multicolumn{2}{|c|}{3} & \multicolumn{2}{|c|}{4} & \multicolumn{2}{|c|}{ Total } \\
\hline & $\mathrm{n}$ & $\%$ & $\mathrm{n}$ & $\%$ & $\mathrm{n}$ & $\%$ & $\mathrm{n}$ & $\%$ & $\mathrm{n}$ & $\%$ \\
\hline $30-34$ & 2 & 10,0 & 13 & 65,0 & 5 & 25,0 & - & - & 20 & 100,0 \\
\hline $35-39$ & 3 & 20,0 & 7 & 46,7 & 3 & 20,0 & 2 & 13,3 & 15 & 100,0 \\
\hline $40-44$ & 4 & 28,6 & 5 & 35,7 & 2 & 14,3 & 3 & 21,4 & 14 & 100,0 \\
\hline $45-49$ & 1 & 16,7 & 3 & 50,0 & 2 & 33,3 & - & - & 6 & 100,0 \\
\hline $50-54$ & - & - & 2 & 66,7 & 1 & 33,3 & - & - & 3 & 100,0 \\
\hline $55-59$ & - & - & - & - & 1 & 100,0 & - & - & 1 & 100,0 \\
\hline $60-64$ & 1 & 33,3 & - & - & 1 & 3,33 & 1 & 3,33 & 3 & 100,0 \\
\hline Total & 11 & 17,7 & 30 & 48,4 & 15 & 24,2 & 6 & 9,7 & 62 & 100,0 \\
\hline
\end{tabular}

A tabela 15 demonstra a presença observada de fatores de retenção de biofilme dental. Observou-se que os 58 pacientes cardiopatas $(100,0 \%)$ apresentam um ou mais fatores de retenção de biofilme dental, e que o cálculo esteve presente em 100,0\% dos pacientes, restauração/prótese insatisfatória em 60,3\%, cárie em 
$51,7 \%$ e outros fatores em 1,7\%. Entre os pacientes não-cardiopatas, $51(82,3 \%)$ apresentam um ou mais fatores de retenção de biofilme dental, nos quais o cálculo esteve presente em $80,6 \%$, restauração/prótese insatisfatória em 22,6\%, cárie em $16,1 \%$ e outros fatores em $4,8 \%$.

Tabela 15 - Distribuição de pacientes submetidos à investigação periodontal, segundo o tipo de fator de retenção de biofilme dental. HCFMRP-USP, 2002.

\begin{tabular}{l|rr|rr}
\hline \multicolumn{1}{c|}{ Fator de retenção } & \multicolumn{2}{|c|}{ CARDIOPATAS } & \multicolumn{2}{c}{ NÃO-CARDIOPATA } \\
& $\mathrm{n}$ & \multicolumn{1}{c}{$\%$} & $\mathrm{n}$ & \multicolumn{1}{c}{${ }^{\prime}$} \\
\hline Cavidade cariosa & 30 & 51,7 & 10 & 16,1 \\
Cálculo dental & 58 & 100,0 & 50 & 80,6 \\
Restauração/prótese insatisfatória & 35 & 60,3 & 14 & 22,6 \\
Outros fatores & 1 & 1,7 & 3 & 4,8 \\
\hline \multicolumn{1}{c|}{ Total } & 58 & 100,0 & 51 & 82,3 \\
\hline
\end{tabular}

Segundo o número de dentes, observou-se que 20 pacientes cardiopatas (34,5\%) apresentavam 20 a 24 dentes, $30(51,7 \%) 25$ a 28 dentes, e $8(13,8 \%) 29$ a 32 dentes. Os valores da média e da mediana do número de dentes foram 25 e 26 , respectivamente. Entre os pacientes não-cardiopatas, observou-se que $10(16,1 \%)$ apresentavam 20 a 24 dentes, $32(51,6 \%) 25$ a 28 dentes, e $20(32,3 \%) 29$ a 32 . Os valores da média e da mediana do número de dentes foram 27 e 28 , respectivamente.

A tabela 16 demonstra os achados do número agrupado de dentes nos pacientes cardiopatas, segundo o sextante. 
Tabela 16 - Distribuição do número agrupado de dentes por sextante em pacientes cardiopatas submetidos à investigação periodontal. HCFMRP-USP, 2002.

\begin{tabular}{|c|c|c|c|c|c|c|c|}
\hline \multirow{2}{*}{$\begin{array}{c}\text { Número agrupado de } \\
\text { dentes }\end{array}$} & \multicolumn{6}{|c|}{ Sextante } & \multirow{2}{*}{ Total } \\
\hline & $\mathrm{SD}$ & SA & SE & ID & IA & $\mathrm{IE}$ & \\
\hline 0 & - & - & - & - & - & 2 & 2 \\
\hline $1-2$ & 5 & 3 & 6 & 12 & - & 13 & 39 \\
\hline $3-4$ & 33 & 3 & 38 & 40 & 1 & 37 & 152 \\
\hline $5-6$ & 20 & 52 & 14 & 6 & 57 & 6 & 155 \\
\hline Número de sextantes & 58 & 58 & 58 & 58 & 58 & 58 & 348 \\
\hline
\end{tabular}

Avaliando-se os sextantes com menor número de dentes, têm-se os inferiores esquerdo e direito como os mais mutilados, e os sextantes inferior anterior e superior anterior como os mais preservados. Observa-se que do total de 348 sextantes, 155 (44,5\%) têm 5 a 6 dentes, $152(43,7 \%)$ têm 3 a 4 dentes, 39 (11,2\%) têm 1 a 2 dentes, e $2(0,6 \%)$ não têm dentes.

A tabela 17 demonstra os achados do número agrupado de dentes nos pacientes não-cardiopatas, segundo o sextante.

Tabela 17 - Distribuição de pacientes não-cardiopatas submetidos à investigação periodontal do número agrupado de dentes, segundo o sextante. HCFMRP-USP, 2002.

\begin{tabular}{c|rrrrrrr}
\hline & \multicolumn{7}{|c}{ Sextante } \\
\multirow{nyyyyynn}{*}{$\begin{array}{c}\text { Número agrupado de } \\
\text { dentes }\end{array}$} & SD & SA & SE & ID & IA & IE & Total \\
\hline 0 & - & - & - & - & - & - & - \\
$1-2$ & 4 & 1 & 4 & 5 & - & 4 & 18 \\
$3-4$ & 41 & 3 & 44 & 41 & - & 47 & 176 \\
$5-6$ & 17 & 58 & 14 & 16 & 62 & 11 & 178 \\
\hline Número de sextantes & 62 & 62 & 62 & 62 & 62 & 62 & 372 \\
\hline
\end{tabular}


Avaliando-se o sextante com menor número de dentes, têm-se o inferior direito como o mais mutilado, e os sextantes inferior anterior e superior anterior como os mais preservados. Não se observou nenhum sextante com ausência total de dentes. Observa-se que do total de 372 sextantes, 178 (47,8\%) têm 5 a 6 dentes, 176 $(47,3 \%)$ têm 3 a 4 dentes, e $18(4,8 \%)$ têm 1 a 2 dentes.

A tabela 18 mostra os resultados segundo o Índice Periodontal Comunitário (IPC) entre os pacientes cardiopatas. $A$ amostra foi classificada quanto à presença de indicadores de saúde/doença, segundo o sextante. Observa-se saúde periodontal em 4 sextantes $(1,1 \%)$, sangramento à sondagem em 16 (4,6\%), cálculo em 60 (17,2\%), bolsa de 4 a $5 \mathrm{~mm}$ em 88 (25,3\%), bolsa $\geq 6 \mathrm{~mm}$ em $170(48,9 \%)$, e $10(2,9 \%)$ sextantes excluídos da investigação por apresentarem menos de 2 dentes.

Tabela 18 - Distribuição dos achados do Índice Periodontal Comunitário (IPC) em pacientes cardiopatas submetidos à investigação periodontal, segundo o sextante. HCFMRP-USP, 2002.

\begin{tabular}{c|rrrrrrr}
\hline \multirow{2}{*}{ Escore - IPC } & SD & SA & SE & ID & IA & IE & Total \\
\hline 0 & 2 & 1 & 1 & - & - & - & 4 \\
1 & 1 & 9 & 3 & 1 & - & 2 & 16 \\
2 & 3 & 16 & 2 & 7 & 24 & 8 & 60 \\
3 & 12 & 12 & 15 & 16 & 17 & 16 & 88 \\
4 & 39 & 18 & 36 & 31 & 17 & 29 & 170 \\
X & 1 & 2 & 1 & 3 & - & 3 & 10 \\
\hline Total & 58 & 58 & 58 & 58 & 58 & 58 & 348 \\
\hline
\end{tabular}

0=saúde periodontal; $1=$ sangramento à sondagem; $2=$ cálculo; $3=$ bolsa periodontal 4-5mm; 4=bolsa periodontal $\geq 6 \mathrm{~mm} ; \mathrm{X}=$ excluído.

A tabela 19 demonstra os resultados segundo o Índice Periodontal Comunitário (IPC) nos pacientes não-cardiopatas. A amostra foi classificada segundo a presença de indicadores de saúde/doença, segundo o sextante. Observa-se 
saúde periodontal em 119 sextantes (32,0\%), sangramento à sondagem em 55 (14,8\%), cálculo em $123(33,1 \%)$, bolsa de 4 a $5 \mathrm{~mm}$ em 58 (15,6\%), bolsa $\geq 6 \mathrm{~mm}$ em 17 (4,6\%), e nenhum sextante excluído da investigação por apresentar menos de 2 dentes.

Tabela 19 - Distribuição dos achados do Índice Periodontal Comunitário (IPC), em pacientes não-cardiopatas submetidos à investigação periodontal, segundo o sextante. HCFMRP-USP, 2002.

\begin{tabular}{c|rrrrrrr}
\hline \multirow{2}{*}{ Escore - IPC } & \multicolumn{7}{|c}{ Sextante } \\
SD & SA & SE & ID & IA & IE & Total \\
\hline 0 & 21 & 31 & 19 & 18 & 12 & 18 & 119 \\
1 & 10 & 9 & 12 & 12 & - & 12 & 55 \\
2 & 14 & 11 & 15 & 19 & 44 & 20 & 123 \\
3 & 14 & 10 & 13 & 10 & 2 & 9 & 58 \\
4 & 3 & 1 & 3 & 3 & 4 & 3 & 17 \\
X & - & - & - & - & - & - & - \\
\hline Total & 62 & 62 & 62 & 62 & 62 & 62 & 372 \\
\hline
\end{tabular}

0=saúde periodontal; $1=$ sangramento à sondagem; $2=$ cálculo; $3=$ bolsa periodontal de $4-5 \mathrm{~mm}$; $4=$ bolsa periodontal $\geq 6 \mathrm{~mm}$; $X=$ excluído.

Classificou-se a amostra segundo os escores do Índice Periodontal Comunitário (IPC), em distintos grupos etários, cujos resultados são apresentados na tabela 20. No grupo de pacientes cardiopatas, 10 (2,9\%) sextantes foram excluídos do exame periodontal por apresentarem 1 ou menos dentes. Observa-se que estão no escore 4 do IPC - pior condição de doença periodontal - 100,0\% dos 6 sextantes do grupo etário 30 a 34 anos, 66,7\% dos 18 sextantes do grupo etário 35 a 39 anos, $60,6 \%$ dos 66 sextantes do grupo etário 40 a 44 anos, 33,3\% dos 42 sextantes do grupo etário 45 a 49 anos, 35,0\% dos 60 sextantes do grupo etário 50 a 54 anos, 47,9\% dos 48 sextantes do grupo etário 55 a 59 anos, 56,7\% dos 60 sextantes do grupo etário 60 a 64 anos, 27,8\% dos 36 sextantes do grupo etário 65 a 69 anos, $66,6 \%$ dos 6 sextantes do grupo etário 70 a 74 anos, 100,0\% dos 6 sextantes do grupo 
etário 75 a 79 anos. Saúde periodontal $($ IPC $=0$ ) foi observada em 7,1\% dos 42 sextantes do grupo etário 45 a 49 anos, e 1,6\% dos 60 sextantes do grupo etário 60 a 64 anos.

Tabela 20 - Distribuição dos achados do Índice Periodontal Comunitário (IPC) em pacientes cardiopatas submetidos à investigação periodontal, segundo grupo etário. HCFMRP-USP, 2002.

\begin{tabular}{|c|c|c|c|c|c|c|c|c|c|c|c|c|c|c|}
\hline \multirow{3}{*}{$\begin{array}{l}\text { Grupo } \\
\text { Etário }\end{array}$} & \multicolumn{12}{|c|}{ Escore - IPC } & & \\
\hline & \multicolumn{2}{|c|}{0} & \multicolumn{2}{|c|}{1} & \multicolumn{2}{|c|}{2} & \multicolumn{2}{|r|}{3} & \multicolumn{2}{|c|}{4} & \multicolumn{2}{|c|}{$\mathrm{X}$} & \multicolumn{2}{|c|}{ Total } \\
\hline & $\mathrm{n}$ & $\%$ & $\mathrm{n}$ & $\%$ & $\mathrm{n}$ & $\%$ & $\mathrm{n}$ & $\%$ & $\mathrm{n}$ & $\%$ & $\mathrm{n}$ & $\%$ & $\mathrm{n}$ & $\%$ \\
\hline $30-34$ & - & - & - & - & - & - & - & - & 6 & 100,0 & - & - & 6 & 100,0 \\
\hline $35-39$ & - & - & - & - & 1 & 5,5 & 5 & 27,8 & 12 & 66,7 & - & - & 18 & 100,0 \\
\hline $40-44$ & - & - & 2 & 3,0 & 4 & 6,1 & 18 & 27,3 & 40 & 60,6 & 2 & 3,0 & 66 & 100,0 \\
\hline $45-49$ & 3 & 7,1 & 4 & 9,5 & 10 & 23,8 & 10 & 23,8 & 14 & 33,3 & 1 & 2,4 & 42 & 100,0 \\
\hline $50-54$ & - & - & - & - & 14 & 23,3 & 19 & 31,7 & 21 & 35,0 & 6 & 10 & 60 & 100,0 \\
\hline $55-59$ & - & - & 1 & 2,1 & 7 & 14,6 & 16 & 33,3 & 23 & 47,9 & 1 & 2,1 & 48 & 100,0 \\
\hline $60-64$ & 1 & 1,6 & 4 & 6,7 & 10 & 16,7 & 11 & 18,3 & 34 & 56,7 & - & - & 60 & 100,0 \\
\hline $65-69$ & - & - & 5 & 13,9 & 13 & 36,1 & 8 & 22,2 & 10 & 27,8 & - & - & 36 & 100,0 \\
\hline $70-74$ & - & - & - & - & 1 & 16,7 & 1 & 16,7 & 4 & 66,6 & - & - & 6 & 100,0 \\
\hline $75-79$ & - & - & - & - & - & - & - & - & 6 & 100,0 & - & - & 6 & 100,0 \\
\hline Total & 4 & 1,1 & 16 & 4,6 & 60 & 17,2 & 88 & 25,3 & 170 & 48,9 & 10 & 2,9 & 348 & 100,0 \\
\hline
\end{tabular}

0=saúde periodontal; $1=$ sangramento à sondagem; $2=$ cálculo; $3=$ =bolsa periodontal 4$5 \mathrm{~mm} ; 4=$ bolsa periodontal $\geq 6 \mathrm{~mm} ; \mathrm{X}=$ excluído

Do mesmo modo classificou-se a amostra de pacientes não-cardiopatas segundo os escores do Índice Periodontal Comunitário (IPC), em distintos grupos etários, cujos resultados são apresentados na tabela 21. Não se excluiu nenhum sextante neste grupo de pacientes. Observa-se que não há no escore 4 do IPC - pior condição de doença periodontal - nenhum dos 120 sextantes do grupo etário 30 a 34 anos; neste escore estão 7,8\% dos 90 sextantes do grupo etário de 35 a 39 anos, 5,9\% 84 sextantes do grupo etário de 40 a 44 anos, nenhum dos 36, 18 e 6 sextantes 
respectivamente dos grupos etários de 45 a 49 anos, 50 a 54 anos e 55 a 59 anos, $27,8 \%$ dos 18 sextantes do grupo etário de 60 a 64 anos. Saúde periodontal (IPC =0) foi observada em 20,8\% dos 120 sextantes do grupo etário 30 a 34 anos, 34,4\% dos 90 sextantes do grupo etário de 35 a 39 anos, 40,5\% dos 84 sextantes do grupo etário de 40 a 44 anos, $41,7 \%$ dos 36 sextanto do grupo etário 45 a 49 anos, 44,4\% dos 18 sextantes do grupo etário 50 a 54 anos, nenhum dos 6 sextantes do grupo etário 55 a 59 anos, e 33,3\% dos 18 sextantes do grupo etário de 60 a 64 anos.

Tabela 21 - Distribuição dos achados do Índice Periodontal Comunitário (IPC) em pacientes não-cardiopatas submetidos à investigação periodontal, segundo grupo etário. HCFMRP-USP, 2002.

\begin{tabular}{|c|c|c|c|c|c|c|c|c|c|c|c|c|}
\hline \multirow{3}{*}{$\begin{array}{l}\text { Grupo } \\
\text { Etário }\end{array}$} & \multicolumn{10}{|c|}{ Escore - IPC } & & \\
\hline & \multicolumn{2}{|c|}{0} & \multicolumn{2}{|c|}{1} & \multicolumn{2}{|c|}{2} & \multicolumn{2}{|c|}{3} & \multicolumn{2}{|c|}{4} & \multicolumn{2}{|c|}{ Total } \\
\hline & $\mathrm{n}$ & $\%$ & $\mathrm{n}$ & $\%$ & $\mathrm{n}$ & $\%$ & $\mathrm{n}$ & $\%$ & $\mathrm{n}$ & $\%$ & $\mathrm{n}$ & $\%$ \\
\hline $30-34$ & 25 & 20,8 & 21 & 17,5 & 59 & 49,2 & 15 & 12,5 & - & - & 120 & 32,2 \\
\hline $35-39$ & 31 & 34,4 & 18 & 20,0 & 23 & 25,6 & 11 & 12,2 & 7 & 7,8 & 90 & 24,2 \\
\hline $40-44$ & 34 & 40,5 & 10 & 11,9 & 19 & 22,6 & 16 & 19,0 & 5 & 5,9 & 84 & 22,6 \\
\hline $45-49$ & 15 & 41,7 & 1 & 2,8 & 13 & 36,1 & 7 & 19,4 & - & - & 36 & 9,7 \\
\hline $50-54$ & 8 & 44,4 & 2 & 11,1 & 6 & 33,3 & 2 & 11,1 & - & - & 18 & 4,8 \\
\hline $55-59$ & - & - & - & - & 2 & 33,3 & 4 & 66,7 & - & - & 6 & 1,6 \\
\hline $60-64$ & 6 & 33,3 & 3 & 16,7 & 1 & 5,5 & 3 & 16,7 & 5 & 27,8 & 18 & 4,8 \\
\hline Total & 119 & 32,0 & 55 & 14,8 & 123 & 33,1 & 58 & 15,6 & 17 & 4,6 & 372 & 100,0 \\
\hline
\end{tabular}

0=saúde periodontal; 1=sangramento à sondagem; $2=$ cálculo; $3=$ bolsa periodontal 4$5 \mathrm{~mm} ; 4=$ bolsa periodontal $\geq 6 \mathrm{~mm}$

A tabela 22 mostra os achados do Índice Periodontal Comunitário (IPC), segundo a arcada dentária, nos pacientes cardiopatas. Observou-se que dos 4 sextantes saudáveis, $100,0 \%$ são da arcada superior; dos 16 sextantes com sangramento à sondagem $81,2 \%$ são da arcada superior; dos 60 sextantes com cálculo 65,0\% são da arcada inferior; dos 88 sextantes com bolsa de 4 a 5mm 55,7\%

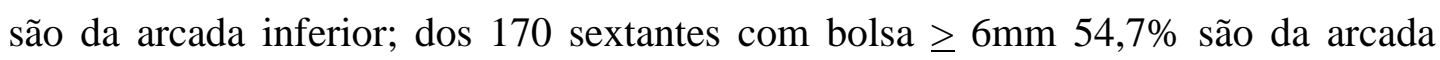


superior; dos 10 sextantes excluídos 60\% são da arcada inferior. Dos sextantes da arcada superior, $53,4 \%$ estão no escore 4 do IPC, $22,4 \%$ no escore $3,12,1 \%$ no escore $2,7,5 \%$ no escore $1,2,3 \%$ no escore 0 , e 2,3\% excluídos do exame. Dos sextantes da arcada inferior, 44,2\% estão no escore 4 do IPC, 28,2\% no escore 3 , $22,4 \%$ no escore $2,1,7 \%$ no escore 1 , nenhum sextante no escore 0 , e 3,5\% excluídos do exame.

Tabela 22 - Distribuição dos sextantes segundo o Índice Periodontal Comunitário (IPC) em pacientes cardiopatas submetidos à investigação periodontal, segundo a arcada dentário. HCFMRP-USP, 2002.

\begin{tabular}{|c|c|c|c|c|c|c|}
\hline \multirow[b]{3}{*}{ Escore - IPC } & \multicolumn{4}{|c|}{ Sextantes segundo a arcada dentária } & & \\
\hline & \multicolumn{2}{|c|}{ Superior } & \multicolumn{2}{|c|}{ Inferior } & \multicolumn{2}{|c|}{ Total } \\
\hline & $\mathrm{n}$ & $\%$ & $\mathrm{n}$ & $\%$ & $\mathrm{n}$ & $\%$ \\
\hline 0 & 4 & 2,3 & - & - & 4 & 1,1 \\
\hline 1 & 13 & 7,5 & 3 & 1,7 & 16 & 4,6 \\
\hline 2 & 21 & 12,1 & 39 & 22,4 & 60 & 17,2 \\
\hline 3 & 39 & 22,4 & 49 & 28,2 & 88 & 25,3 \\
\hline 4 & 93 & 53,4 & 77 & 44,2 & 170 & 48,9 \\
\hline $\mathrm{X}$ & 4 & 2,3 & 6 & 3,5 & 10 & 2,9 \\
\hline Total & 174 & 100,0 & 174 & 100,0 & 348 & 100,0 \\
\hline
\end{tabular}

A tabela 23 demonstra os achados do Índice Periodontal Comunitário( IPC), segundo a arcada dentária, nos pacientes não-cardiopatas. Observou-se que dos 119 (32,0\%) sextantes saudáveis, $71(59,6 \%)$ são da arcada superior; dos 55 (14,8\%) sextantes com sangramento à sondagem, 31 (56,4\%) são da arcada superior; dos 123 $(33,1 \%)$ sextantes com cálculo, $83(67,5 \%)$ são da arcada inferior; dos 58 (15,6\%) sextantes com bolsa de 4 a 5mm, 37 (63,8\%) são da arcada superior; dos 17 (4,5\%) sextantes com bolsa $\geq 6 \mathrm{~mm}, 10(58,8 \%)$ são da arcada inferior. Também se observa na arcada superior que $38,2 \%$ dos sextantes estão no escore 0 do IPC, 16,7\% no 
escore 1, 21,5\% no escore 2, 19,9\% no escore 3 e 3,7\% no escore 4. Da arcada inferior, $25,8 \%$ dos sextantes estão no escore 0 do IPC, $12,9 \%$ no escore $1,44,6 \%$ no escore 2, 11,3\% no escore 3 e 5,4\% no escore 4. Agrupando-se os escores 3 e 4 do IPC vê-se que aí estão contidos $23,6 \%$ dos sextantes da arcada superior e $16,7 \%$ dos sextantes da arcada inferior.

Tabela 23 - Distribuição dos sextantes segundo o Índice Periodontal Comunitário (IPC) em pacientes não-cardiopatas submetidos à investigação periodontal, segundo a arcada dentária. HCFMRP-USP, 2002.

\begin{tabular}{|c|c|c|c|c|c|c|}
\hline \multirow[b]{3}{*}{ Escore - IPC } & \multicolumn{6}{|c|}{ Sextantes segundo a arcada dentária } \\
\hline & \multicolumn{2}{|c|}{ Superior } & \multicolumn{2}{|c|}{ Inferior } & \multicolumn{2}{|c|}{ Total } \\
\hline & $\mathrm{n}$ & $\%$ & $\mathrm{n}$ & $\%$ & $\mathrm{n}$ & $\%$ \\
\hline 0 & 71 & 38,2 & 48 & 25,8 & 119 & 32,0 \\
\hline 1 & 31 & 16,7 & 24 & 12,9 & 55 & 14,8 \\
\hline 2 & 40 & 21,5 & 83 & 44,6 & 123 & 33,1 \\
\hline 3 & 37 & 19,9 & 21 & 11,3 & 58 & 15,6 \\
\hline 4 & 7 & 3,7 & 10 & 5,4 & 17 & 4,5 \\
\hline $\mathrm{X}$ & - & - & - & - & - & - \\
\hline Total & 186 & 100,0 & 186 & 100,0 & 372 & 100,0 \\
\hline
\end{tabular}

$0=$ saúde periodontal; $1=$ =sangramento à sondagem; $2=$ cálculo; $3=$ bolsa periodontal de 4-5mm; 4=bolsa periodontal $\geq 6 \mathrm{~mm}$; $X=$ excluído.

Mesmo não apresentados em tabelas, os resultados permitiram observar entre os pacientes cardiopatas:

- $\quad$ agrupando os escores do IPC condizentes com situação de saúde e grau mínimo de necessidade periodontal (IPC = 0, 1 e 2), têm-se 80 sextantes (23,0\%). Agrupando os escores do IPC condizentes com grau máximo de necessidade periodontal (IPC $=3$ e 4), têm-se 258 sextantes $(74,1 \%)$. Houve exclusão de 2,9\% dos sextantes. 
- agrupando os sextantes anteriores superior e inferior (114), segundo os escores do IPC condizentes com situação de saúde e mínima necessidade periodontal (IPC $=0,1$ e 2), têm-se 50 sextantes (43,9\%). Agrupando os escores do IPC condizentes com graus máximos de necessidade periodontal (IPC $=3$ e 4) nestes mesmos sextantes, têm-se 64 sextantes $(56,1 \%)$.

- $\quad$ agrupando os sextantes posteriores superiores e inferiores (234), segundo os escores do IPC condizentes com situação de saúde e mínima necessidade periodontal (IPC $=0,1$ e 2), têm-se 30 sextantes (12,8\%). Agrupando os escores do IPC condizentes com graus máximos de necessidade periodontal (IPC $=3$ e 4 ) nestes mesmos sextantes, têm-se 194 sextantes (82,9\%). Houve exclusão de 10 sextantes $(4,3 \%)$.

- agrupando os participantes segundo a necessidade de tratamento periodontal, considerando-se o grau mínimo de necessidade (IPC $=1$ e 2 ) e o grau máximo de necessidade (IPC $=3$ e 4), têm-se $3(5,2 \%)$ e 55 pacientes $(94,8 \%)$, respectivamente.

- $\quad$ o número de pacientes com bolsa periodontal $\geq 6 \mathrm{~mm}$ em pelo menos um sextante $(\mathrm{IPC}=4)$ foi $46(79,3 \%)$.

- $\quad$ há entre os pacientes cardiopatas, $9(15,5 \%)$ com escore 4 do IPC nos 6 sextantes, e nenhum paciente com escore 0 do IPC nos 6 sextantes.

Os resultados do exame periodontal entre os pacientes não-cardiopatas, não apresentados em tabelas, permitiram observar:

- $\quad$ agrupando os escores do IPC condizentes com situação de saúde e grau mínimo de necessidade periodontal (IPC $=0,1$ e 2), têm-se 297 sextantes $(79,8 \%)$. Agrupando os escores do IPC condizentes com grau máximo de necessidade periodontal (IPC $=3$ e 4), têm-se 75 sextantes $(20,2 \%)$. 
- $\quad$ agrupando os sextantes anteriores superior e inferior (124), segundo os escores do IPC condizentes com situação de saúde e mínima necessidade periodontal (IPC $=0,1$ e 2), têm-se 107 sextantes (86,3\%). Agrupando os escores do IPC condizentes com graus máximos de necessidade periodontal (IPC $=3$ e 4) nestes mesmos sextantes, têm-se 17 sextantes $(13,7 \%)$.

- $\quad$ agrupando os sextantes posteriores superiores e inferiores (248), segundo os escores do IPC condizentes com situação de saúde e mínima necessidade periodontal (IPC $=0,1$ e 2), têm-se 190 sextantes (76,6\%). Agrupando os escores do IPC condizentes com graus máximos de necessidade periodontal (IPC $=3$ e 4 ) nestes mesmos sextantes, têm-se 58 sextantes $(23,4 \%)$.

- agrupando os participantes segundo a necessidade de tratamento periodontal, considerando-se a ausência de necessidade, o grau mínimo de necessidade (IPC $=1$ e 2) e o grau máximo de necessidade (IPC = 3 e 4), têm-se 11 $(17,7 \%), 30(48,4 \%)$ e 21 pacientes $(33,9 \%)$, respectivamente.

- $\quad$ o número de pacientes com bolsa periodontal $\geq 6 \mathrm{~mm}(\mathrm{IPC}=4)$ em pelo menos um sextante, foi $6(9,7 \%)$.

- há entre os pacientes não-cardiopatas, 1 paciente $(1,6 \%)$ com escore 4 do IPC nos 6 sextantes, e 11 pacientes $(17,7 \%)$ com escore 0 do IPC nos 6 sextantes.

Quanto a variável que estima a destruição acumulada durante a vida útil da inserção periodontal, Perda de Inserção (PI), segundo o sextante, a tabela 24 mostra os resultados obtidos no exame periodontal dos pacientes cardiopatas. Observou-se 21 sextantes $(6,0 \%)$ sem perda de inserção, $103(29,6 \%)$ com perda de inserção de 4 a 5mm, $149(42,8 \%)$ com perda de inserção de 6 a 8mm, 57 (16,4\%) com perda de inserção de 9 a 11mm, 8 (2,3\%) com perda de inserção de $12 \mathrm{~mm}$ ou mais, e 10 $(2,9 \%)$ sextantes excluídos do exame. 
Tabela 24 - Distribuição dos achados da Perda de Inserção (PI) em pacientes cardiopatas submetidos à investigação periodontal, segundo o sextante. HCFMRPUSP, 2002.

\begin{tabular}{c|ccccccc}
\hline \multirow{2}{*}{ Escore - PI } & SD & SA & SE & ID & IA & IE & Total \\
\hline 0 & 2 & 11 & 2 & - & 6 & - & 21 \\
1 & 10 & 26 & 11 & 17 & 23 & 16 & 103 \\
2 & 29 & 14 & 30 & 26 & 20 & 30 & 149 \\
3 & 14 & 4 & 10 & 11 & 9 & 9 & 57 \\
4 & 2 & 1 & 4 & 1 & - & - & 8 \\
$X$ & 1 & 2 & 1 & 3 & - & 3 & 10 \\
\hline Total & 58 & 58 & 58 & 58 & 58 & 58 & 348 \\
\hline 0=0 a 3mm (JAC não visível e IPC 0-3mm); 1=4 a 5mm (JAC na tarja); 2=6 a $8 \mathrm{~mm}$ \\
(JAC entre tarja e anel 8,5mm); 3=9 a 11mm (JAC entre anéis 8,5-11mm; 4=12 ou \\
+ mm (JAC além do anel de 11mm); X=excluído.
\end{tabular}

Ainda quanto a variável que estima a destruição acumulada durante a vida útil da inserção periodontal, Perda de Inserção (PI), segundo o sextante, a tabela 25 mostra os resultados obtidos no exame periodontal dos pacientes não-cardiopatas. Observou-se 253 sextantes $(68,0 \%)$ sem perda de inserção, 91 sextantes $(24,5 \%)$ com perda de inserção de 4 a 5mm e 28 sextantes $(7,5 \%)$ com perda de inserção de 6 a $8 \mathrm{~mm}$. 
Tabela 25 - Distribuição dos achados da Perda de Inserção (PI) em pacientes nãocardiopatas submetidos à investigação periodontal, segundo o sextante. HCFMRPUSP, 2002.

\begin{tabular}{c|rrrrrrc}
\hline \multirow{2}{*}{ Escore - PI } & SD & SA & SE & ID & IA & IE & Total \\
\hline 0 & 37 & 48 & 36 & 42 & 45 & 45 & 253 \\
1 & 20 & 11 & 21 & 15 & 13 & 11 & 91 \\
2 & 5 & 3 & 5 & 5 & 4 & 6 & 28 \\
3 & - & - & - & - & - & - & - \\
4 & - & - & - & - & - & - & - \\
X & - & - & - & - & - & - & - \\
\hline Total & 62 & 62 & 62 & 62 & 62 & 62 & 372 \\
\hline
\end{tabular}

$0=0$ a $3 \mathrm{~mm}$ (JAC não visível e IPC 0-3mm); 1=4 a 5mm (JAC na tarja); $2=6$ a 8mm (JAC entre tarja e anel 8,5mm); $3=9$ a $11 \mathrm{~mm}$ (JAC entre anéis 8,5-11mm; 4=12 ou $+\mathrm{mm}$ (JAC além do anel de $11 \mathrm{~mm}) ; \mathrm{X}=$ excluído.

Classificou-se a amostra segundo os escores da Perda de Inserção periodontal (PI), em distintos grupos etários, cujos resultados são apresentados na tabela 26. No grupo de pacientes cardiopatas, observou-se 10 (2,9\%) sextantes excluídos por apresentar 1 ou menos dentes. Estabelecendo-se como condições aceitáveis para a estabilidade funcional dos elementos dentários, sem uso de recursos terapêuticos (por exemplo, esplintagem ou estabilização dentária), ausência de perda de inserção ou uma perda até $5 \mathrm{~mm}(\mathrm{PI}=0$ e 1$)$, observou-se que extrapolaram essa condição $100,0 \%$ dos 6 sextantes do grupo etário 30 a 34 anos; 61,1\% dos 18 sextantes do grupo etário 35 a 39 anos; $75,7 \%$ dos 66 sextantes do grupo etário 40 a 44 anos; 40,5\% dos 42 sextantes do grupo etário 45 a 49 anos; 60,0\% dos 60 sextantes do grupo etário 50 a 54 anos; $70,8 \%$ dos 48 sextantes do grupo etário 55 a 59 anos; 71,7\% dos 60 sextantes do grupo etário 60 a 64 anos; 44,4\% dos 36 sextantes do grupo etário 65 a 69 anos; $50,0 \%$ dos 6 sextantes do grupo etário 70 a 74 anos; $100,0 \%$ dos 6 sextantes do grupo etário 75 a 79 anos. 
Tabela 26 - Distribuição dos achados da Perda de Inserção periodontal (PI) em pacientes cardiopatas submetidos à investigação periodontal, segundo grupo etário. HCFMRP-USP, 2002.

\begin{tabular}{|c|c|c|c|c|c|c|c|c|c|c|c|c|c|c|c|}
\hline \multirow{3}{*}{$\begin{array}{l}\text { Faixa } \\
\text { Etária }\end{array}$} & \multicolumn{13}{|c|}{ Escore - PI } & & \\
\hline & \multicolumn{2}{|c|}{0} & \multicolumn{2}{|c|}{1} & \multicolumn{2}{|c|}{2} & \multicolumn{2}{|r|}{3} & \multicolumn{3}{|c|}{4} & \multicolumn{2}{|c|}{$\mathrm{X}$} & \multicolumn{2}{|c|}{ Total } \\
\hline & $\mathrm{n}$ & $\%$ & $\mathrm{n}$ & $\%$ & $\mathrm{n}$ & $\%$ & $\mathrm{n}$ & $\%$ & r & $\%$ & $\%$ & $\mathrm{n}$ & $\%$ & $\mathrm{n}$ & $\%$ \\
\hline $30-34$ & - & - & - & - & 6 & 100 & - & & & & - & - & - & 6 & 100,0 \\
\hline $35-39$ & - & - & 7 & 38,9 & 9 & 50,0 & 2 & 11,1 & & & - & - & - & 18 & 100,0 \\
\hline $40-44$ & 2 & 3,0 & 14 & 21,2 & 37 & 56,1 & 9 & 13,6 & 2 & & 3,0 & 2 & 3,0 & 66 & 100,0 \\
\hline $45-49$ & 8 & 19,0 & 17 & 40,5 & 14 & 33,3 & 2 & 4,8 & 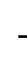 & - & - & 1 & 2,4 & 42 & 100,0 \\
\hline $50-54$ & 3 & 5,0 & 19 & 31,7 & 20 & 33,3 & 9 & 15,0 & 3 & & 5,0 & 6 & 10 & 60 & 100,0 \\
\hline $55-59$ & 2 & 4,2 & 12 & 25,0 & 20 & 41,6 & 12 & 25,0 & & & 2,1 & 1 & 2,1 & 48 & 100,0 \\
\hline $60-64$ & 6 & 10,0 & 11 & 18,3 & 25 & 41,7 & 17 & 28,3 & & & 1,7 & - & - & 60 & 100,0 \\
\hline $65-69$ & - & - & 20 & 55,5 & 12 & 33,3 & 4 & 11,1 & - & & - & - & - & 36 & 100,0 \\
\hline $70-74$ & - & - & 3 & 50,0 & 3 & 50,0 & - & - & 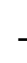 & & - & - & - & 6 & 100,0 \\
\hline $75-79$ & - & - & - & - & 3 & 50,0 & 2 & 33,3 & & & 6,7 & - & - & 6 & 100,0 \\
\hline Total & 21 & 6,0 & 103 & 29,6 & 149 & 42,8 & 57 & 16,4 & $c$ & & 2,3 & 10 & 2,9 & 348 & 100,0 \\
\hline
\end{tabular}

0=0 a 3mm (JAC não visível e IPC 0-3mm); 1=4 a 5mm (JAC na tarja); $2=6$ a $8 \mathrm{~mm}$ (JAC entre tarja e anel 8,5mm); 3=9 a $11 \mathrm{~mm}$ (JAC entre anéis 8,5-11mm; 4=12 ou + $\mathrm{mm}$ (JAC além do anel de $11 \mathrm{~mm}$ ); X=excluído

Do mesmo modo, classificou-se a amostra de pacientes não-cardiopatas segundo os escores da Perda de Inserção periodontal (PI), em distintos grupos etários, cujos resultados são apresentados na tabela 27. Também se estabelecendo como condições aceitáveis para a estabilidade funcional dos elementos dentários, sem uso de recursos terapêuticos (por exemplo, esplintagem ou estabilização dentária), ausência de perda de inserção ou uma perda até $5 \mathrm{~mm}(\mathrm{PI}=0$ e 1), observou-se que extrapolaram essa condição 7,8\% dos 90 sextantes do grupo etário 35 a 39 anos; 9,5\% dos 84 sextantes do grupo etário 40 a 44 anos; 22,2\% dos sextantes do grupo etário 45 a 49 anos; 27,8\% dos sextantes do grupo etário 60 a 64 anos. 
Tabela 27 - Distribuição dos achados da Perda de Inserção periodontal (PI) em pacientes não-cardiopatas submetidos à investigação periodontal, segundo grupo etário. HCFMRP-USP, 2002.

\begin{tabular}{|c|c|c|c|c|c|c|c|c|c|c|c|c|}
\hline \multirow{3}{*}{$\begin{array}{l}\text { Faixa } \\
\text { Etária }\end{array}$} & \multicolumn{10}{|c|}{ Escore - PI } & & \\
\hline & \multicolumn{2}{|c|}{0} & \multicolumn{2}{|c|}{1} & \multicolumn{2}{|r|}{2} & \multicolumn{2}{|c|}{3} & \multicolumn{2}{|c|}{4} & \multicolumn{2}{|c|}{ Total } \\
\hline & $\mathrm{n}$ & $\%$ & $\mathrm{n}$ & $\%$ & $\mathrm{n}$ & $\%$ & $\mathrm{n}$ & $\%$ & $\mathrm{n}$ & $\%$ & $\mathrm{n}$ & $\%$ \\
\hline $30-34$ & 105 & 87,5 & 15 & 12,5 & - & - & - & - & - & - & 120 & 100,0 \\
\hline $35-39$ & 62 & 68,9 & 21 & 23,3 & 7 & 7,8 & - & - & - & - & 90 & 100,0 \\
\hline $40-44$ & 56 & 66,7 & 20 & 23,8 & 8 & 9,5 & - & - & - & - & 84 & 100,0 \\
\hline $45-49$ & 16 & 44,4 & 12 & 33,3 & 8 & 22,2 & - & - & - & - & 36 & 100,0 \\
\hline $50-54$ & 8 & 44,4 & 10 & 55,6 & - & - & - & - & - & - & 18 & 100,0 \\
\hline $55-59$ & 1 & 16,7 & 5 & 83,3 & - & - & - & - & - & - & 6 & 100,0 \\
\hline $60-64$ & 5 & 27,8 & 8 & 44,4 & 5 & 27,8 & - & - & - & - & 18 & 100,0 \\
\hline Total & 253 & 68,0 & 91 & 24,5 & 28 & 7,5 & - & - & - & - & 372 & 100,0 \\
\hline
\end{tabular}

Avaliando-se a Perda de Inserção (PI) segundo a arcada dentária (tabela 28), entre os pacientes cardiopatas observa-se que dos 23 sextantes sem perda de inserção 71,4\% são da arcada superior; dos 103 sextantes com perda de inserção de 4 a $5 \mathrm{~mm}$ 54,4\% são da arcada inferior; dos 149 sextantes com perda de inserção de 6 a $8 \mathrm{~mm}$ 51,0\% são da arcada inferior; dos 57 sextantes com perda de inserção de 9 a $11 \mathrm{~mm}$ $50,9 \%$ são da arcada inferior; dos 8 sextantes com perda de inserção de $12 \mathrm{~mm}$ ou mais $87,5 \%$ são da arcada superior; dos 10 sextantes excluídos $60 \%$ são da arcada inferior.

Neste grupo de pacientes também se observa que $41,9 \%$ dos sextantes da arcada superior estão no escore 2 da PI; 43,7\% dos sextantes da arcada inferior estão no escore 2 da PI. Somente 6,0\% dos sextantes não exibem perda de inserção, sendo 71,4\% na arcada superior. Agrupando as categorias "sem perda de inserção" e "perda de inserção entre 4 e 5mm", têm-se 124 sextantes (36,7\%). Quando se agrupa as 
categorias relativas a perda de inserção de $6 \mathrm{~mm}$ e mais, têm-se 214 sextantes $(63,3 \%)$.

Tabela 28 - Distribuição dos sextantes de pacientes cardiopatas submetidos à investigação periodontal segundo a Perda de Inserção (PI), segundo a arcada dentária. HCFMRP-USP, 2002.

\begin{tabular}{|c|c|c|c|c|c|c|}
\hline \multirow[b]{3}{*}{ Escore - PI } & \multicolumn{4}{|c|}{ Sextantes segundo a arcada dentária } & & \\
\hline & \multicolumn{2}{|c|}{ Superior } & \multicolumn{2}{|c|}{ Inferior } & \multicolumn{2}{|c|}{ Total } \\
\hline & $\mathrm{n}$ & $\%$ & $\mathrm{n}$ & $\%$ & $\mathrm{n}$ & $\%$ \\
\hline 0 & 15 & 8,6 & 6 & 3,4 & 21 & 6,0 \\
\hline 1 & 47 & 27,0 & 56 & 32,2 & 103 & 29,6 \\
\hline 2 & 73 & 41,9 & 76 & 43,7 & 149 & 42,8 \\
\hline 3 & 28 & 16,1 & 29 & 16,7 & 57 & 16,4 \\
\hline 4 & 7 & 4,0 & 1 & 0,6 & 8 & 2,3 \\
\hline$X$ & 4 & 2,3 & 6 & 3,4 & 10 & 2,9 \\
\hline Total & 174 & 100,0 & 174 & 100,0 & 348 & 100,0 \\
\hline
\end{tabular}

Avaliando-se a Perda de Inserção (PI) segundo a arcada dentária (tabela 29), entre os pacientes não-cardiopatas observa-se que dos 253 sextantes com perda de inserção de 0 a 3mm, 52,2\% (132) são da arcada inferior; dos 91 sextantes com perda de inserção de 4 a 5mm 57,1\% (52) são da arcada superior; dos 28 sextantes com perda de inserção de 6 a 8mm 53,6\% (15) são da arcada inferior. Não se observou maiores níveis de perda de inserção neste grupo de pacientes. Também se observa que da arcada superior $65,1 \%$ (121) dos sextantes estão no escore 0 do PI, 27,9\% (52) no escore 1, 7,0\% (13) no escore 2. Da arcada inferior, 71,0\% (132) dos sextantes estão no escore 0 do PI, 21,0\% (39) no escore 1 e 8,0\% (15) no escore 2 do PI. Contrariamente ao observado entre os pacientes cardiopatas, neste grupo há um percentual elevado $(68,0 \%$ - 253/372) de sextantes sem perda de inserção (0 a 3mm), 
sendo 52,2\% (132) no arco inferior. Agrupando as categorias "sem perda de inserção" e "perda de inserção entre 4 e 5mm", têm-se 344 sextantes (92,5\%). Quando se agrupam as categorias relativas a perda de inserção de $6 \mathrm{~mm}$ e mais, têmse 28 sextantes (7,5\%). Esses achados estão descritos na tabela 23 .

Tabela 29 - Distribuição dos sextantes de pacientes não-cardiopatas submetidos à investigação periodontal segundo a Perda de Inserção - PI, segundo a arcada dentária. HCFMRP-USP, 2002.

\begin{tabular}{|c|c|c|c|c|c|c|}
\hline \multirow[b]{3}{*}{ Escore - PI } & \multicolumn{6}{|c|}{ Sextantes segundo a arcada dentária } \\
\hline & \multicolumn{2}{|c|}{ Superior } & \multicolumn{2}{|c|}{ Inferior } & \multicolumn{2}{|c|}{ Total } \\
\hline & $\mathrm{n}$ & $\%$ & $\mathrm{n}$ & $\%$ & $\mathrm{n}$ & $\%$ \\
\hline 0 & 121 & 65,1 & 132 & 71,0 & 253 & 68,0 \\
\hline 1 & 52 & 27,9 & 39 & 21,0 & 91 & 24,5 \\
\hline 2 & 13 & 7,0 & 15 & 8,0 & 28 & 7,5 \\
\hline 3 & - & - & - & - & - & - \\
\hline 4 & - & - & - & - & - & - \\
\hline$X$ & - & - & - & - & - & - \\
\hline Total & 186 & 100,0 & 186 & 100,0 & 372 & 100,0 \\
\hline
\end{tabular}

Segundo o local de exame periodontal, a amostra foi classificada em "HCFMRP-USP" e “consultório particular". Dos 58 pacientes cardiopatas, 40 $(69,0 \%)$ foram examinados no HCFMRP-USP e 18 (31,0\%) o foram no consultório particular da autora deste estudo. Cabe ressaltar que os participantes que concordaram em se deslocar para o exame periodontal receberam procedimentos de raspagem ultra-sônica e orientações quanto ao processo saúde-doença periodontal e de higiene bucal. Os pacientes não-cardiopatas foram, em sua totalidade, examinados no HCFMRP-USP. Todos os pacientes examinados foram orientados quanto aos serviços de que necessitavam. 
Completada a demonstração dos achados em ambos os grupos, considerou-se interessante o cotejamento de alguns desses achados entre eles, resumido a seguir.

No tocante à idade, observou-se que os pacientes cardiopatas têm valores da média e da mediana significativamente superiores aos dos pacientes não-cardiopatas $(\mathrm{p}<0,0001)$. Houve predomínio do sexo masculino em ambos os grupos $(82,8 \%$ entre pacientes cardiopatas e 74,2\% em pacientes não-cardiopatas); de pessoas acima de 40 anos $(89,6 \%)$ entre os pacientes cardiopatas e de pessoas abaixo de 45 anos $(79,0 \%)$ entre os pacientes não-cardiopatas.

Quanto ao número de escovações diárias, embora os pacientes nãocardiopatas apresentem percentual mais elevado de 3 ou mais escovações diárias $(71,0 \%$ contra $53,4 \%)$, essa diferença não se mostra significativa $(p=0,139)$.

O conhecimento prévio sobre a existência da doença periodontal, tendo como fonte de informações os profissionais da área odontológica, mostrou percentuais de $25,9 \%$ entre os pacientes cardiopatas e 33,9\% entre os pacientes não-cardiopatas. Essa diferença não tem significância estatística. Por outro lado, percentuais de desconhecimento completo atingem valores muito semelhantes, ou seja, $13,8 \%$ e $12,9 \%(\mathrm{p}=0,629)$.

Com relação ao hábito de fumar, observou-se que a prevalência de tabagismo foi de $10,4 \%$ entre os pacientes cardiopatas e de $33,9 \%$ entre os pacientes nãocardiopatas. O percentual de ex-tabagistas é mais elevado entre os pacientes cardiopatas $(58,6 \%$ contra 22,6\%). A análise estatística mostra forte associação entre as variáveis $(\mathrm{p}<0,0001)$.

O hábito diário de escovação foi observado em 96,5\% dos pacientes cardiopatas e em $96,8 \%$ dos pacientes não-cardiopatas. Com relação ao uso de acessórios de higiene bucal (limpador de língua, waterpick, palito dental, escova interproximal e bitufo, etc.), observou-se que 55,2\% dos pacientes cardiopatas e 
48,4\% dos pacientes não-cardiopatas fazem uso regular de palito dental apenas. Essas diferenças não mostram significância estatística.

Quanto ao uso diário de fio/fita dental, observou-se percentuais muito próximos em ambos os grupos (37,1\% entre os pacientes cardiopatas e 32,7\% entre os pacientes não-cardiopatas). Agrupando-se as categorias "não usa" e "uso eventual", obteve-se $\mathrm{p}=0,619$.

Quanto à presença de fatores de retenção de biofilme dental, houve um predomínio de todos entre os pacientes cardiopatas, exceção feita apenas ao apinhamento dental. Ausência desses fatores foi observada apenas em 11 pessoas, todas pertencentes ao grupo de pacientes não-cardiopatas. A análise estatística mostra associação entre as variáveis $(\mathrm{p}=0,001)$.

Segundo a presença e gravidade da doença periodontal, mensuradas através do IPC, em pacientes cardiopatas a doença apresentou-se no seu grau mais avançado $($ IPC $=4)$ em $48,9 \%$ dos sextantes, no grau moderado (IPC $=3$ ) em $25,3 \%$ e no grau leve (IPC $=1$ ou 2 ) em $21,8 \%$. Chama a atenção que apenas $1,1 \%$ dos sextantes exibiram saúde periodontal (IPC $=0)$ e 2,9\% (10/348) mostraram um máximo de 1 dente. Em pacientes não-cardiopatas, a doença periodontal apresentou-se no seu grau mais avançado (IPC $=4)$ em 4,6\% dos sextantes, no grau moderado (IPC $=3$ ) em $15,6 \%$ e no grau leve (IPC $=1$ ou 2 ) em $47,8 \%$. Chama a atenção que $32,0 \%$ dos sextantes exibiram saúde periodontal (IPC $=0$ ), não se verificando sextante com um mínimo de 1 dente. Agrupando-se ausência de necessidade e necessidades mínimas (IPC $=0,1$ e 2 ) e as categorias indicativas de maiores necessidades (IPC $=3$ e 4 ), observa-se diferenças com significância estatística $(\mathrm{p}<0,00001)$.

Segundo a história pregressa da doença periodontal, mensuradas através da perda de inserção periodontal (PI), entre os pacientes cardiopatas apenas 6,0\% dos sextantes não exibiram perda de inserção contra 68,0\% entre os pacientes nãocardiopatas. Em contrapartida, valores de PI iguais ou superiores a 2, indicativos de acentuada perda de inserção representaram $61,5 \%$ entre os pacientes cardiopatas e $7,5 \%$ entre os pacientes não-cardiopatas. Agrupando-se as categorias "sem perda de inserção" e "perda de inserção de 4 a $5 \mathrm{~mm}$ " e as categorias relativas a perda de 
inserção acima de 6mm, observa-se diferença com significância estatística (p < $0,00001)$.

Segundo a necessidade de tratamento, observou-se pessoas sem necessidade de qualquer outra modalidade de tratamento odontológico apenas entre os nãocardiopatas $(17,7 \%)$. A análise da necessidade ou não de tratamento entre os dois grupos estudados mostra que os pacientes cardiopatas apresentam percentual significativamente mais elevado de necessidade $(p=0,001)$.

Com necessidade de tratamento periodontal em grau mínimo (raspagem de cálculo em sítios com profundidade de sondagem até $3 \mathrm{~mm}$ ), observou-se uma freqüência de 5,2\% entre os pacientes cardiopatas e de 58,8\% entre os pacientes nãocardiopatas. A análise das necessidades mínimas evidenciou percentuais significativamente mais elevados entre os pacientes não-cardiopatas $(\mathrm{p}<0,0001)$.

A comparação dos grupos em relação à necessidade de tratamento periodontal em grau máximo (tratamento de bolsa de $4 \mathrm{~mm}$ e mais), mostrou percentual significativamente mais elevado entre os pacientes cardiopatas $(94,8 \%$ entre os pacientes cardiopatas contra 33,9\% entre os pacientes não-cardiopatas), diferença essa sem significância estatística $(\mathrm{p}<0,00001)$.

Necessitam de tratamento de bolsa de 4 a $5 \mathrm{~mm}$ 15,5\% dos pacientes cardiopatas e $24,2 \%$ dos pacientes não-cardiopatas.

Necessitam de tratamento de bolsa $\geq 6 \mathrm{~mm} 79,3 \%$ dos pacientes cardiopatas e 9,7\% dos pacientes não-cardiopatas, diferença estatisticamente significante $(\mathrm{p}<$ $0,00001)$. 


\section{DISCUSSÃO}

\subsection{RELEVÂNCIA}

Inúmeros estudos epidemiológicos demonstram a alta prevalência das diversas formas das doenças periodontais em pessoas jovens, adultas e idosas, em todo o mundo. Indicam, também, que portadores de doenças periodontais estão expostos às endotoxinas de muitas espécies de microorganismos anaeróbios associados à essas doenças e que essas endotoxinas afetam a integridade do endotélio, as lipoproteínas do plasma, a coagulação sanguiínea e a função plaquetária (DeEstefano, $1993^{34}$; Genco, $1997^{39}$; Herzberg \& Meyer, $1998^{46}$; Joshipura et al., $1996^{48}$; Loesche, $1995^{59}$; Mattila et al., $1995^{64}$; Mealey, $19966^{66}$ ).

Devido a recentes estudos indicarem a forte associação da doença periodontal com doença cardiovascular aterosclerótica, planejou-se conhecer a prevalência e gravidade das doenças periodontais em pacientes portadores desta doença, atendidos no Ambulatório de Cardiologia do Hospital das Clínicas da Faculdade de Medicina de Ribeirão Preto da Universidade de São Paulo, cotejando os dados obtidos com os de pacientes não-cardiopatas da mesma instituição. 


\subsection{INSTRUMENTO DE MEDIDA DAS DOENÇAS PERIODONTAIS}

No planejamento inicial da pesquisa deparou-se com uma dificuldade relacionada à escolha do instrumento de medida da doença periodontal, pois, apesar da sua elevada prevalência, divergências conceituais e quanto à metodologia para sua avaliação, dificultaram a escolha do índice. Para ser útil e eficaz, Pinto (2000) ${ }^{84}$ considera que o índice utilizado deve registrar não só a presença ou ausência de doença, mas também dar idéia da sua gravidade nos indivíduos atingidos.

Uma maneira de avaliar a doença periodontal é através do diagnóstico de suas várias formas e freqüências. Este método pressupõe um diagnóstico clínico, para o qual se necessita de exame cuidadoso, detalhado e demorado, com utilização de recursos auxiliares, tais como radiografias, além de exigir a classificação das doenças periodontais. No entanto, apesar de esforços contínuos, até o momento persistem discordâncias entre os especialistas quanto à terminologia e classificação. Por conseguinte, torna-se difícil comparar estudos baseados na classificação da doença, enquanto existam essas divergências (Pinto, $2000^{84}$ ).

Outra forma de medir as doenças periodontais é através dos seus sinais objetivos. Esta forma é considerada mais lógica, pois do ponto de vista epidemiológico se considera mais importante medir o grau de saúde das estruturas periodontais do que propriamente a freqüência relativa das variadas formas da doença (Pinto, $2000^{84}$ ).

Analisando a história natural da doença periodontal como uma seqüência de lesões progressivas, que se iniciam na gengiva e terminam com a destruição das estruturas de suporte dos dentes e sua conseqüente perda, índices foram propostos a partir dos distintos sinais da doença. Entretanto, nenhum dos seus sinais é patognomônico. Portanto, deve-se avaliar a sucessão de sinais da doença nas distintas fases de sua evolução, desde a lesão gengival (representada pela inflamação), à perda óssea, formação de bolsas, migração dentária e incapacidade funcional dos dentes afetados. Esta sequiência de eventos é observada nas formas mais comuns da doença 
periodontal (aquelas produzidas por irritantes locais), e com melhores possibilidades de sucesso após terapia periodontal.

Pelo exposto, considera-se que o exame da condição periodontal deveria incluir a avaliação clínica da inflamação dos tecidos periodontais, o registro da profundidade de sondagem, o registro do nível clínico de inserção e a avaliação radiográfica do osso alveolar. Variados sistemas para quantificação desses parâmetros foram desenvolvidos ao longo dos anos. Alguns desses foram estruturados para uso clínico, enquanto outros o foram para estudos epidemiológicos (Ainamo et al., $1982^{2}$; Papapanou \& Baelum, $1996^{79}$; Ramfjord \& Ash, $1991^{85}$ ).

Por iniciativa da Organização Mundial de Saúde (OMS), em 1982, Ainamo et al. ${ }^{2}$ desenvolveram um índice para avaliação das necessidades de tratamento periodontal em grupos de população, denominado Community Periodontal Index of Treatment Needs ou Índice das Necessidades de Tratamento Periodontal da Comunidade (CPITN). Apesar de não ter sido planejado com propósitos epidemiológicos, este índice foi extensivamente utilizado em todo o mundo, em especial nos países do Terceiro Mundo, inclusive no Brasil, em estudos epidemiológicos de prevalência da doença periodontal. Devido a amplos questionamentos quanto à sua aplicação em pesquisa epidemiológica, por subestimar a condição periodontal em população adulta e por superestimar a condição periodontal em população jovem, modificações foram introduzidas de modo que se tivesse um sistema de exame periodontal mais sensível às alterações inflamatórias das estruturas periodontais, dispensando tomadas radiográficas, nem sempre possíveis ou praticáveis em pesquisa epidemiológica. Este, após readequações, originou um sistema de mensuração atualmente recomendados pela OMS ${ }^{75}$, composto de 2 índices: Índice Periodontal Comunitário (IPC) e Perda de Inserção periodontal (PI). 


\subsection{DIFICULDADES ENCONTRADAS}

No presente estudo, planejou-se examinar 100 pacientes de cada grupo, perfazendo um total de 200 exames. Todavia, dificuldades de recrutamento dos pacientes cardiopatas com número mínimo de 20 dentes funcionais e ausência de tempo hábil para emparelhamento por idade com os pacientes não-cardiopatas, alteraram o planejamento inicial, quanto ao tamanho e composição da amostra.

No primeiro contato estabelecido com os pacientes de ambos os ambulatórios, quando se obtiveram dados preliminares à coleta das informações específicas do estudo, os resultados surpreenderam, pois, dado ao grande volume de pacientes que comparecem à rotina dos ambulatórios, esperava-se selecionar com presteza os componentes da amostra prevista.

No entanto, no grupo de pacientes cardiopatas deparou-se com a grande freqüência de pacientes com insuficiente número de dentes para se investigar a doença periodontal em adequado número de sítios, representativos dos vários sextantes da boca. Devido ao fato de se ter estabelecido como critério de seleção um número mínimo de 20 dentes funcionais, o tamanho amostral pretendido não foi conseguido, uma vez que no Ambulatório de Cardiopatia Isquêmica do HCFMRPUSP, dos 480 pacientes avaliados preliminarmente, apenas $80(16,7 \%)$ foram considerados elegíveis por contemplar este critério de inclusão. Desses, 22 pacientes foram excluídos por apresentar um ou mais dos critérios de exclusão, resultando uma amostra final de 58 pacientes, ou seja, 12,1\% da população avaliada inicialmente. Foram necessárias 21 semanas para se atingir o tamanho amostral final deste grupo.

Entre os pacientes não-cardiopatas, o grande volume de consultas da rotina do Ambulatório de Hepatites do HCFMRP-USP, selecionado pela disponibilidade para a coleta de dados do grupo controle, também predizia uma coleta ágil. No entanto, a distribuição segundo a idade permitiu observar que os pacientes da rotina deste ambulatório são significativamente mais jovens que os pacientes cardiopatas. Dessa maneira, o emparelhamento de idade pretendido com o grupo teste ficou impossibilitado. Foram avaliados preliminarmente 154 pacientes, sendo 71 considerados elegíveis $(46,1 \%)$, e 62 pacientes $(40,2 \%)$ incluídos no estudo. Foram 
necessárias 8 semanas para se atingir o tamanho amostral final deste grupo. Ambos os prazos excederam o planejamento inicial.

Observaram-se grandes diferenças nas idades dos pacientes que compuseram os dois grupos estudados. No grupo de pacientes cardiopatas a média de idade foi 53 anos nos homens e nas mulheres, e a mediana 53 anos nos homens e 55 anos nas mulheres. No grupo de pacientes não-cardiopatas, a média e a mediana de idade foram respectivamente 40 e 39 anos nos homens e 37 e 35 anos nas mulheres. Essa discrepância de idade limita consideravelmente a comparação dos resultados obtidos na avaliação periodontal entre os dois grupos.

Outro fato que por um certo tempo dificultou a obtenção das informações foi a falta de um local apropriado para que se procedesse o exame bucal. Essa limitação acabou sendo contornada com a utilização das dependências do Núcleo de Vigilância Epidemiológica do Departamento de Medicina Social da FMRP-USP. 


\subsection{VARIÁVEIS GERAIS}

Algumas variáveis, que se denominou como "gerais", pela sua importância no processo saúde-doença periodontal, foram investigadas em ambos os grupos por uma única entrevistadora. Pelas evidências hoje disponíveis na literatura científica, algumas dessas variáveis são consideradas fatores de risco (fumo, diabetes), enquanto outras são prováveis fatores de risco (higiene bucal, nível socioeconômico) às doenças periodontais. Esta pesquisa também poderia permitir a identificação dos agentes educadores, do grau de conhecimento da doença periodontal e outras patologias bucais, tanto quanto de algumas práticas de saúde dos participantes do estudo.

Com relação ao grau de escolaridade, pressupôs-se que esta variável tenha associação positiva com acesso tanto a informações quanto a serviços de saúde bucal, além de ser indicador do nível socioeconômico dos participantes. Segundo ela, observou-se que 50,0\% dos pacientes cardiopatas e 22,6\% dos pacientes nãocardiopatas não possuíam educação básica (não estudaram ou têm o $1^{\circ}$ grau incompleto). Se pudermos considerar como melhor condição de acesso a informações e a serviços de saúde bucal estar na categoria "superior completo", os pacientes cardiopatas estão em desvantagem em relação aos pacientes nãocardiopatas $(15,5 \%$ e $21,0 \%$, respectivamente). Se associarmos ainda a idade mais elevada deste grupo, têm-se um risco adicional para a doença periodontal.

Quanto ao tabagismo, pode-se afirmar que existe uma relação entre o hábito de fumar e as doenças periodontais (Genco, $1996{ }^{40}$; Harber, $1993{ }^{43}$; Harber \& Kent, $1992^{44}$; Kinane \& Radvar, $1997^{49}$; Rivera-Hidalgo, $1986^{88}$; Stoltenberg et al., 1993 ${ }^{97}$; Zambom et al. $1996^{105}$ ). Os percentuais de fumantes entre os pacientes cardiopatas e os não-cardiopatas foram de $10,4 \%$ e $33,9 \%$, respectivamente ( $\mathrm{p}<$ 0,01). De ex-fumantes, os percentuais foram de $58,6 \%$ e $22,6 \%$, respectivamente ( $\mathrm{p}<$ 0,0001). Talvez a observação de menor número de fumantes e maior de pessoas que abandonaram o tabagismo, no grupo de pacientes cardiopatas, ocorra em respeito às recomendações certamente fornecidas pela equipe médica, mediante a comprovação de que o fumo é fator de risco importante à isquemia e ao infarto do miocárdio. 
Genco (1996) ${ }^{40}$ observou que entre não fumantes $56 \%$ apresentavam saúde e 7,5\% doença periodontal grave; entre fumantes pesados apenas 9,2\% apresentavam saúde periodontal. Este autor afirma que o tabagismo é o mais importante fator de risco às doenças periodontais e que esta prática aumenta de 2 a 7 vezes este risco, dependendo da quantidade fumada. Nesta pesquisa observou-se que $100 \%$ (40) dos pacientes cardiopatas fumantes e ex-fumantes apresentavam doença periodontal moderada ou grave; dos que relataram nunca ter praticado tabagismo, 16,7\% apresentavam doença leve e $83,3 \%$ doença moderada e grave. Entre os pacientes nãocardiopatas fumantes e ex-fumantes, $37,1 \%$ (13/35) apresentavam doença periodontal moderada ou grave, 62,9\% apresentavam doença leve; entre os que relataram nunca ter praticado tabagismo, 40,7\% apresentavam saúde, 29,6\% apresentavam doença leve e $29,6 \%$ doença moderada ou grave.

Quanto ao acesso à orientação sobre métodos e dispositivos de higiene bucal, as pequenas diferenças observadas entre os grupos (65,5\% entre cardiopatas e $67,7 \%$ entre não-cardiopatas) demonstra que percentual elevado de pessoas dos dois grupos tiveram acesso a informações, muito embora não se possa proceder ao julgamento da qualidade destas informações. O cirurgião-dentista e a família representaram a maior fonte de acesso a informações.

$\mathrm{O}$ achado de que aproximadamente um terço dos participantes de cada um dos grupos não havia recebido informações relativas à higiene bucal mostra que a odontologia necessita praticar de modo abrangente seu papel educativo, e, através de seus órgãos representativos, proceder a uma ampla e contínua prática de educação em saúde bucal. Políticas públicas de saúde deveriam também incorporar conceitos de promoção e prevenção em saúde bucal, e do acesso e importância de exames bucais preventivos periódicos.

De acordo com Axelsson \& Lindhe (1981) 9, 10, 11, o controle do biofilme dental é amplamente reconhecido como parte fundamental dos autocuidados necessários para a manutenção da saúde bucal, fazendo parte inclusive das estratégias de tratamento periodontal. Entretanto, com relação aos hábitos e acessórios de higiene bucal, neste estudo podem ser considerados como fatores ou viéses de confusão por serem referidos pelos participantes, podendo não refletir a verdade 
absoluta, associado ao fato de que o desempenho pode não produzir a eficiência planejada para a remoção do biofilme dental. Devido a limitações operacionais, as informações relacionadas às variáveis relativas à higiene bucal foram coletadas através de perguntas simples e diretas, não se utilizando critérios ou índices clínicos de higiene bucal, nem análises microbianas que permitissem julgamento da especificidade do biofilme dental.

Em relação aos cuidados de higiene bucal, como prática e número diário de escovações, tipo de escova (dura, média e macia), tempo aproximado gasto na escovação, troca da escova dental, uso individual ou familiar/coletivo da escova dental, uso de fio/fita dental, uso de creme dental, uso e tipo de enxagüatório bucal e uso e tipo de acessório de higiene bucal, as pequenas diferenças observadas entre os grupos não têm significância estatística.

Tempo de higiene bucal compatível com bons resultados para a remoção do biofilme foi observado em $1,7 \%$ dos pacientes cardiopatas e $1,6 \%$ dos nãocardiopatas; tempo medianamente aceitável (4 a 9 minutos) foi observado em 12,1\% dos pacientes cardiopatas e $21,0 \%$ dos não-cardiopatas; tempo insuficiente (3 minutos ou menos) foi observado em $86,2 \%$ dos pacientes cardiopatas e $77,4 \%$ dos não-cardiopatas.

Quanto ao tipo de escova, entre os pacientes cardiopatas 58,6\% usam escova dura ou média e 41,4\% usam escova macia. Entre os não-cardiopatas 53,2\% usam escova dura ou média e 46,8\% usam escova macia.

Quanto ao consumo de álcool, o menor percentual de consumidores entre os pacientes não-cardiopatas $(24,2 \%$ contra $44,8 \%$; $\mathrm{p}<0,02)$ pode ser explicado pelo fato de que, por apresentarem alterações hepáticas próprias das hepatites, houve recomendação da equipe médica para eliminação do consumo de álcool. Em assim sendo, surpreende encontrar entre os pacientes não-cardiopatas um percentual ainda muito elevado de consumidores de álcool. Esta variável foi investigada devido a suspeita que os usuários diários ou de grande quantidade de álcool poderiam negligenciar nos autocuidados com a higiene bucal. 
O diabetes é considerado fator de risco à doença periodontal e está relacionado à capacidade de resposta do hospedeiro aos desafios impostos pela presença da infecção pelos patógenos periodontopatogênicos. Papapanou (1996) ${ }^{78}$ observou que pacientes diabéticos têm probabilidade três vezes maior de apresentarem perda de inserção periodontal. Nos grupos estudados, observou-se que 29,3\% dos pacientes cardiopatas e 1,6\% dos pacientes não-cardiopatas têm diabetes, diferença altamente significante $(\mathrm{p}<0,0001)$.

Quanto à hipertensão arterial, 34,5\% dos pacientes cardiopatas e 8,1\% dos pacientes não-cardiopatas relataram história médica de sua presença, diferença esta com significância estatística ( $p<0,001)$. Isto possivelmente seja decorrente da idade mais elevada dos pacientes cardiopatas e a hipertensão ser uma condição de risco para o desenvolvimento de cardiopatias isquêmicas.

Quanto à histórico de acidente vascular cerebral (AVC) prévio, considerou-se que este poderia produzir seqüelas que implicassem em redução da capacidade motora ou mecânica para a prática de hábitos saudáveis de higiene bucal. Observouse antecedente de AVC em 3,4\% dos pacientes cardiopatas e em nenhum paciente não-cardiopata. Esta observação talvez possa ser atribuída à idade mais elevada e maior presença de hipertensão arterial entre os pacientes cardiopatas. Morrison et al. (1999) ${ }^{70}$, Ross (1999) ${ }^{90}$ e Wu et al., $2000{ }^{104}$ relataram que a doença periodontal é fator de risco para AVC.

Quanto ao uso contínuo de medicação, a ocorrência de $100 \%$ entre pacientes cardiopatas e somente $9,7 \%$ entre pacientes não-cardiopatas pode ser atribuído ao uso de medicamentos como prevenção secundária na doença coronariana e à persistência de seqüelas e de fatores que levaram ao episódio de isquemia e/ou infarto do miocárdio.

Com relação ao conhecimento prévio sobre a existência de doença periodontal, se esta variável de algum modo pudesse representar preocupação e busca por procedimentos preventivos e terapêuticos, os percentuais de pessoas que obtiveram informações de profissionais qualificados, e, por conseguinte, possivelmente informações com maior fidedignidade, foram de $25,9 \%$ entre os 
pacientes cardiopatas e 32,3\% entre os pacientes não-cardiopatas. Este fato ilustra que pequena proporção da população dos dois grupos estudados tem acesso a orientações e serviços de saúde bucal.

Quanto aos acessos e indicações de Terapia Periodontal Básica, Terapia Periodontal Complexa e Terapia Periodontal de Manutenção, apesar da pequena diferença entre os grupos, isto não garante maior qualidade das práticas para conquista da saúde bucal, e talvez seja mais reflexo do melhor conhecimento da necessidade de exames rotineiros e da melhor condição de saúde geral para tolerar terapia odontológica entre os pacientes não-cardiopatas. Este achado adiciona uma preocupação, pois, o paciente cardiopata desconhecendo sua condição de portador da doença periodontal não procura resolvê-la; na falta de tratamento a doença se agrava, provocando a perda dos dentes e conseqüente mutilação bucal, comprometendo mais a saúde geral desses indivíduos.

Quanto aos problemas ou queixas bucais relatados, as diferenças nos percentuais de pessoas com queixas e também quanto ao tipo de queixa, talvez sejam reflexo da idade mais elevada e maior experiência nas diversas patologias bucais, incluindo-se aí a cárie dentária e doenças periodontais e suas seqüelas, entre os pacientes cardiopatas $(84,5 \%$ contra $62,9 \%$; $<<0,01)$. 


\subsection{VARIÁVEIS ESPECÍFICAS}

As variáveis mais relacionadas às doenças periodontais propriamente ditas e passíveis de observação durante inspeção visual e sondagem periodontal foram agrupadas neste subtítulo.

$\mathrm{Na}$ fase de recrutamento dos participantes, as grandes diferenças observadas em relação ao número de dentes funcionais entre pacientes cardiopatas e nãocardiopatas, possivelmente grande parte esteja atribuída às diferenças de idade observadas entre os grupos. Para a composição dos grupos, mesmo com o critério de seleção da amostra sendo um número mínimo de 20 dentes funcionais, que permitiria a investigação periodontal em diferentes áreas da boca, obteve-se média de dentes diferentes em pacientes cardiopatas (25) e não-cardiopatas (27). Em ambos os grupos pode-se considerar que seus representantes apresentavam, na fase de coleta de dados, a capacidade funcional aparentemente preservada, fato que não se repetiria após o exame periodontal, quando em muitos pacientes cardiopatas foi detectada a necessidade de exodontia dos dentes, com graves perdas de inserção periodontal e mobilidade dentária incapacitante.

No tocante à observação de necessidades bucais, verificou-se uma grande freqüência delas em ambos os grupos (100\% entre os pacientes cardiopatas e 82,3\% entre os pacientes não-cardiopatas). Quanto às necessidades segundo a área ou especialidade odontológica, observaram-se grandes diferenças entre os grupos no tocante ao tipo de necessidades. Isto talvez esteja relacionado a diferentes fatores, tais como: idade mais elevada, menor acesso a serviços, estabelecimento de prioridades (quando há problema de saúde que implique em alto risco de vida, algum outro problema que aparentemente não comprometa a vida passa a ser menos prioritário), menor acesso a informações educativas/preventivas, demanda por procedimentos de reabilitação bucal entre adultos e idosos, grande freqüência de uso de peças protéticas inadequadas e menor acesso a serviços rotineiros que controlam as condições de saúde das estruturas bucais e da qualidade das próteses, a não valorização dos dentes. 
Talvez pela idade mais elevada, associada a menor número de dentes em boas condições, menor acesso a serviços preventivos no passado e desconhecimento da necessidade de controle profissional periódico, observou-se, entre os pacientes cardiopatas, percentuais mais elevados de necessidade de reabilitação protética $(41,4 \%$ contra $17,7 \% ; \mathrm{p}<0,01)$, e, por conseguinte, maior demanda por orientações de auto-exame e exames profissionais rotineiros para prevenção do câncer bucal $(62,1 \%$ contra $9,7 \% ; \mathrm{p}<0,0001)$.

Não se observou diferença de conhecimento da necessidade de troca periódica de peças protéticas entre os componentes dos grupos. Foi comum no relato dos portadores de próteses de ambos os grupos, o desconhecimento da importância da substituição, em especial de próteses totais, que possuem dentes com potencial de desgaste maior se comparado a dentes naturais e não confeccionados em resina acrílica, tanto quanto o desconhecimento da reabsorção do rebordo alveolar que favorece o deslocamento da prótese e o traumatismo constante dos tecidos moles, com maior risco ao desenvolvimento de câncer bucal.

Segundo Pinto (2000) ${ }^{83}$, os fatores externos mais associados com a gênese do câncer bucal são o tabagismo, alcoolismo, exposição à radiação solar, fatores ocupacionais, má higiene bucal, irritação mecânica crônica da mucosa bucal por próteses mal ajustadas ou com câmara de sucção e por dentes fraturados. A associação dos fatores próprios do hospedeiro com os externos, aliado ao tempo de exposição, constitui condição básica para iniciar o processo maligno na boca.

Quanto à presença e tipo de fatores de retenção de biofilme dental (cárie e cálculo dental, restauração/prótese insatisfatória e apinhamento dental), as diferenças observadas entre os componentes dos grupos talvez ocorram pela idade menos elevada e maior acesso a orientações e tratamento entre os pacientes não-cardiopatas.

Quanto ao achados do Índice Periodontal Comunitário (IPC), grandes diferenças foram observadas. Houve predomínio de escores indicativos de saúde $(32,0 \%)$ ou de menor gravidade da doença periodontal $(48,4 \%)$ entre os pacientes não-cardiopatas e de escores indicativos de maior gravidade $(79,3 \%)$ entre os pacientes cardiopatas. Este fato pode ser atribuído a fatores sistêmicos comuns às 
doenças cardiovasculares e periodontais, à maior idade observada entre os componentes deste grupo, à falta de acesso às diferentes modalidades de terapia periodontal, à não priorização de outras terapias que não as relacionadas com as alterações isquêmicas e ao temor dos pacientes e dos profissionais de odontologia no tratamento de portadores de cardiopatias e usuários de drogas anticoagulantes e antiagregantes. As associações feitas através de estudos epidemiológicos sobre as doenças periodontais e a idade, demonstraram que esta tem sido fortemente correlacionadas às periodontites. Obviamente que elas não sejam uma consequiência da idade, no entanto, indivíduos que manifestam estágios iniciais da doença periodontal sem adequado tratamento, poderão apresentar após decorrido algum tempo, quadros graves da doença.

Quanto à Perda de Inserção (PI) periodontal, as diferenças foram significativas. Houve predomínio de sextantes com maiores graus de perda de inserção entre os pacientes cardiopatas $(61,5 \%$ contra $7,5 \% ; p<0,0001)$. Este fato pode ser atribuído a fatores sistêmicos comuns às doenças cardiovasculares e periodontais, à idade mais elevada dos componentes deste grupo, à falta de acesso a tratamento periodontal adequado e ao desconhecimento da condição de portador de patologia periodontal.

Na análise das Tabelas 20 e 21, não se observou diferenças de gravidade das doenças periodontais de acordo com os grupos etários. A falta de correlação entre idade e gravidade da doença pode ser atribuída ao pequeno tamanho amostral em ambos os grupos. Autores como Lindhe et al. (1983) ${ }^{51}$, Lindhe \& Nyman (1988) ${ }^{52}$, Löe et al. (1986) $)^{56}$, Baelum et al. (1996) ${ }^{13}$ afirmam que esta correlação é real para quadros de periodontite em indivíduos sem adequado tratamento de manutenção periodontal.

A despeito do caráter desumano e não compatível com as boas práticas do exercício da odontologia, o estado de abandono periodontal observado nos pacientes cardiopatas permitiria o absurdo de incluí-los em estudo regional de história natural da doença periodontal, em grupo de risco sem acesso a terapia, porém com procedimentos individuais de higiene bucal. 
Quanto à necessidade de tratamento periodontal, grandes diferenças foram observadas em relação à complexidade de tratamento exigida, com grande percentual de pacientes cardiopatas $(79,3 \%)$ necessitando de tratamento periodontal de maior complexidade, com diagnóstico periodontal mais difícil e com procedimentos normalmente não realizados por clínicos gerais da área odontológica. Entre os pacientes não-cardiopatas houve predomínio de necessidade de tratamento periodontal menos complexo $(48,4 \%)$, passíveis de diagnóstico e tratamento por clínicos gerais, e ausência de necessidade de tratamento periodontal (17,7\%).

No processo de formação básica dos estudantes de odontologia, provavelmente não é dada adequada importância aos conceitos da doença periodontal, bem como de suas especificidades e dinâmica. Esta possível lacuna na formação profissional da odontologia faz com que o diagnóstico e tratamento de bolsa periodontal fuja ao domínio do clínico geral. Como conseqüência, mesmo o paciente que rotineiramente procura tratamento é colocado na condição de desconhecer suas necessidades em relação à saúde periodontal, assim como às possibilidades de recuperar-se e manter-se saudável.

Muitos dos achados do estudo talvez sejam reflexo do maior acesso a orientações e serviços de manutenção de saúde bucal entre os pacientes nãocardiopatas. No entanto, os achados relacionados aos sinais de doença periodontal, atual e pregressa, possivelmente estejam relacionados a fatores sistêmicos comuns às doenças cardiovasculares e periodontais e à idade mais elevada dos pacientes cardiopatas.

Pelos achados deste estudo, conclui-se que é fundamental a criação de meios que melhor orientem os pacientes para os cuidados necessários na conquista da saúde bucal.

No âmbito do HCFMRP-USP, impõe-se a inclusão de procedimentos de diagnóstico e tratamento sistemático das doenças periodontais, viabilizando aos pacientes necessitados uma rápida e efetiva atenção à saúde bucal. 


\section{CONCLUSÕES}

Anteriormente ao relato das conclusões desta pesquisa deve-se reforçar que as doenças periodontais são tempo-dependentes e que, dado as diferenças nas idades observadas nos dois grupos estudados, deve-se ter cautela na análise dos resultados obtidos. No entanto, respeitando-se a discrepância na composição etária e o não emparelhamento dos grupos, os resultados obtidos com ela permitiram as seguintes conclusões:

- $\quad$ as doenças periodontais mostraram alta prevalência em ambos os grupos estudados, atingindo $100 \%$ dos pacientes cardiopatas e $82,3 \%$ dos pacientes nãocardiopatas;

- $\quad$ saúde periodontal foi observada em $1,1 \%$ dos sextantes dos pacientes cardiopatas e $32,0 \%$ dos sextantes de pacientes não-cardiopatas;

- indivíduos totalmente saudáveis foram observados somente no grupo de nãocardiopatas, correspondendo a 17,7\% (11) pacientes;

- $\quad$ as doenças periodontais foram de maior gravidade nos pacientes cardiopatas portadores de doença isquêmica coronariana aterosclerótica, sendo que as formas mais graves com presença de bolsas periodontias $\geq 6 \mathrm{~mm}$, atingiram 48,9\% dos sextantes desses pacientes e 4,6\% dos sextantes de pacientes não-cardiopatas;

- $\quad$ sua forma mais grave, com presença de bolsas periodontias $\geq 6 \mathrm{~mm}$, por indivíduo, também foram de maior gravidade nos portadores de doença isquêmica coronariana aterosclerótica, atingindo 79,3\% (46) dos pacientes cardiopatas e 9,7\% (6) dos não-cardiopatas 
- maiores necessidades de tratamento periodontal, inclusive com a inclusão de especialistas em periodontia, foram observadas no grupo de pacientes cardiopatas, tanto na análise por indivíduo como por sextante;

- $\quad$ as formas moderadas da doença periodontal, com bolsas periodontais entre 4 a 5mm, atingiram 25,3\% dos sextantes de pacientes cardiopatas e 15,5\% dos sextantes de pacientes não-cardiopatas;

- cálculo dentário foi detectado em $17,2 \%$ dos sextantes dos pacientes cardiopatas e 33,1\% dos sextantes de pacientes não-cardiopatas;

- $\quad$ sangramento à sondagem foi observado em 4,6\% dos sextantes dos pacientes cardiopatas e $14,8 \%$ dos sextantes de pacientes não-cardiopatas;

- $\quad$ informações e cuidados em saúde bucal não foram significativamente diferentes nos grupos estudados;

- novos estudos devem ser conduzidos, com amostra maior e adequado emparelhamento por idade, para se estabelecer com mais precisão a real condição periodontal. 


\section{COMENTÁRIOS FINAIS}

A maior gravidade da doença periodontal nos pacientes cardiopatas sugere que fatores sistêmicos podem estar envolvidos de forma simultânea na origem das duas doenças.

A alta prevalência das distintas formas de doença periodontal em ambos os grupos, evidencia a necessidade de desenvolver estratégias de atenção em saúde bucal. Dentre essas estratégias pode-se identificar:

1 - estratégias preventivas para grandes contingentes da população, buscando a redução do biofilme dental e, por conseguinte, das doenças periodontais. Adequadas posturas em relação à higiene bucal certamente conduzem a melhoras no padrão de saúde periodontal, permitindo reduzir o número de extrações dentárias e demandas por reabilitação bucal, onerosas para as pessoas e instituições financiadoras. Como parte desta estratégia de educação para a saúde bucal, incentivar a disponibilização de artigos ou acessórios de higiene com maior qualidade e a preços acessíveis, proporcionar ensinamentos compatíveis com saúde periodontal e com melhoria das condições de vida no ambiente social (higiene geral, alimentação saudável).

2 - estratégia de atenção periodontal precoce, com vistas a proporcionar tratamento às pessoas com doença em estágios iniciais (sangramento gengival e cálculo dentário). Isto permitiria evitar a instalação das formas graves de doença e reduzir futuras perdas dentárias. Vale ressaltar a importância de conscientizar os pacientes de que o tratamento não leva à cura permanente, fato somente possível quando todos os fatores causais são controlados ou eliminados e quando as estratégias de higiene bucal individual são eficazes. 
3 - estratégias para grupos de pessoas com risco elevado de desenvolver doenças periodontais. Poderiam ser incluídos neste grupo, pessoas fumantes, com baixa renda, com dificuldades de modificar hábitos inadequados de remoção do biofilme dental, bem como as pessoas portadoras de HIV, com diabetes, com deficiências psicomotoras, com cardiopatias isquêmicas. 
ANEXOS 


\section{ANEXO A \\ FORMULÁRIO DE COLETA DE DADOS}

1. Clínica de Origem:

2. DATA DO EXAME /2002

3. DADOS PESSOAIS

3.1 Prontuário $\mathrm{n}^{\circ}$ Nome

3.2 Idade !____ ! Data de Nascimento

3.3 Sexo !__ ! 1=masc; $2=$ fem

3.4 Procedência: Município

Estado

3.5 Ocupação !__ ! (ver tabela de ocupação)

3.6 Cor da pele ! _ ! 1=branco; 2=negro; $3=$ pardo; 4=amarelo

3.7 Escolaridade ! _ ! 1 1=não estudou; $2=1^{\circ} \mathrm{G}$ incompleto; $3=1^{\circ} \mathrm{G}$ completo; $4=2^{\circ} \mathrm{G}$ incompleto; 5=2 $\mathrm{O}$ G completo; 6=superior incompleto; 7=superior completo; $8=$ não sabe/não lembra.

3.8 Diagnóstico cardiológico !__ !___________ ( ver tabela CID 10) para o grupo de cardiopatas OU a pergunta "Algum médico já lhe disse que você tem ou teve ataque cardíaco, angina de peito ou doença coronariana?" para o grupo de não-cardiopatas !__ ! 1=sim; 2=não; se SIM, término da entrevista.

3.9 Tabagismo !__ ! 1=nunca fumou; 2=fumante de menos 10 cigarros ao dia; $3=$ fumante de 10 a 20 cigarros ao dia; 4=fumante de 20 a 30 cigarros ao dia; $5=$ fumante de mais de 30 cigarros ao dia; $6=$ ex-fumante.

Para fumante e ex-fumante:

Tempo de fumo !__ ! _ ! (em anos)

3.10 Hábitos de higiene bucal

3.10.1 Foi orientado sobre higiene bucal !__ ! 1=sim; 2=não

3.10.2 Se orientado, por quem !__!_! 1=dentista; 2=família; 3=na escola ou outra instituição; 4=leu a respeito; 5=outro

3.10.3 Pratica a escovação dos dentes diariamente?!__ ! 1=sim; 2=não

3.10.4 Número de escovações ao dia !__ ! 1=1 vez; $2=2$ vezes; $3=3$ vezes; $4=4$ ou mais vezes. 
3.10.5 Tipo de escova ! _ ! 1=dura; 2=média; 3= macia ou extra macia; 4=não sabe

3.10.6 Tempo aproximado gasto com a escovação !____! (em minutos; escovação que o paciente considera a mais importante do dia)

3.10.7 Troca da escova !__!____ (em dias) OU somente troca quando 1=perde; 2 =quebra; $3=$ pelo aspecto das cerdas; 4=não sabe

3.10.8 Segundo o uso da escova, ela é !__ ! 1=individual; 2=familiar/coletiva

3.10.9 Fio/fita dental ! _ _ 1=não usa; $2=$ usa às vezes; $3=$ usa diariamente

3.10.10 Creme dental !__ ! _ ! 1=antitártaro; 2=com triclosan; 3=comum; 4=outro; $5=$ não usa; $6=$ variados

3.10.11 Enxagüatório bucal !__ ! 1=não usa; 2=usa às vezes; 3=usa diariamente. Se usa, qual(is)? !__!_ ! ! _ ! 1 1=clorexidina; 2=listerine; 3=triclosan; 4=cetilperidínio; 5=própolis; 6=água oxigenada; 7=flúor; 8=solução caseira; 9=outro;

3.10.12 Usa outro tipo de acessório? !_! 1=sim; 2=não. Qual(is)? !_ ! _ ! _ ! ! ! ! _ ! 1=escova interproximal; 2=escova bitufo; 3=waterpik; 4=massageadores gengivais; 5=limpador de língua; 6=palito; $7=$ outro

3.10.13 Consumo de álcool ! _ ! 1=todos os dias; $2=5$ a 6 dias por semana; $3=3$ a 4 dias por semana; $4=1$ a 2 dias por semana; $5=3$ a 4 dias ao mês; $6=1$ a 2 dias ao mês; $7=$ menos que 1 dia ao mês; $8=$ nunca consumiu; 9=consumiu no passado

3.11 Doenças de interesse à periodontia !__ ! 1=sim; 2=não. Se sim, qual (is?) !__ ! ! _ ! _ ! 1 1=Diabetes; 2=AVC; 3=HA; 4=outra(s); especificar abaixo.

3.12 Uso contínuo de medicação !__! 1=sim; 2=não. Se sim, qual(is)? !_!_!__! 1=anticoagulante; 2=antiagregante plaquetário; 3=fenitoína; 4=outra; $5=$ não sabe

3.13 Conhecimento prévio sobre doença periodontal !__! ! 1=não sabe que existe; 2=sabe porque alguém da família ou de suas relações tem; 3=sabe porque recebeu orientações específicas/profissionais; 4=sabe porque leu a respeito; $5=$ acha que tem este tipo de problema; $6=$ acha que isto é invenção; $7=$ outro. 
3.14 Terapia Periodontal Básica !__ ! 1=não fez; 2=fez ou faz eventualmente; $3=$ faz rotineiramente; $4=$ outro

3.15 Terapia Periodontal Complexa !__ ! 1=nunca indicada; 2=indicada e não realizada; $3=$ realizada conforme indicação; 4=outro

3.16 Terapia Periodontal de Manutenção !_! ! 1=nunca fez/nunca indicada; $2=$ indicada e não realizada; $3=$ indicada e feita segundo prescrito; $4=$ outro

3.17 Queixas bucais: !__! 1=sim; 2=não. Se sim, qual(is)?

1. DOR ! _ ! 1=sim; $2=$ não

2. CÁRIE! _ ! 1=sim; 2=não

3. DOENÇA PERIODONTAL !__ ! 1=sim; 2=não

4. LESÕES DE TECIDOS MOLES !__ ! 1=sim; 2=não

5. ESTÉTICA ! _ ! 1=sim; $2=$ não

6. PRÓTESE !__ ! 1=sim; $2=$ não

7. EDENTULISMO !__ ! 1=sim; $2=$ não

8. FONÉTICA !__ ! 1=sim; $2=$ não

9. HÁBITO PARAFUNCIONAL (bruxismo/apertamento/roer unha e outros objetos) !__ ! 1=sim; 2=não

10. SENSIBILIDADE !__ ! 1=sim; $2=$ não

11. MALOCLUSÃO!__! 1=sim; 2=não

12. $\operatorname{OUTRA}(\mathrm{S}) ! \ldots ! 1=\operatorname{sim} ; 2=$ não 
4. EXAME BUCAL

4.1 Total de dentes presentes na boca!_____!

Por sextante

\begin{tabular}{|l|l|l|}
\hline SD & AS & SE \\
\hline ID & IA & IE \\
\hline
\end{tabular}

4.2 Diagnóstico periodontal provável!__ ! (ver tabela da AAP, 1999)

4.3 Fatores de retenção de biofilme dental !__! 1=sim; 2=não. Se sim, qual(is) !_!_!__!_! 1=cárie; 2=cálculo; 3=restauração/prótese insatisfatória; $4=$ outro

5. ÍNDICE PERIODONTAL COMUNITÁRIO

\begin{tabular}{|l|l|l|}
\hline $17 / 16$ & 11 & $26 / 27$ \\
\hline $47 / 46$ & 31 & $36 / 37$ \\
\hline
\end{tabular}

$0=$ hígido; $1=$ =sangramento; $2=$ =álculo; $3=$ bolsa $4-5 \mathrm{~mm}$; $4=$ bolsa $\geq 6 \mathrm{~mm} ; \mathrm{X}=$ excluído; $9=$ não registrado

6. PERDA DE INSERÇÃO

\begin{tabular}{|l|l|l|}
\hline $17 / 16$ & 11 & $26 / 27$ \\
\hline $47 / 46$ & 31 & $36 / 37$ \\
\hline
\end{tabular}

$0=0-3 \mathrm{~mm} ; 1=4-5 \mathrm{~mm}$ (JAC na tarja preta); $2=6-8 \mathrm{~mm}(\mathrm{JAC}$ entre tarja e anel de $8,5 \mathrm{~mm}) ; 3=9-11 \mathrm{~mm}$ (JAC entre os anéis de 8,5 e $11 \mathrm{~mm}) ; 4=12 \mathrm{~mm}$ ou + (JAC além do anel de $11 \mathrm{~mm}$; $X=$ =xcluído; $9=$ não registrado.

7. Necessidades observadas durante o exame bucal, segundo área ou especialidade:

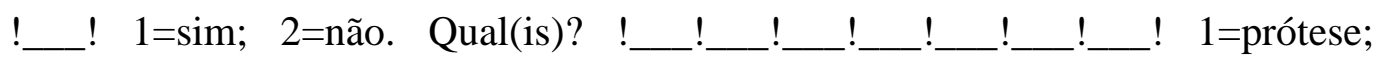
2=periodontia; 3=endodontia; 4=cirurgia/exodontia; 5=educação para prevenção de câncer bucal; $6=$ dentística; $7=$ outras (ortodontia, etc.).

8. Local de exame bucal: !__ ! 1=HCFMRP-USP; $2=$ =consultório particular. 


\section{ANEXO B - Termo de Consentimento}

\section{UNIVERSIDADE DE SÃO PAULO - FACULDADE DE MEDICINA DE RIBEIRÃO PRETO DEPARTAMENTO DE MEDICINA SOCIAL - CURSO DE PÓS-GRADUAÇÃO MESTRADO "SAÚDE NA COMUNIDADE"}

\section{PREVALÊNCIA DAS DOENÇAS PERIODONTAIS EM PACIENTES COM DOENÇA ISQUÊMICA CORONARIANA ATEROSCLERÓTICA, EM HOSPITAL UNIVERSITÂRIO.}

Com esta pesquisa se quer conhecer a freqüência das doenças gengivais em pacientes que tiveram doença coronariana (angina ou infarto do miocárdio), e são atendidos no HC-FMRP-USP. Conhecer a presença das doenças de gengiva permite orientar adequadamente o paciente sobre os cuidados necessários para que conquiste saúde bucal e/ou para não haver agravamento do seu problema cardíaco.

Para que se conheça a presença das doenças gengivais é necessário que um cirurgião-dentista habilitado examine seus dentes e gengiva. Este exame é feito com o uso de um instrumento (sonda) com pequena esfera (bolinha) na ponta, que permite tocar na gengiva ao redor dos dentes sem provocar nenhum dano (machucado), para verificar a presença de sinais da doença de gengiva. $\mathrm{O}$ exame não envolve qualquer risco, porém nos pacientes com inflamação da gengiva poderá ocorrer algum desconforto (dor) e discreto sangramento. Os instrumentos são esterilizados e as medidas de assepsia (limpeza) serão rigorosamente mantidas. Outras informações importantes na condução da pesquisa e na formulação de propostas que melhorem o quadro bucal dos pacientes serão obtidas através de perguntas simples e diretas.

A seleção dos pacientes está sendo feita através de consulta aos prontuários, onde se têm documentada a presença de angina ou o histórico de infarto. As informações serão confidenciais e a identidade do paciente será mantida no mais absoluto sigilo. $\mathrm{O}$ paciente não terá eventuais despesas ou danos imediatos ou tardios decorrentes de sua participação neste estudo, bem como continuará sendo acompanhado e assistido neste hospital, mesmo que não concorde em participar.

Se concordar em participar, a autorização bucal deverá ser por escrito, neste formulário.

Agradecemos sua colaboração.

Prof. Dr. Laércio J. Franco

Orientador

CRM-SP 16.730

Fone: (16) 602.2536
CD Ana Lúcia de Azevedo Barilli

Mestranda

CRO-SP 27.032

Fone: (16) 620.0110

$\mathrm{Eu}$, após ler e entender o propósito da pesquisa acima descrita, concordo em participar da mesma.

Ribeirão Preto, de de 2002. 


\section{REFERÊNCIAS BIBLIOGRÁFICAS}

1. AINAMO, J. Epidemiologia da doença periodontal. In: Lindhe J. Tratado de periodontologia clínica. Rio de Janeiro: Guanabara, 1988. Cap. 2, p. 41-53.

2. AINAMO, J. et al. Development of the World Health Organization (WHO) Community Periodontal Index of Treatment Needs (CPITN). Int. Dent. J., v. 32, p. 281-291, 1982.

3. AINAMO, J. Prevention of periodontal disease in the dental office. Intern. Dental Journal, v. 34, p. 56-61, 1984.

4. ALBANDAR, J. M.; BUISCHI, Y. A. P.; AXELSSON, P. Caries lesions and dental restorations as predisposing factors in the progression of periodontal diseases adolescents - a 3-year longitudinal study. J. Periodontol., v. 66, p. 249254, 1995.

5. ALBANDAR, J.M.; BUISCHI, Y. A. P.; OLIVEIRA, L. B.; AXELSSON, P. Lack of effect of oral hygiene training on periodontal disease progression over 3 years in adolescents. J. Periodontol., v. 66, p. 255-270, 1995.

6. ALLENSPACH-PERZILKA, G. E.; GUGGENHEIM, B. Bacterial invasion of the periodontium: an important factor in the pathogenesis of periodontitis? $\mathbf{J}$. Clin. Periodontol., v. 10, p. 609-617, 1983.

7. ARMitage, G. C. Periodontal disease: diagnosis. In: Annals of Periodontology. Lansdowne (EUA): The American Academy of Periodontology, 1996. V. 1, p. 37-237. 
8. ASIKAINEN, S. Occurrence of Actinobacillus actinomycetemcomitans and Spirochetes in relation to age in localized juvenile periodontitis. J. Periodontol., v. 57 , p. 537-541, 1986.

9. AXELSSON, P.; LINDHE, J. Effect of controlled oral hygiene procedures on caries and periodontal disease in adults - results after 6 years. J. Clin. Periodontol., v. 8, p. 239-248, 1981.

10. AXELSSON, P.; LINDHE, J. The effect of a preventive programme on dental plaque, gingivitis and caries in schoolchildren - Results after one and two years. J. Clin. Periodontol., v. 1, p. 127-138, 1981.

11. AXELSSON, P.; LINDHE, J. The significance of maintenance care in the treatment of periodontal disease. J. Clin. Periodontol., v. 8, p. 281-294, 1981.

12. AXTELIUS, B.; SÖDERFELDT, B.; NILSSON, A.; EDWARDSSON, S.; ATTSTRÖM, R. Therapy-resistant periodontitis: psychosocial characteristics. J. Clin. Periodontol., v. 25, p. 482-491, 1998.

13. BAELUM, V.; CHEN, X.; MANJI, F.; LUAN, W. M.; FEJERSKOV, O. Profiles of destructive periodontal disease in diferent populations. J. Periodont. Res., v. 31, p. 17-27, 1996.

14. BAKDASH, B. Oral hygiene and compliance as risk factors in periodontitis. J. Periodontol., May, p. 539-544, 1994.

15. BALLIEUX, R. E. Impact of mental stress on the immune response. J. Clin. Periodontol., v. 18, p. 427-430, 1991.

16. BECK, J. et al. Periodontal disease and cardiovascular disease. J. Periodontol., v. 67, p. 1123-1137, 1996.

17. BECK, J. Periodontal implications: older adults. In: Annals of Periodontology. Lansdowne (EUA): American Academy of Periodontology, 1996. V. 1, p. 322357. 
18. BECKER, W.; BERG, L.; BECKER, B. E. Untreated periodontal disease: a longitudinal study. J. Periodontol., v. 50, p. 234-244, 1979.

19. BRASIL. Ministério da Saúde. Secretaria Nacional de Programas Especiais de Saúde. Divisão Nacional de Saúde Bucal. Levantamento epidemiológico em saúde bucal; Brasil, zona urbana, 1986. Brasília (DF), 137 p., 1988.

20. BRETZ, W. A. Comportamento do hospedeiro e as doenças periodontais. Rev. APCD, v. 50, p. 428-433, 1996.

21. BROWN, L. J.; GARCIA, R. Utilization of dental services as a risk factor for periodontitis. J. Periodontol., May, p. 551-563, 1994.

22. BUCKLEY, L. A.; CROWLEY, M. J. A longitudinal study of untreated periodontal disease. J. Clin. Periodontol., v. 11, p. 523-530, 1984.

23. CHAMBRONE, L. A. Abordagem preventiva: 14 anos de acompanhamento. Rev. APCD, v. 50, p. 159-163, 1996.

24. CHAPPLE, I. L. C. Periodontal disease diagnosis: current status and future developments. Journal of Dentistry, v. 25, p. 3-15, 1997.

25. CHIAPINOTTO, G. A. Etiologia e prevenção da doença periodontal. In: Pinto, Vitor Gomes. Saúde Bucal Coletiva. $4^{\text {a }}$ edição. São Paulo: Santos, 2000. Cap. 15, p. 429-444.

26. CHRISTERSSON, L. A.; ZAMBON, R. G.; DUNFORD, R, G.; GROSSI, S. G.; GENCO, R. J. Specific subgingival bacteria and diagnosis of gingivitis and periodontitis. J. Dent. Res., v. 68 (Spec Iss), p.1633-1639, 1989.

27. CLARK, N. G.; HIRSCH, R. S. Personal risk factors for generalized periodontitis. J. Clin. Periodontol., v. 22, p. 133-145, 1995.

28. COSterton, J. W. et al. Biofilms, the Customized Microniche. J. Bacteriol., v. 176, p. 2137-2142, 1994. 
29. COSTERTON, J. W. Bacterial Biofilms: A commom Cause of Persistent Infections. Science, v. 284, p. 1318-1322, 1999.

30. COUTINHO, M. S. S. A. et al. Chlamydia pneumoniae and atherosclerosis. Identification of bacterial DNA on the arterial wall. Arq. Bras. Cardiol., v. 74, p. 119-128, 2000.

31. CUNHA, A. C. P.; CHAMBRONE, L. A. Prevalência de gengivite em crianças de um nível social baixo. Rev. Periodontia , v. 7, p. 6-10, 1998.

32. CUNHA, A. C. P.; CHAMBRONE, L. A. Prevalência de gengivite em crianças. Rev. Periodontia, v. 7, p. 1-5, 1998.

33. DELANEY, J. E. Periodontal and soft-tissue abnormalities. In: Johnsen, D. C.; Tinanoff, N. The dental clinics of North America - Dental care for the preschool child. Philadelphia: Saunders Company; October 1995. Cap. 39, p. 837-850.

34. DESTEFANO, F. et al. Dental disease and risk of coronary heart disease and mortality. Brit. Med. J., v. 306, p. 688-701, 1993.

35. DIBART, S. Children, adolescents and periodontal disease. J. Dentistry, v. 25, p. 79-89, 1997.

36. EVANS, C. A. Public health: vision and reality. American Journal of Public Health, v. 86, p. 476-479, 1996.

37. FERREIRA, R. A. Odontologia: essencial para a qualidade de vida. Rev. APCD, v. 51, p. 514-521, 1997.

38. FRARE, S. M.; LIMA, P. A.; ALBARELlO, F. J.; PEDOT, G.; RÉGIO, R. A. S. Terceira idade: quais os problemas bucais existentes? Rev. APCD, v. 51, p. 573576, 1997.

39. GENCO, R. et al. Periodontal disease is a predictor of cardiovascular disease in a native american population. J. Den. Res., v. 76, p. 408, 1997. Resumo 3158. 
40. GENCO, R. Current view of risk factors for periodontal diseases. J. Periodontol., v. 67, p. 1041-1049, 1996.

41. GJERMO, P. Factors influencing the assessment of treatment needs. J. Clin. Periodontol., v. 18, p. 358-361, 1991.

42. GROSSI, S. G.; ZAMBON, J. J.; HO, A. W.; et al. Assesment of risk for periodontal disease. I. Risk indicators for attachment loss. J. Periodontol., v. 65, p. 260-267, 1994.

43. HABER, J. Evidence for cigarette smoking as a major risk factos for periodontitis. J. Periodontol., v. 64, p. 16-23, 1993.

44. HABER, J.; KENT, R. L. Cigarette smoking in a periodontal practice. J. Periodontol., v. 63, p. 100-106, 1992.

45. HANCOK, E. B. Prevention. In: Annals of Periodontology. Lansdowne (EUA): American Academy of Periodontology, 1996. Cap. 1, p.223-255.

46. HERZBERG, M. C.; MEYER, M. W. Dental plaque, platelets and cardiovascular disease. In: Annals Periodontology, 1998. V. 3, p. 151-160.

47. HUGOSON, A.; NORDERYD, O.; SLOTTE, C.; THORSTENSSON, H. Distribution of periodontoal disease in a Swedish adult population 1973, 1983 and 1993. J. Clin. Periodontol., v. 25, p. 542-548, 1998.

48. JOSHIPURA, K. J. et al. Poor oral health and coronary heart disease. J. Dent. Res., v. 75, p. 1631-1636, 1996.

49. KINANE, D. F.; RADVAR, M. The effect of smoking on mechanical and antimicrobial periodontal therapy. J. Periodontol., v. 68, p. 467-472, 1997.

50. LANG, N. P.; MOMBELli, A.; ATTSTRÖM, R. Placa e Cálculo Dentais. In: LINDHE, J. Tratado de Periodontia Clínica e Implantologia Oral. $3^{\mathrm{a}}$ ed. Rio de Janeiro: Guanabara Koogan, 1997. Cap. 3, p. 66-91. 
51. LINDHE, J.; HAFFAJEE, A. D.; SOCRANSKY, S. S. Progression of periodontal disease in adult subjects in the absence of periodontal therapy. $\mathbf{J}$. Clin. Periodontol., v. 10, p. 433-442, 1983.

52. LINDHE, J.; NYMAN, S. Visão Global dos Efeitos da Terapia Periodontal. In: LINDHE, J. Tratado de Periodontologia Clínica. Rio de Janeiro: Guanabara, 1988.. Cap. 24, p. 417-431.

53. LISTGARTEN, M. A. Nature of periodontal disease: pathogenic mechanisms. J. Periodontal. Res., v. 22, p. 172-178, 1987.

54. LiSTGARTEN, M. A.; SCHIFTER, C. C.; LASTER, L. 3-year longitudinal study of the periodontal status of an adult population with gingivitis. J. Clin. Periodontol., v. 12, p. 225-238, 1985.

55. LÖE, H. Periodontal disease as we approach the year 2000. J. Periodontol., May, p. 464-467, 1994.

56. LÖE, H.; ANERUD, A.; BOYSEN, H. E.; MORRISON, E. Natural history of periodontal disease in man: Rapid, moderate and no loss of attachment in SriLankan tea laborers 14 to 46 years of age. J. Clin. Periodontol., v. 13, p. 431440, 1986.

57. LÖE, H.; SILNESS, J. Periodontal disease in pregnancy. I. Prevalence and severity. Acta Odontol. Scand., v. 21, p. 533-551, 1963.

58. LÖE, H.; THEILADE, E.; JENSEN, S. B. Experimental gingivitis en man. J. Periodontol., v. 36, p. 173-187, 1965.

59. LOESCHE, W. J. Periodontal disease as a risk factor for heart disease. Compend. Contin. Educ. Dent., v. 15, p. 976-991, 1995.

60. LOESCHE, W.; POHL, A.; KARAPETOW, F. Plasma lipids and blood glucose in patients with marginal periodontitis. J. Dent. Res., v. 76 (Spec. Issue), p. 408 (Abstr. 3160), 1997. 
61. MARCACCINI, A. M.; SOUZA, P. H. R.; TOLEDO, B. E. C. A influência da idade sobre o periodonto: pacientes geriátricos. Odonto 2000., v. 1, p. 8-12, 1997.

62. MARKKANEN, H.; RAJALA, M.; LAMMI, S.; KARINPÄÄ, A.; HEINONEN, O. P. The need for periodontal treatment in relation to socioeconomic status and health behavior. J. Periodontol., v. 51, p. 408-412, 1980.

63. MATTILA, K. et al. Association between dental health and acute myocardial infarction. Br. Med. J., v. 298, p. 779-782, 1989.

64. MATTILA, K. et al. Dental infection and the risk of coronary events: prospective study of patients with documented coronary artery disease. Clin. Infect. Dis., v. 20, p. 588-592, 1995.

65. MATTILA, K. et al. Dental infections and coronary atherosclerosis. Atherosclerosis, v. 103, p. 205-211, 1993.

66. MEALEY, B. L. Periodontal Implications: Medically Compromissed Patients. In: Annals of Periodontology. Lansdowne (EUA): American Academy of Periodontology, 1996. Cap. 3A, p. 256-321.

67. MEDEIROS, U. V.; CARVALHO, J. C. C. Estudo sobre as condições da saúde bucal da população - Programa comunitário de atenção periodontal. Rev. APCD, v. 44, p. 165-170, 1990.

68. MENDEZ, M. V. et al. An association between periodontal disease and peripheral vascular disease. Am. J. Surg., v. 176, p. 153-157, 1998.

69. MOORE, W. E. C. \& MOORE L. V. H. The bacteria of periodontal diseases. Periodontol. 2000, Copenhagem, v. 5, p. 66-77, 1994.

70. MORRISON, H. I. et al. Periodontal disease and risk of fatal coronary heart and cerebrovascular diseases. J. Cardiovasc. Risk, v. 6, p. 7-11, 1999. 
71. MURRAY, C. J. L.; LOPEZ, A. D. Mortality by cause for eight regions of the world: global burden of disease study. Lancet, v. 349, p. 1269-1276, 1997.

72. NORDERYD, O.; HUGOSON, A. Risk of severe periodontal disease in a Swedish adult population: A cross-sectional study. J. Clin. Periodontol., v. 28, p. 1022-1028, 1998.

73. OFFENBACHER, S. Periodontal Diseases: Pathogenesis. Lansdowne (EUA): Annals of Periodontology, v. 1, n. 1, p. 821-878, November, 1996

74. ONG, M. A.; WANG, H-L.; SMITH, F. N. Interrelationship between periodontics and adult orthodontics. J. Clin. Periodontol., v. 25, p. 271-277, 1998.

75. ORGANIZAÇÃO MUNDIAL DA SAÚDE. Levantamentos Básicos em Saúde Bucal. $4^{a}$ ed. São Paulo: Santos, 1999. 65 p.

76. PAGE, R. The Pathobiology of Periodontal Disease May Affect Systemic Disease: Inversion of a Paradigm. In: Annals Periodontology, 1998. V. 3, p. 108-120.

77. PAGE, R. \& KORNMAM, K. The Patogenesis of Human of Periodontitis. An introduction. Periodontol. 2000, v. 14, p. 9-11, 1997.

78. PAPAPANOU, P. N. Periodontal Diseases: Epidemiology. In: Annals of Periodontology. Lansdowne (EUA): The American Academy of Periodontology, 1996. Cap 1A, p. 1-36.

79. PAPAPANOU, P. N.; BAELUM, V. CPITN and the epidemiology of periodontal disease. Community Dent. Oral Epidemiol., v. 24, p. 367-368, 1996.

80. PAPAPANOU, P. N.; LINDHE, J. Epidemiologia da doença periodontal. In: Lindhe, J. Tratado de Periodontia Clínica e Implantologia Oral. $3^{\text {a }}$ ed. Rio de Janeiro: Guanabara Koogan, 1999. Cap 2, p. 43-65. 
81. PAUNIO, $\mathrm{K}$ et al. Missing teeth in ischaemic heart disease in men aged 45-64 years. Eur. Heart J., v. 14, p. 54-56, 1993.

82. PERSSON, R. E.; PERSSON, G. R.; POWEL, L. V.; KIYAK, H. A. Periodontal effects of a biobehavioral prevention program. J. Clin. Periodontol., v. 25, p. 322-329, 1998.

83. PINTO, V. G. Brasil: uma visão geral em 1995. Atualidade Odontológica, v. XI, p. 27-35, 1995.

84. PINTO, V. G. Saúde Bucal Coletiva. 4ª ed. São Paulo: Santos, 2000. 541p.

85. RAMFJORD, S. P.; ASH, M. M. Classificação, mensuração, epidemiologia e história natural das doenças periodontais. In: Periodontologia e Periodontia: teoria e prática moderna. $1^{\text {a }}$ ed. Michigan: Santos, 1991, p. 31-46.

86. RAMFJORD, S. P.; ASH, M. M. Etiologia das doenças periodontais - defesas do hospedeiro e fatores sistêmicos. In: Periodontologia e Periodontia: teoria e prática moderna. $1^{\text {a }}$ ed. Michigan: Santos, 1991, p. 75-104.

87. RAMFJORD, S. P.; MORRISON, E. C.; BURGETT, F. G.; NISSLE, R. R.; SHICK, R. A.; ZANN, G. J.; KNOWLES, J. W. Oral hygiene and maintenance of periodontal support. J. Peridontol., v. 53, p. 27-30, 1982.

88. RIVERA-HIDALGO, F. Smoking and periodontal disease: review of literature. J. Periodontol., v. 57, p. 617-624, 1986.

89. ROBINSON, P. G.; SHEIHAM, A.; CHALlCOMBE, S. J.; WREN, M. W. D.; ZAKRZEWSHA, J. M. Gingival ulceration in HIV infection. J. Clin. Periodontol., v. 25, p. 270-277, 1998.

90. ROSS, R. Atherosclerosis. An inflammatory disease. New England J. Med., v. 340, p. 115-126, 1999. 
91. SAKKI, T. K.; KNUUTTILA, M. L. E.; ANTTILA, S. S. Lifestyle, gender and occupational status as determinants of dental health behavior. J. Clin. Periodontol., v. 25, p. 566-570, 1998.

92. SCHLUGER, S.; YUODELIS, R. A.; Page, R. C. Epidemiologia das doenças periodontais. In: Periodontia - fenômenos básicos, tratamento e inter-relações oclusais e restauradoras. $1^{\text {a }}$ ed. Rio de Janeiro: Interamericana, 1981. Cap , p. 69-77.

93. SILNESS, J.; LÖE, H. Periodontal disease in pregnancy. II correlation between oral hygiene and periodontal conditions. Acta Odont. Scand., v. 24, p. 747-759, 1964.

94. SLOTS, J. Bacterial specificity in adult periodontitis. J. Clin. Periodontol., v. 13, p. 912-917, 1986.

95. SOCRANSKY, S. S. Microbiology of periodontal disease - present status and future considerations. J. Periodontol., v. 48, p. 497-504, 1977.

96. SÖDERHOLM, G.; NOBRÉUS, N.; ATTSTRÖM, R.; EGELBERG, J. Teaching plaque control - I. A five-visit versus a two-visit program. J. Clin. Periodontol., v. 9, p. 203-213, 1982.

97. STOLTENBERG, J. L. et al. Association between cigarette smoking, bacterial pathogens and periodontal status. J. Periodontol., v. 64, p. 1225-1230, 1993.

98. THE AMERICAN ACADEMY OF PERIODONTOLOGY. Annals of Periodontology. International Workshop for a classification of Periodontal Diseases and Conditions. Chicago: The American Academy of Periodontology, December 1999. V. 4, 112 p.

99. THEILADE, E. The experimental gingivitis studies: the microbiological perspective. J. Dent. Res., v. 75, p. 1434-1438, 1996.

100. UNIVERSIDADE DE SÃO PAULO. Sistema Integrado de Bibliotecas/Centro de Computação de São Carlos. Diretrizes para 
apresentação de Teses e Dissertações à USP: documento eletrônico ou impresso. - São Paulo: SIBi/USP, 2001. 16 p.

101. VAN DYKE, T. E. The role of the host response in periodontal disease progression: implications for future treatment strategies. J. Periodontol., v. 64, p. 792-806, 1993.

102. WESTFELT, E.; RYLANDER, H.; DAHLÉN, G.; LINDHE, J. The effect of supragingival plaque control on the progression of advanced periodontal disease.

J. Clin. Periodontol., v. 25, p. 536-541, 1998.

103. WILlIAMS, R. C.; OFFENBACHER, S. Periodontal medicine: the emergence of a new branch of periodontology. Periodontol. 2000, v. 23, p. 9-12, 2000.

104. WU, T. et al. Periodontal disease and risk of cerebrovascular disease: the first national health and examination survey and its follow-up study. Arch. Intern. Med., v. 160, p. 2749-2755, 2000.

105. ZAMBOM, J. J. et al. Cigarette smoking increases the risk for subgingival infection with periodontal pathogens. J. Periodontol., v. 67, p. 1050-1054, 1996. 